\title{
SARS-CoV-2 and the role of airborne transmission: a
}

\section{systematic review [version 1; peer review: 1 approved with}

\section{reservations, 2 not approved]}

\author{
Carl J. Heneghan (D1), Elizabeth A. Spencer (D1), Jon Brassey (D2, \\ Annette Plüddemann¹, Igho J. Onakpoya', David H. Evans (id), John M. Conly4, \\ Tom Jefferson ${ }^{1}$ \\ ${ }^{1}$ University of Oxford, Oxford, Oxfordshire, UK \\ ${ }^{2}$ Trip Database, Trip, Bristol, UK \\ ${ }^{3}$ Li Ka Shing Institute of Virology and Dept of Medical Microbiology \& Immunology, University of Alberta, Alberta, Canada \\ ${ }^{4}$ University of Calgary and Alberta Health Services, Calgary, Canada
}

V1 First published: 24 Mar 2021, 10:232

https://doi.org/10.12688/f1000research.52091.1

Second version: 06 Sep 2021, 10:232

https://doi.org/10.12688/f1000research.52091.2

Latest published: 19 Oct 2022, 10:232

https://doi.org/10.12688/f1000research.52091.3

\section{Abstract}

Background: Airborne transmission is the spread of an infectious agent caused by the dissemination of droplet nuclei (aerosols) that remain infectious when suspended in the air. We carried out a systematic review to identify, appraise and summarise the evidence from studies of the role of airborne transmission of SARS-CoV-2. Methods: We searched LitCovid, MedRxiv, Google Scholar and the WHO Covid-19 database from 1 February to 20 December 2020 and included studies on airborne transmission. Data were dual extracted and we assessed quality using a modified QUADAS 2 risk of bias tool. Results: We included 67 primary studies and 22 reviews on airborne SARS-CoV-2. Of the 67 primary studies, 53 (79\%) reported data on RTPCR air samples, 12 report cycle threshold values and 18 copies per sample volume. All primary studies were observational and of low quality. The research often lacked standard methods, standard sampling sizes and reporting items. We found 36 descriptions of different air samplers deployed. Of the 42 studies conducted inhospital that reported binary RT-PCR tests, 24 (57\%) reported positive results for SARs-CoV-2 (142 positives out of 1,403 samples: average $10.1 \%$, range $0 \%$ to $100 \%$ ). There was no pattern between the type of hospital setting (ICU versus non-ICU) and RT-PCR positivity. Seventeen studies reported potential air transmission in the outdoors or in the community. Seven performed RT-PCR sampling, of which two studies report weak positive RNA samples for 2 or more genes (5 of 125 samples positive: average $4.0 \%$ ). Ten studies attempted viral culture

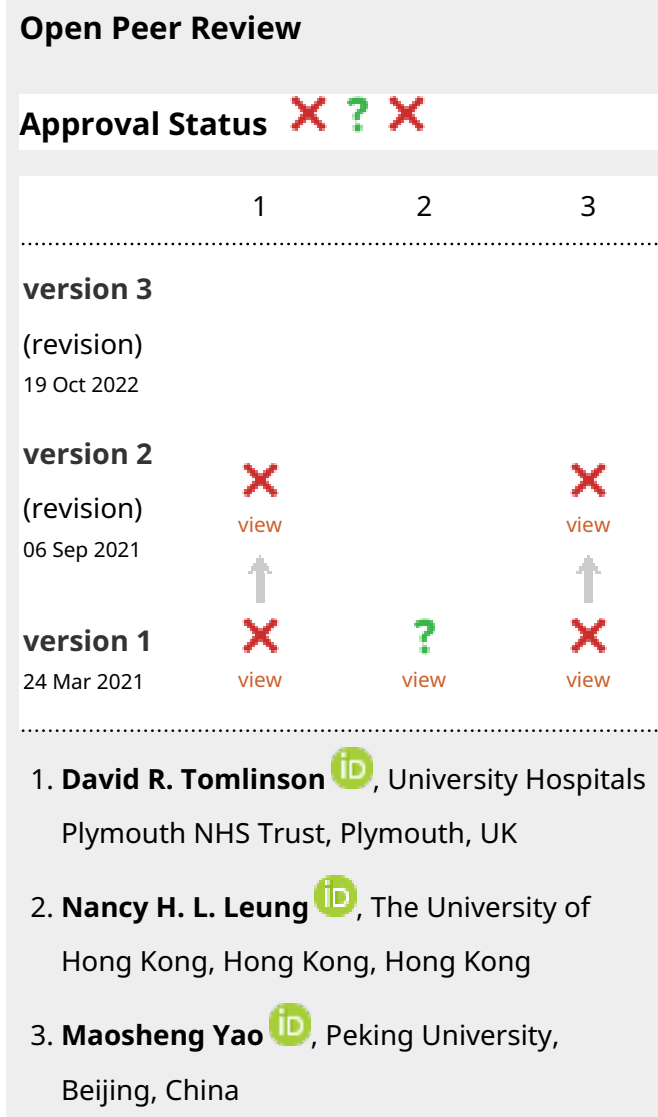

Any reports and responses or comments on the article can be found at the end of the article. 
with no serial passage for viral culture.

Conclusion: SARS-CoV-2 RNA is detected intermittently in the air in various settings. Standardized guidelines for conducting and reporting research on airborne transmission are needed. The lack of recoverable viral culture samples of SARS-CoV-2 prevents firm conclusions over airborne transmission.

Keywords

SARs-CoV-2, transmission, COVID, Airborne

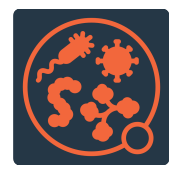

This article is included in the Pathogens

gateway.

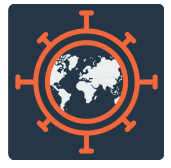

This article is included in the Emerging Diseases

and Outbreaks gateway.

This article is included in the Coronavirus

collection. 


\section{Corresponding author: Carl J. Heneghan (carl.heneghan@phc.ox.ac.uk)}

Author roles: Heneghan CJ: Formal Analysis, Funding Acquisition, Investigation, Methodology, Writing - Original Draft Preparation, Writing - Review \& Editing; Spencer EA: Data Curation, Formal Analysis, Investigation, Methodology, Project Administration, Writing Review \& Editing; Brassey J: Data Curation, Formal Analysis, Methodology, Writing - Review \& Editing; Plüddemann A: Data Curation, Formal Analysis, Writing - Review \& Editing; Onakpoya IJ: Data Curation, Formal Analysis, Methodology, Writing - Review \& Editing; Evans DH: Data Curation, Formal Analysis, Supervision, Writing - Review \& Editing; Conly JM: Formal Analysis, Investigation, Methodology, Supervision, Writing - Review \& Editing; Jefferson T: Conceptualization, Formal Analysis, Funding Acquisition, Investigation, Methodology, Project Administration, Writing - Original Draft Preparation, Writing - Review \& Editing

Competing interests: $\mathrm{CH}$ holds grant funding from the NIHR School of Primary Care Research, the NIHR BRC Oxford and the World Health Organization for a series of Living rapid review on the modes of transmission of SARs-CoV-2 reference WHO registration No2020/1077093. He has received expenses and fees for his media work. He receives expenses for teaching EBM and is also paid for his GP work in NHS out of hours (contract Oxford Health NHS Foundation Trust) and for appraising treatment recommendations in non-NHS settings. He is the Director of CEBM and is an NIHR Senior Investigator. TJ was in receipt of a Cochrane Methods Innovations Fund grant to develop guidance on the use of regulatory data in Cochrane reviews (2015-018). In 2014-2016, he was a member of three advisory boards for Boehringer Ingelheim. TJ was a member of an independent data monitoring committee for a Sanofi Pasteur clinical trial on an influenza vaccine. TJ is occasionally interviewed by market research companies about phase I or II pharmaceutical products for which he receives fees (current). TJ was a member of three advisory boards for Boehringer Ingelheim (2014-16). TJ was a member of an independent data monitoring committee for a Sanofi Pasteur clinical trial on an influenza vaccine (2015-2017). TJ is a relator in a False Claims Act lawsuit on behalf of the United States that involves sales of Tamiflu for pandemic stockpiling. If resolved in the United States' favour, he would be entitled to a percentage of the recovery. TJ is co-holder of a Laura and John Arnold Foundation grant for the development of a RIAT support centre (2017-2020) and Jean Monnet Network Grant, 2017-2020 for The Jean Monnet Health Law and Policy Network. TJ is an unpaid collaborator to the project Beyond Transparency in Pharmaceutical Research and Regulation led by Dalhousie University and funded by the Canadian Institutes of Health Research (2018-2022). TJ consulted for Illumina LLC on nextgeneration gene sequencing (2019-2020). TJ was the consultant scientific coordinator for the HTA Medical Technology programme of the Agenzia per i Serivizi Sanitari Nazionali (AGENAS) of the Italian MoH (2007-2019). TJ is Director of Medical Affairs for BC Solutions, a market access company for medical devices in Europe. TJ is funded by NIHR UK and the World Health Organization (WHO) to update Cochrane review A122, "Physical Interventions to interrupt the spread of respiratory viruses". TJ is funded by Oxford University to carry out a living review on the transmission epidemiology of COVID-19. Since 2020, TJ receives fees for articles published by The Spectator and other media outlets. TJ is part of a review group carrying out "Living rapid literature review on the modes of transmission of SARSCoV-2 (WHO Registration 2020/1077093-0)". He is a member of the WHO COVID-19 Infection Prevention and Control Research Working Group. DE has been awarded U.S. patents as a co-inventor of related oncolytic virus technologies and is a co-owner of Prophysis Inc., which retains a partial interest in the licensing rights for these technologies. JMC holds grants from the Canadian Institutes for Health Research on acute and primary care preparedness for COVID-19 in Alberta, Canada and was the primary local Investigator for a Staphylococcus aureus vaccine study funded by Pfizer for which all funding was provided only to the University of Calgary. He also received support from the Centers for Disease Control and Prevention (CDC) to attend an Infection Control Think Tank Meeting. AP holds grant funding from the NIHR School of Primary Care Research. IJO, EAS, and JB have no interests to disclose.

Grant information: The review was funded by the World Health Organization: Living rapid review on the modes of transmission of SARs-CoV-2 reference WHO registration No 2020/1077093. CH, AP and ES also receive funding support from the National Institute of Health Research School of Primary Care Research Evidence Synthesis Working Group project 390 (https://www.spcr.nihr.ac.uk/eswg). The funders had no role in study design, data collection and analysis, decision to publish, or preparation of the manuscript.

Copyright: (c) 2021 Heneghan CJ et al. This is an open access article distributed under the terms of the Creative Commons Attribution License, which permits unrestricted use, distribution, and reproduction in any medium, provided the original work is properly cited.

How to cite this article: Heneghan CJ, Spencer EA, Brassey J et al. SARS-CoV-2 and the role of airborne transmission: a systematic review [version 1; peer review: 1 approved with reservations, 2 not approved] F1000Research 2021, 10:232 https://doi.org/10.12688/f1000research.52091.1

First published: 24 Mar 2021, 10:232 https://doi.org/10.12688/f1000research.52091.1 


\section{Introduction}

Airborne transmission is defined as the spread of an infectious agent caused by the dissemination of droplet nuclei (aerosols) that remain infectious when suspended in air over long distances and time ${ }^{1}$. A collection of particles (liquid or solid) ranging in size from $0.001 \mu \mathrm{m}$ to over $100 \mathrm{~mm}$ suspended in a gas defines an aerosol ${ }^{2}$. Droplet nuclei are airborne residue (with or without embedded pathogens) of a respiratory droplet containing non-volatile solutes, from which water has evaporated to the point of equilibrium with the ambient relative humidity defines ${ }^{3}$.

Airborne transmission via droplets and aerosols enables some viruses to spread efficiently among humans, causing outbreaks that are difficult to control. Many studies, however, often report inconclusive findings as many outbreaks are studied retrospectively and evidence to inform transmission from controlled experiments is often not available ${ }^{4,5}$. Among case clusters for which airborne transmission is hypothesised, published detailed investigations cannot rule out that droplet and fomite transmission could also explain human-to-human transmission ${ }^{6}$. Therefore, we aimed to systematically review the airborne transmission evidence for SARS-CoV-2.

\section{Methods}

We are undertaking a series of living systematic reviews investigating factors and circumstances that impact the transmission of SARS-CoV-2, based on our published protocol last updated on 1 December 2020 (archived protocol: Extended data: Appendix $1^{7}$ ) Briefly, this review aims to identify, appraise, and summarize the evidence (from studies peer-reviewed or awaiting peer review) relating to the role of airborne transmission of SARS-CoV-2 and the factors influencing transmissibility.

We searched four main databases: LitCovid, medRxiv, Google Scholar and the WHO Covid-19 database for COVID-19 using the terms Airborne: aerosol OR airborne OR airbourne OR inhalation OR air OR droplet) from 1 February 2020 up to 20 December 2020 (see Extended data: Appendix 2 for the search strategies ${ }^{7}$ ). Searches were updated every two weeks. We aimed to include sampling for the detection of SARs-CoV-2 in the population or the environment on airborne transmission. Studies can be observational including case series, ecological, or prospective; or interventional including randomised trials and clinical reports, outbreak reports, case-control studies, experimental studies, non-predictive modelling. Studies should include sampling for the detection of SARs-CoV-2. Studies on factors influencing transmission are included, such as location settings, meteorological or immunological factors. Studies incorporating models to describe observed data were eligible. Studies reporting solely predictive modelling were excluded. For relevant articles citation tracking was undertaken. We searched the included studies of all retrieved reviews and included them in the results section for reference.

We included field studies that included airborne sampling for SARs-CoV-2 in the population or the environment. JB performed the searches, TJ and ES performed the first screen and $\mathrm{CH}$ checked these initial screening of studies. One reviewer (ES) extracted data for each study, and a second reviewer $(\mathrm{CH})$ checked and edited the extraction. We extracted information on the study characteristics, the study population, setting and methods, and the main results from included studies. We also extracted data on the type of study, setting, sample source and methods, RT-PCR positive samples for SARS-CoV-2 RNA including cycle threshold $(\mathrm{Ct})$ and copies per $\mathrm{m}^{3}$, viral culture methods and results, size of air particles (when reported) and proportion in the sample. We tabulated the data and summarised the data narratively by type of sample. Because of substantial heterogeneity across the included studies, we did not perform a meta-analysis. We assessed quality using a modified QUADAS 2 risk of bias tool, ${ }^{8}$. We simplified the tool as the included studies were not designed as primary diagnostic accuracy studies and the quality of transmission studies is known to be low . We gave particular importance to the description of methods for air sampling and the reporting of sufficient detail to replicate. We summarise data narratively and report the outcomes as stated in the paper, including quantitative estimates when reported and the detection of culture of SARS-CoV-2.

\section{Results}

We identified 89 studies (see Figure 1; 19 full-text studies were excluded because they were not reviews or there was no SARs-CoV-2 airborne transmission outcome studied and we excluded four laboratory studies: see Extended data: Appendix 3 for a list of excluded studies ${ }^{7}$ ). We included 67 primary studies and 22 systematic reviews (see Extended data: Appendix 3 for references to included studies and Table 1 and Table 2 for the characteristics of the included studies ${ }^{7}$ ).

\section{Reviews}

We found 22 reviews on SARS-CoV-2: 16 reviews [Anderson EL 2020, Agarwal 2020, Bahl P 2020, Birgand G 2020, Carducci A 2020, Chen PZ 2020, Comber L 2020, Ekram W 2020, Ji B 2020, Mehraeen E 2020, Niazi S 2020, Noorimotlagh Z 2020, Rahmani 2020, Ren Y 2020, Singhal S 2020, and Wilson NM 2020] were about airborne transmission and prevention; three reviews on airborne transmission and procedures [Hussain A 2020, Kay JK 2020, and Schünemann HJ] and three on ventilation, air conditioning filtration and recirculation [Mousavi EH 2020, Chirico F 2020, and Correia G 2020] (see Table 2). The final search date of these reviews varied from April up to 27 October 2020. Only five reviews met systematic review methods criteria that include systematically searching for all available evidence, appraising the quality of the included studies, and synthesising the evidence into a usable form ${ }^{10}$.

\section{Quality of included primary studies ( $n=67)$}

All included primary studies were observational (some with experimental components) and low quality (see Table 3). We could not identify a published protocol for any of the studies. Most studies were based on convenience sampling. While the description of methods provided sufficient detail to replicate $91 \%$ of studies (see Figure 2), the research often lacked standard methods, standard sampling sizes and reporting. In $69 \%$ of the 


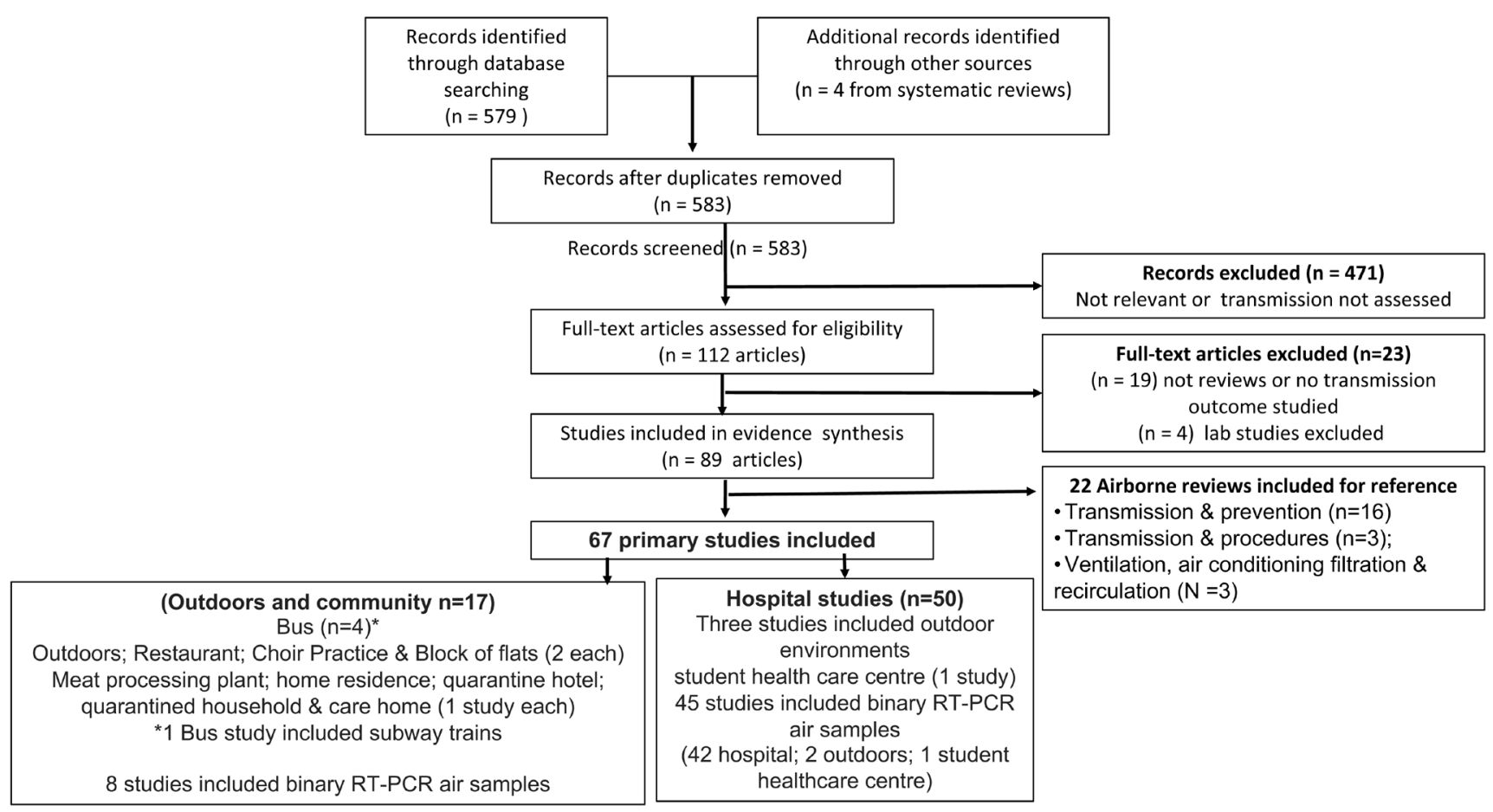

Figure 1. Flow chart.

studies, the sample sources were clear, however, outcomes that aimed to demonstrate the detection of viable, replicable viruses were lacking. Limitations of the sampling methods and the poor-quality reporting make it difficult to discriminate between airborne or droplet nuclei transmission. Interpretation is further limited by the variability in reporting of patient distance from the sampler, use of protective or oxygen masks by patients, patient activities (coughing and sneezing during sampling time), air movement, air conditioning sampler type, sampling, storage and transfer conditions.

\section{Primary studies}

We included 67 primary studies, of which 53 (79\%) reported binary data on RT-PCR air samples (see Table 1). All were descriptive observational and none were comparative. Twelve studies reported $\mathrm{Ct}$ values and 18 report copies per sample volume (see Table 4). Two studies reported a $\mathrm{Ct}$ value $<25$ : Razzini $\mathrm{K}$ 2020 et al. reports in the intensive care unit the mean $\mathrm{Ct}$ was 22.6, and Guo ZD 2020 et al. report a Ct of 12.5 near the doctor's office area. Ten studies report Ct values > 35; two [Guo ZD 2020, Lei $\mathrm{H}$ 2020] report $\mathrm{Ct}>40$, and three studies [DumontLeblond 2020, Kenarkoohi 2020, Nissen 2020] report the detection of single genes.

Table 5 shows eight studies reporting the size of detectable particles containing RNA [Binder 2020, Chia PY 2020, Chirizzi D 2020, Feng B 2020, Hernández JL 2020, Liu Y \& Ning Z 2020, McGain F 2020, and Santarpia 2020a]. Overall the reporting was heterogeneous. SARS-CoV-2 RNA was detectable in a range of air sample sizes from $<1 \mu \mathrm{m}$ through to $>18 \mu \mathrm{m}$.
Seven studies detected particles below $<4 \mu \mathrm{m}$, and Chirizzi D 2020 et al. reported on coarse particles up to diameter $>18 \mu \mathrm{m}$. In one study, different samplers detected different size particles: McGain F 2020 et al. reported that the APS detected larger aerosols (> $0.37 \mu \mathrm{m})$ and MiniWRAS smaller particles (0.01-0.35 $\mu \mathrm{m})$ (see Figure 3).

We found 36 different descriptions of air samplers deployed: the two most used samplers were the MD8 sampler, Sartorius, Goettingen, Germany ( $\mathrm{n}=7$ studies) and the National Institute for Occupational Safety and Health (NIOSH) BC 251 Aerosol sampler ( $\mathrm{n}=6$ studies) (see Extended data: Appendix $4^{7}$ ). One study used four different methods [Ding Z 2020], and in seven studies the sampler used was unclear [Hernández JL 2020, Horve PF 2020, Kang M 2020, Kwon KS 2020, Seyyed Mahdi SM 2020, Tan L 2020 and Zhang D 2020].

Hospital. There were 50 studies conducted in healthcare settings: 45 studies included binary RT-PCR air samples (42 hospitals, 2 outdoors and 1 student healthcare centre).

Of the 42 studies that reported air sampling RT-PCR data within a hospital environment, $24(57 \%)$ reported positive samples (142 positives out of 1,403 samples: average $10.1 \%$ ). Samples taken per study varied from 2 to 135. In two studies [Ahn 2020 and Santarpia JL 2020b] the denominator was unclear. There was no pattern observed in terms of the type of hospital setting (ICU versus non-ICU) and RT-PCR positivity. Three studies involving ICUs reported $0 \%$ of samples were positive $[\mathrm{Ma} \mathrm{J}$, Song Z, Wu S] (see Figure 4). 


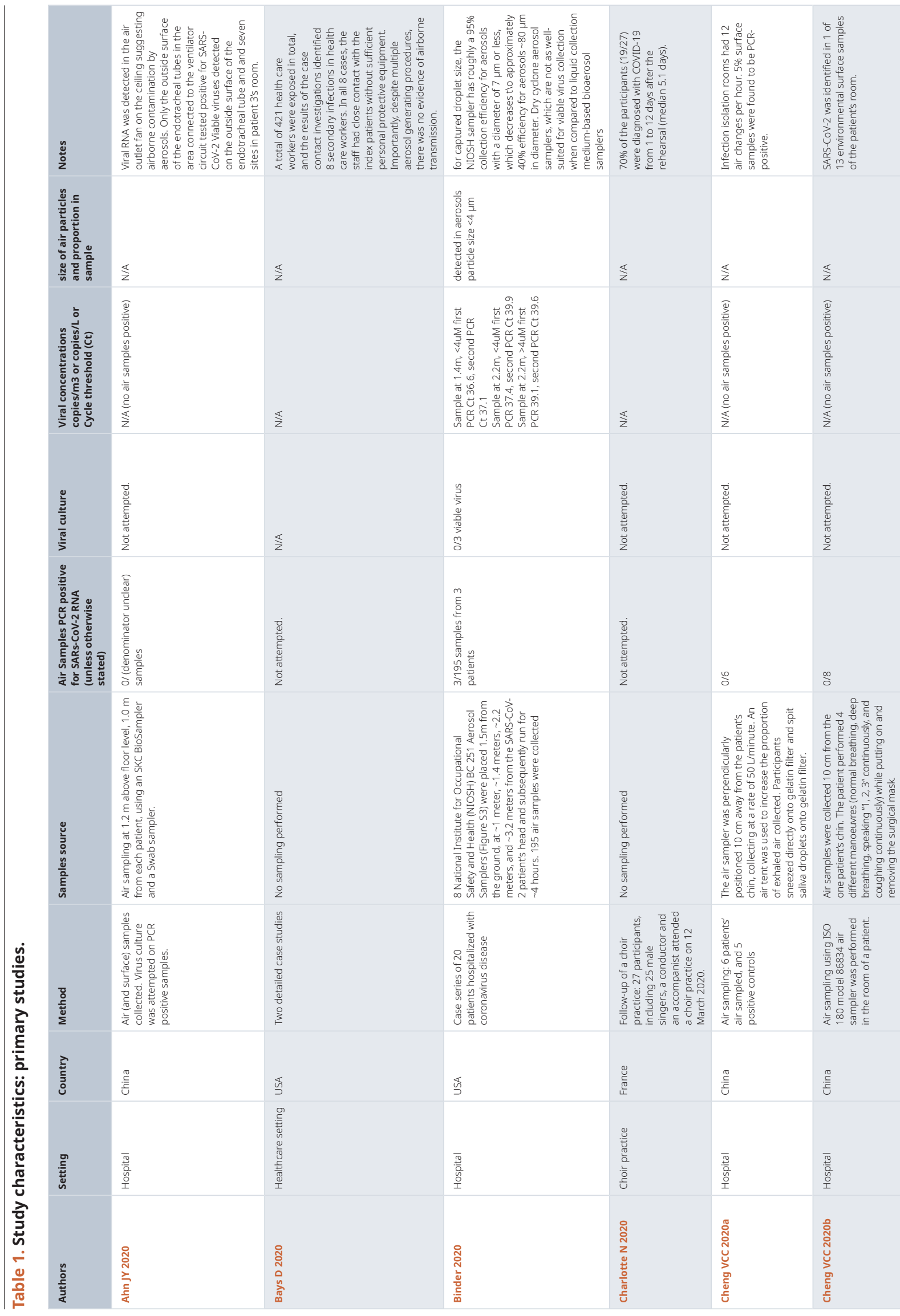




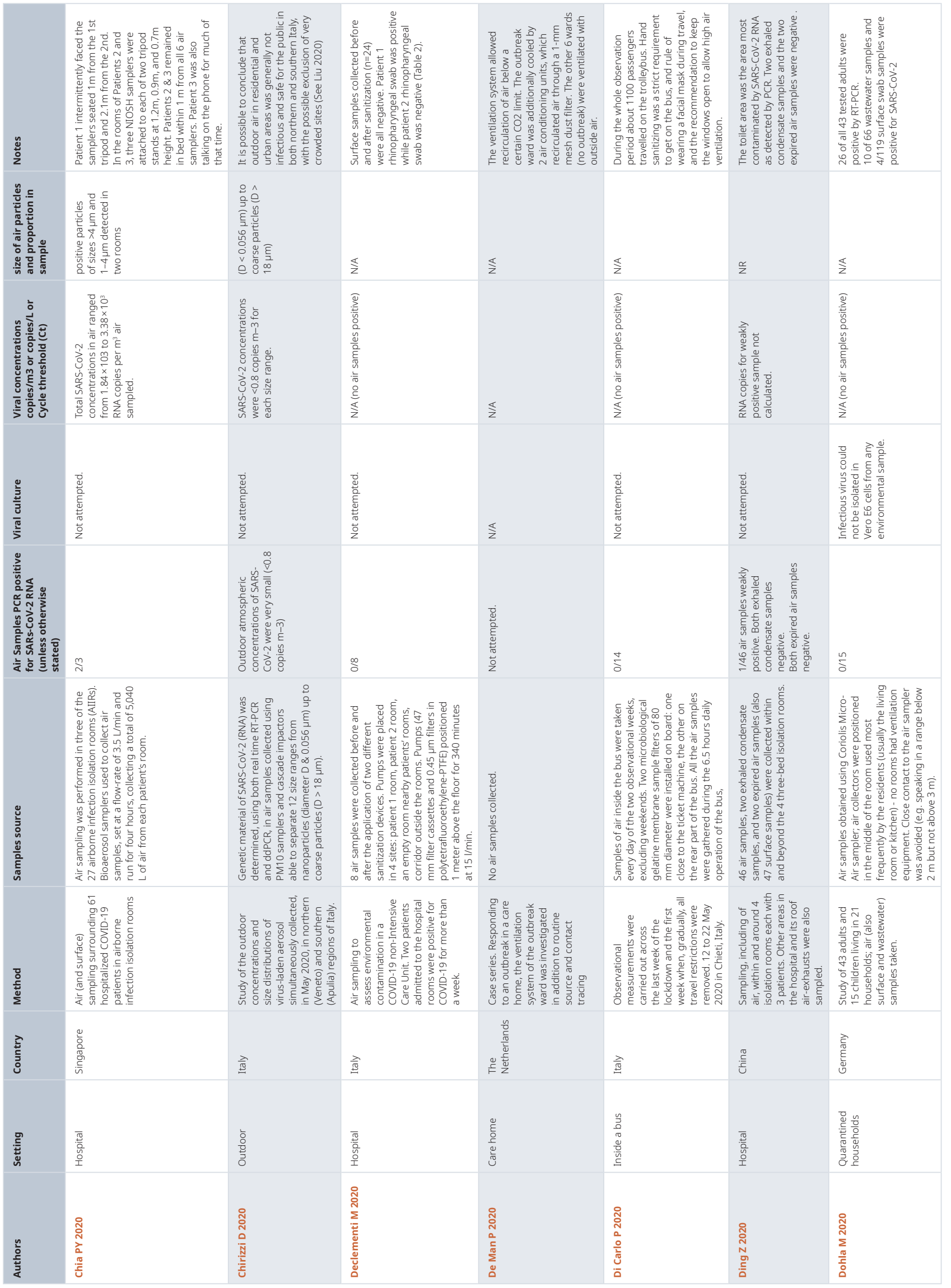




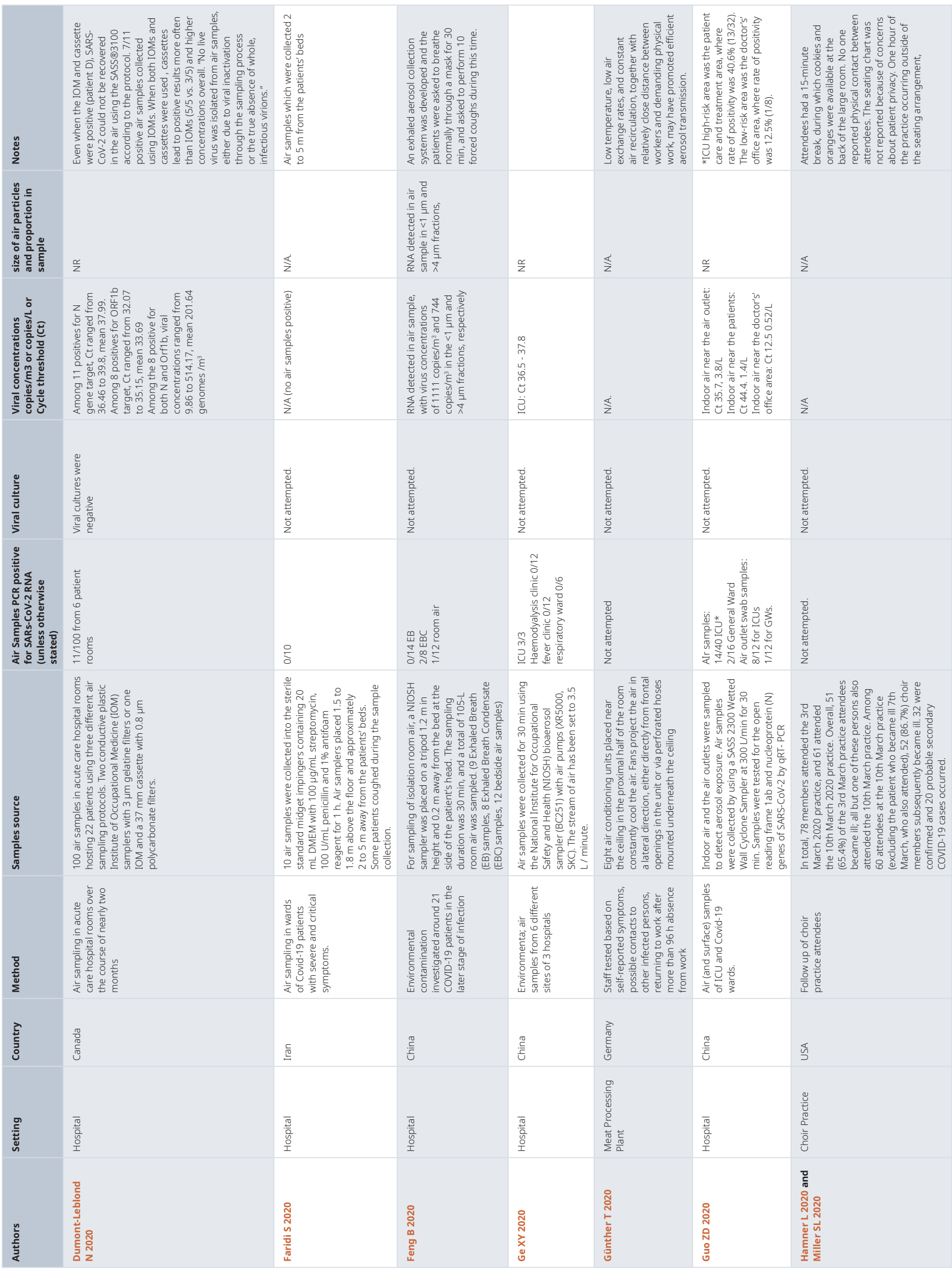




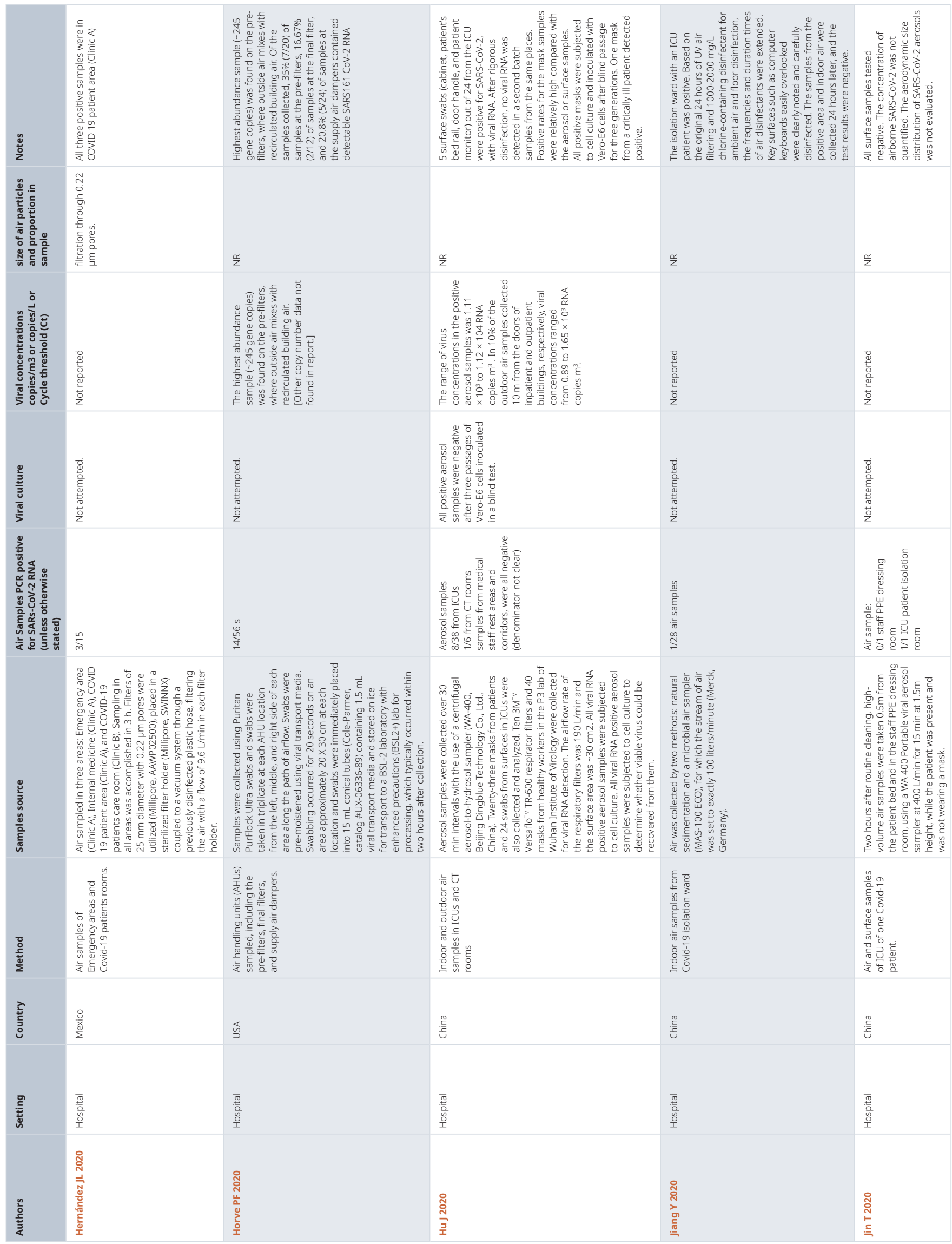

Page 9 of 74 


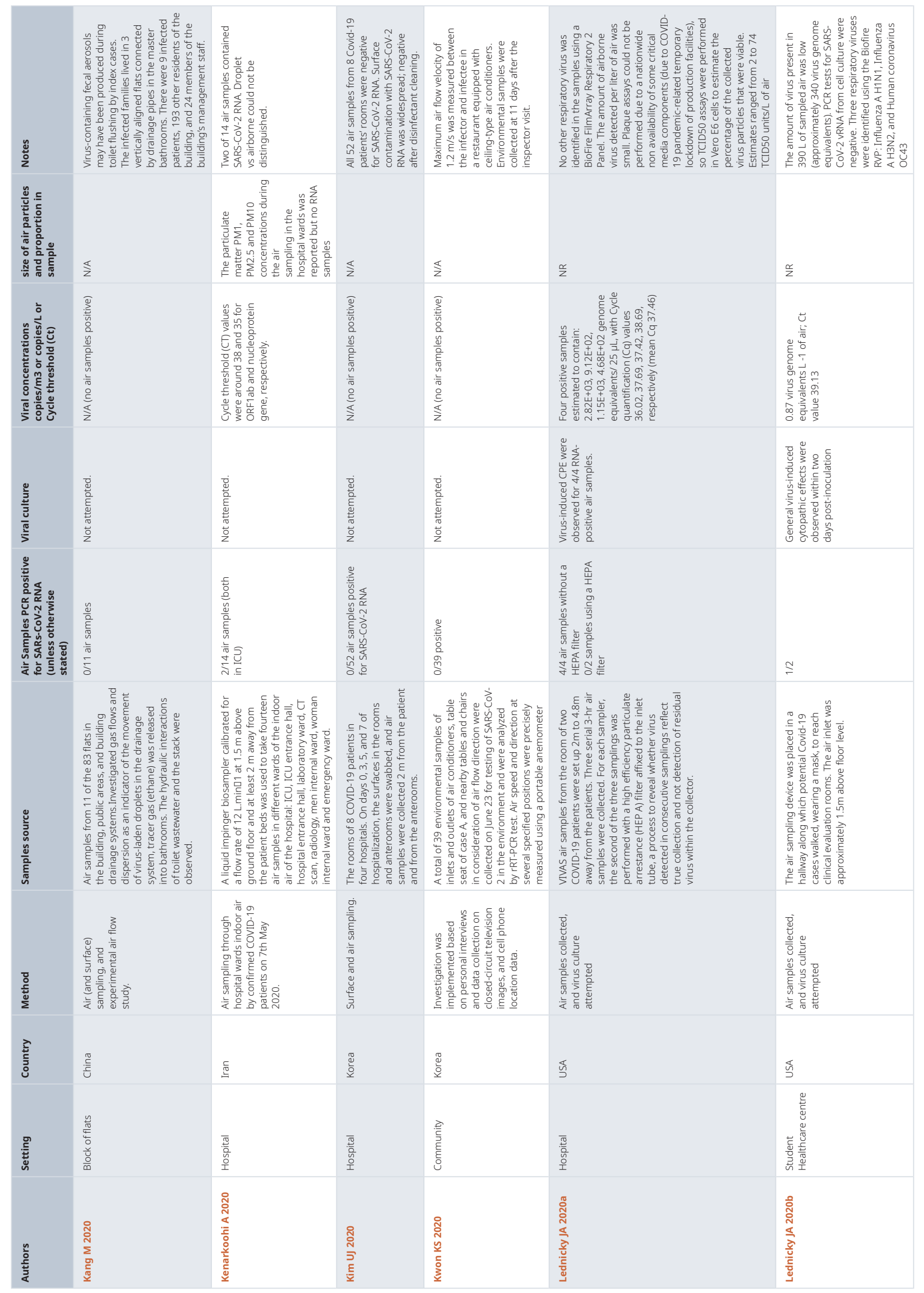




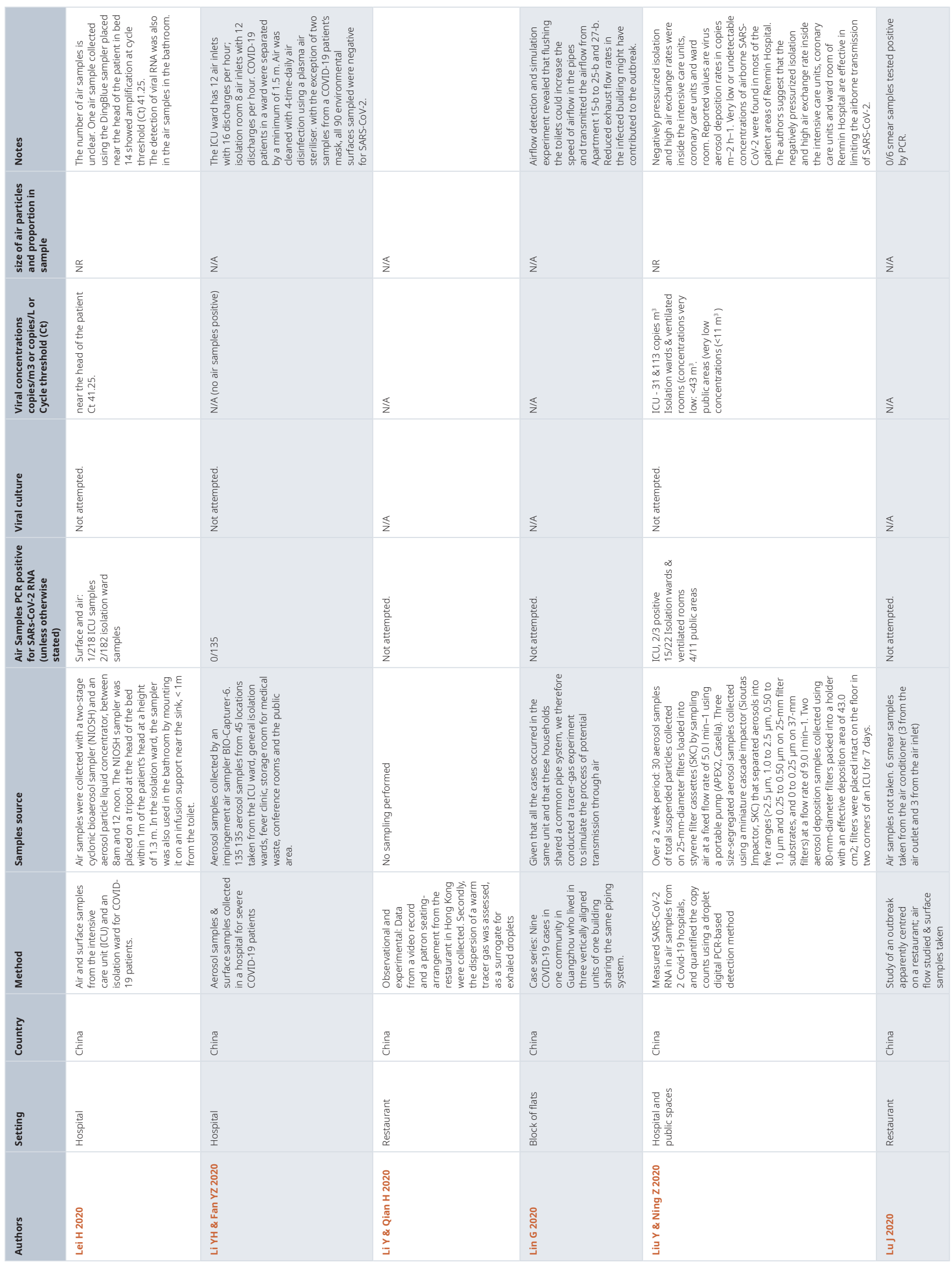




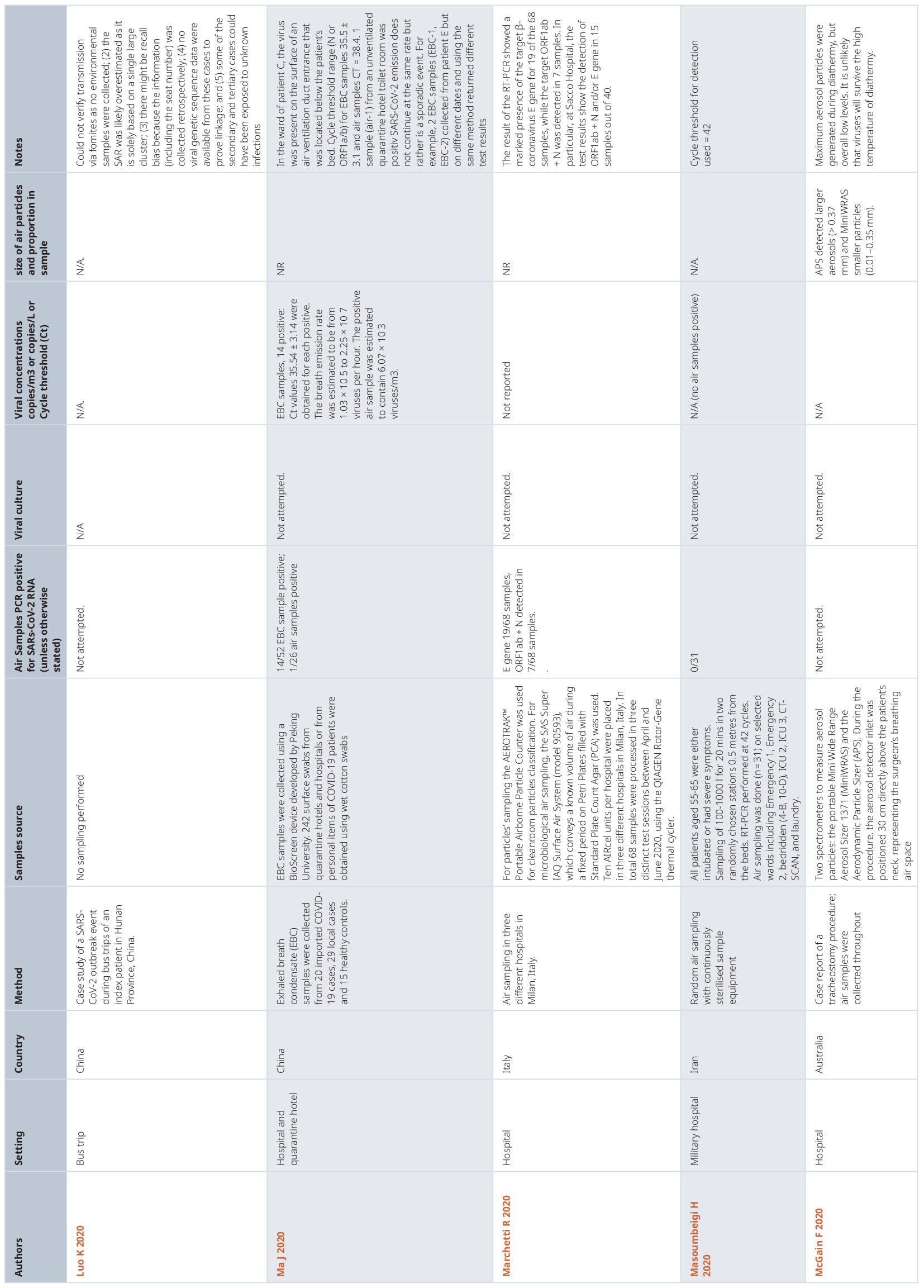




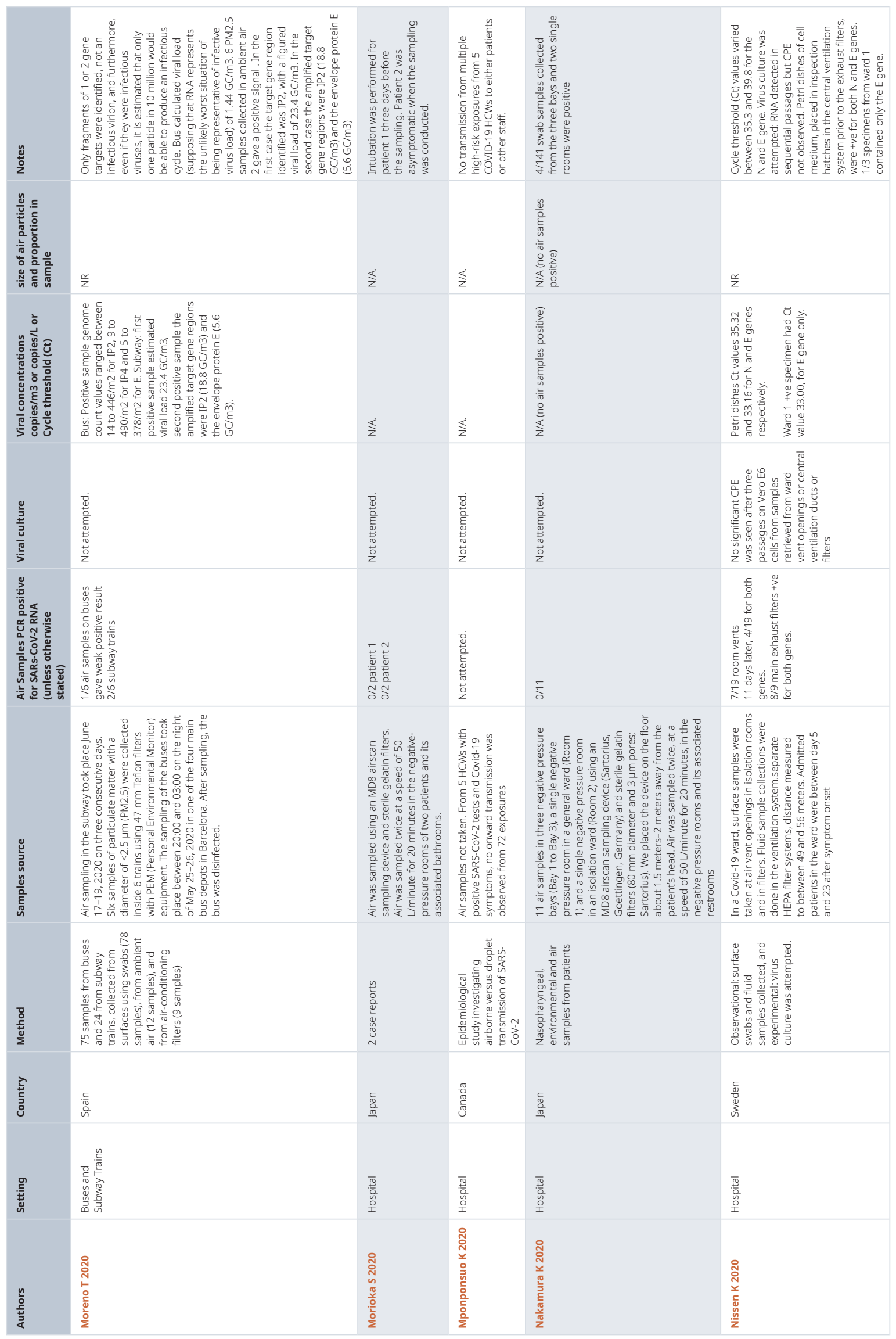




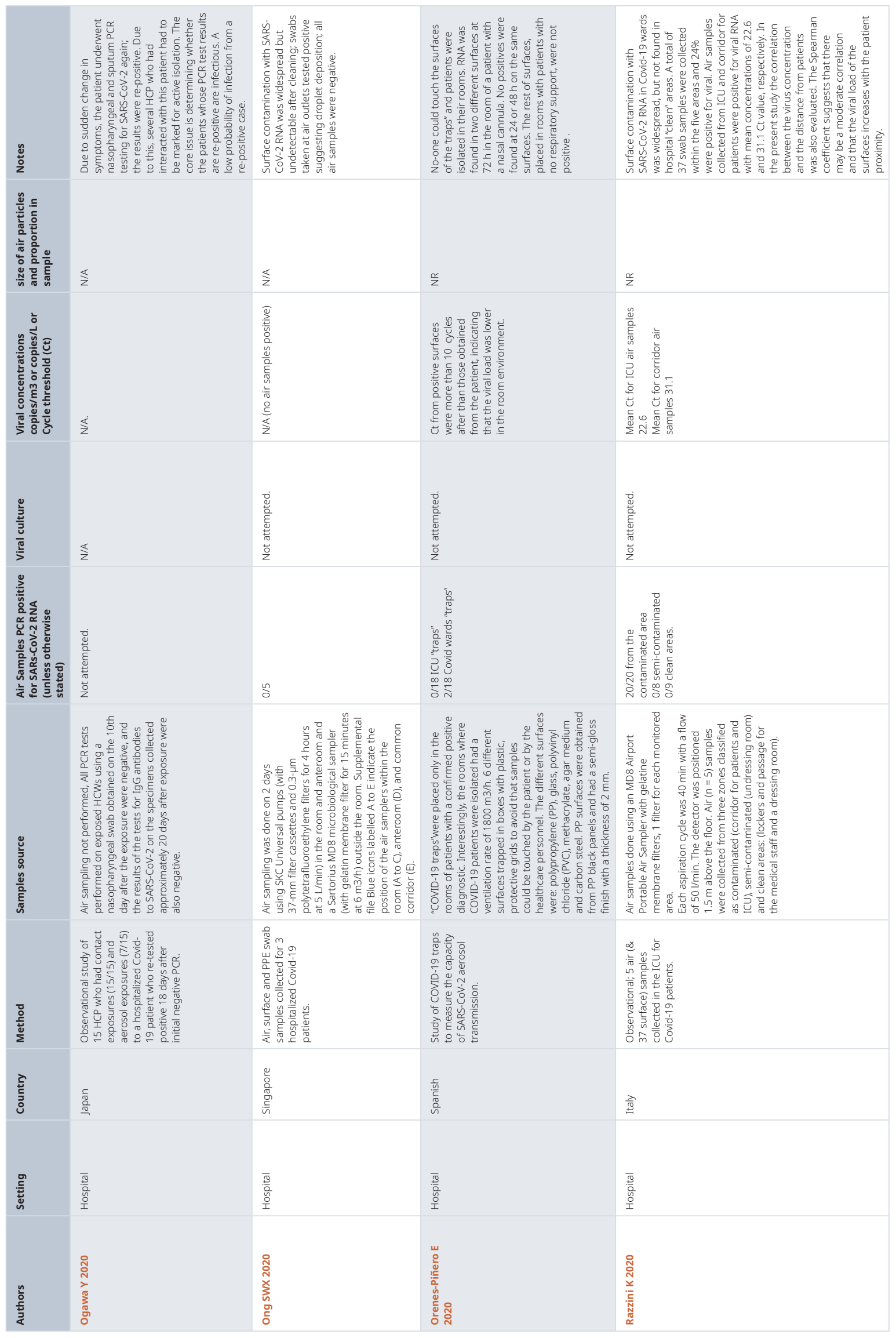




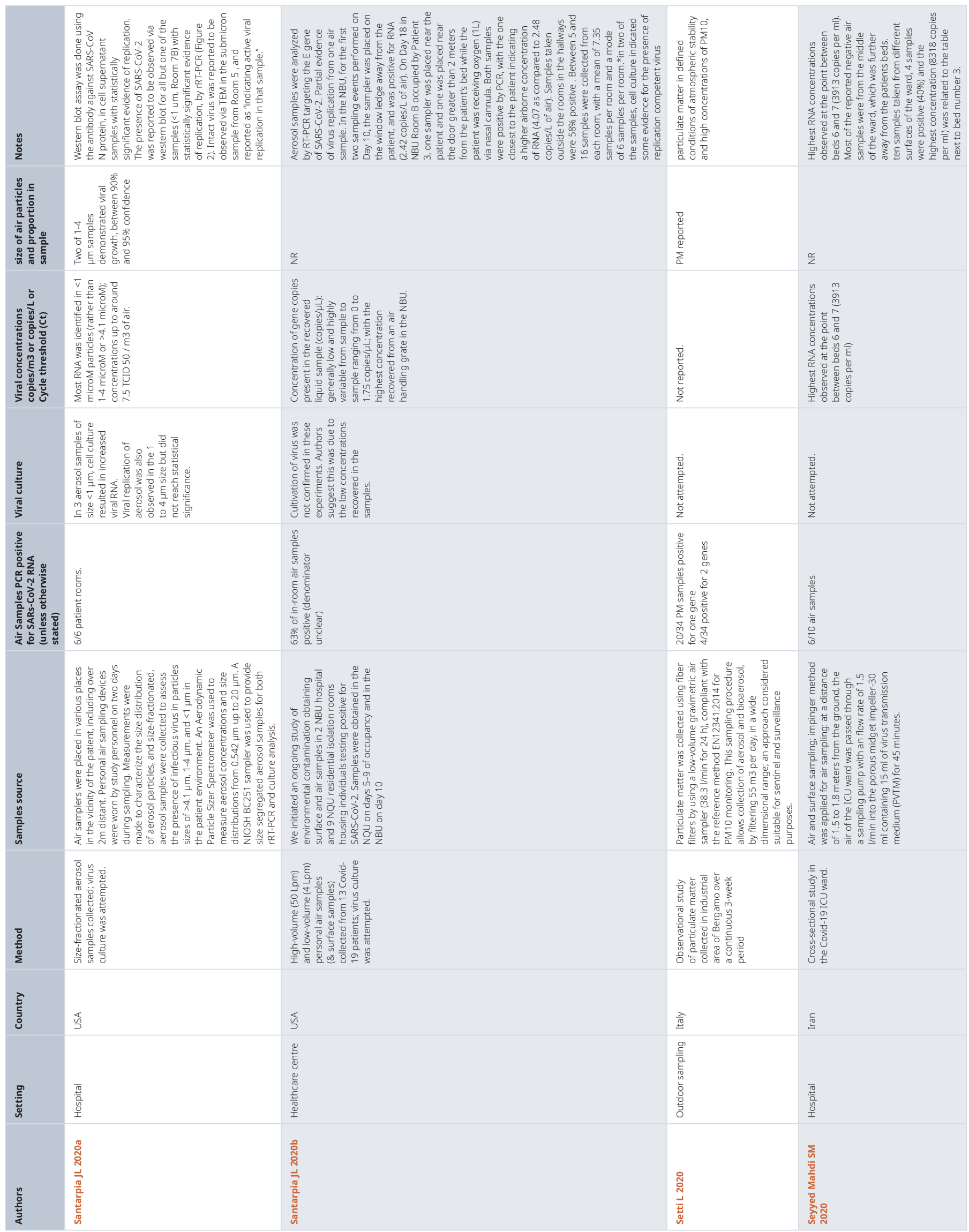




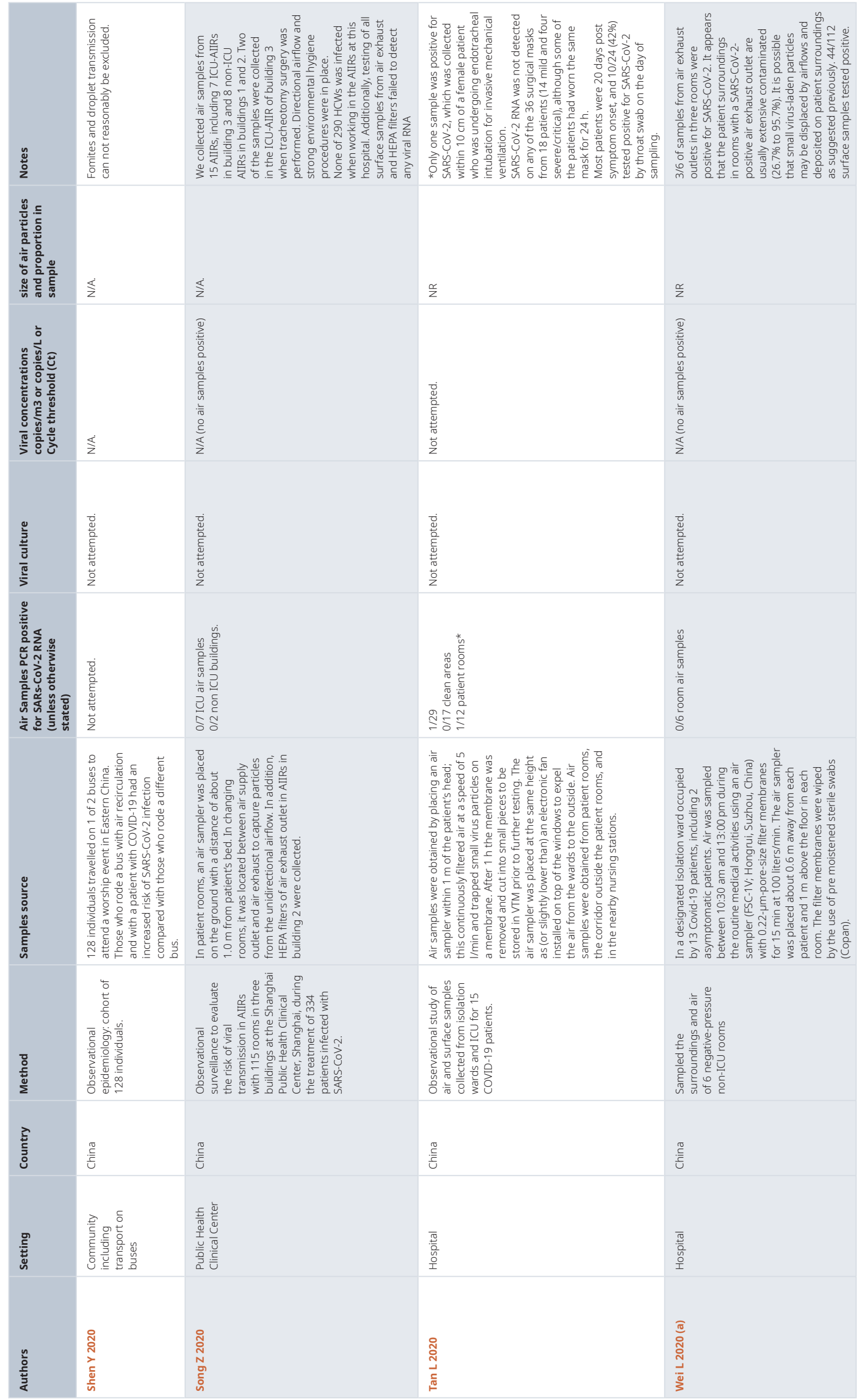




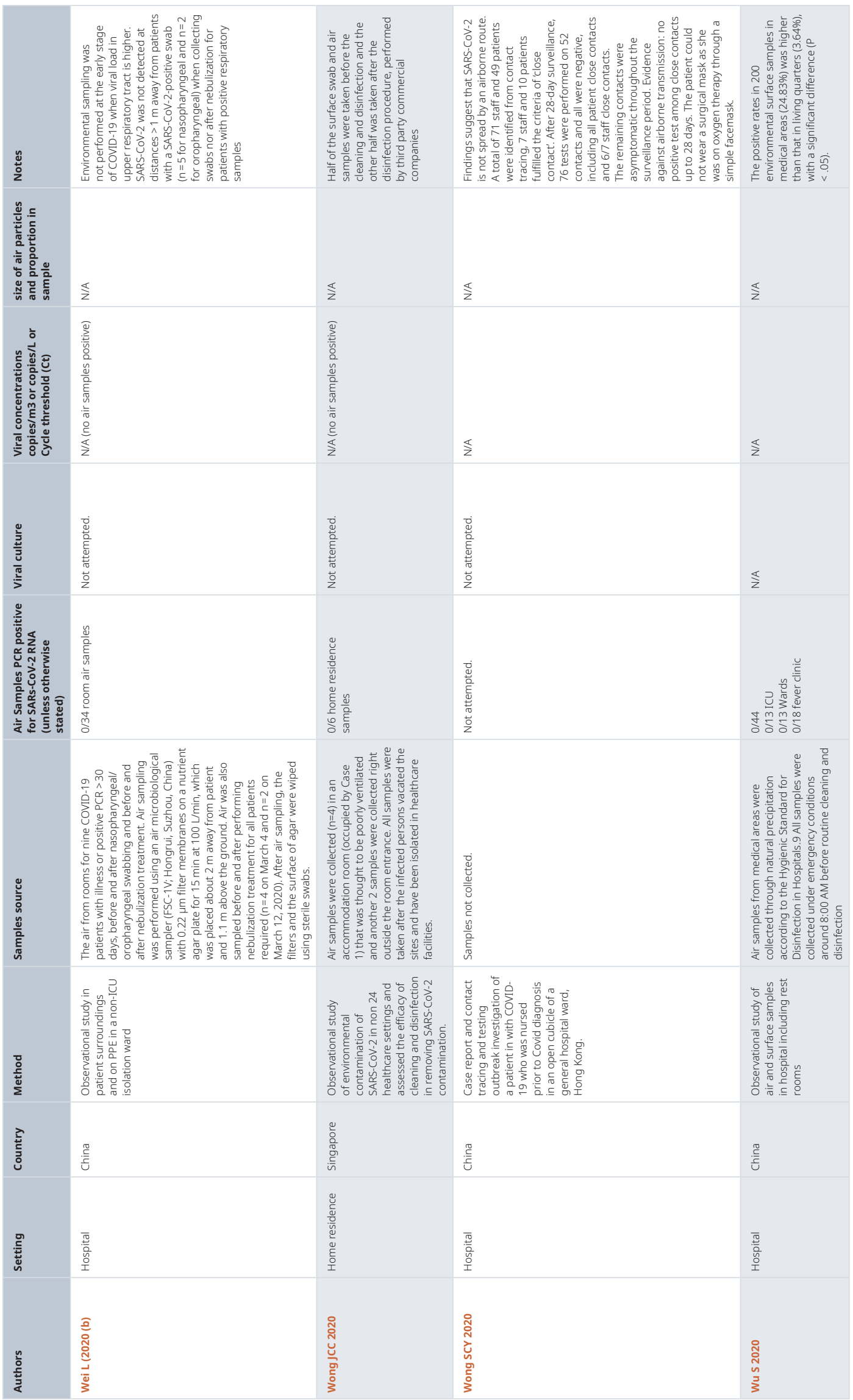




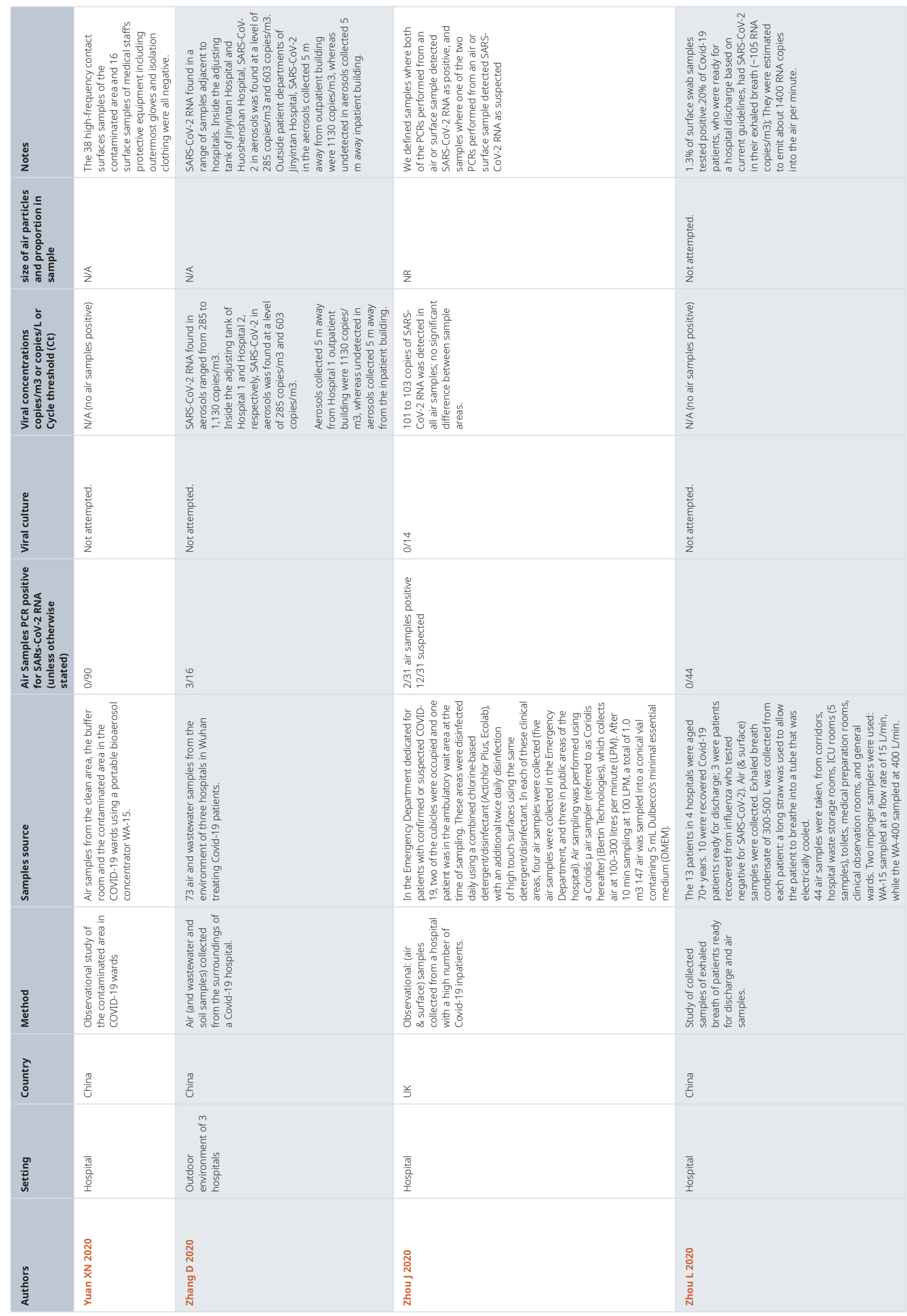




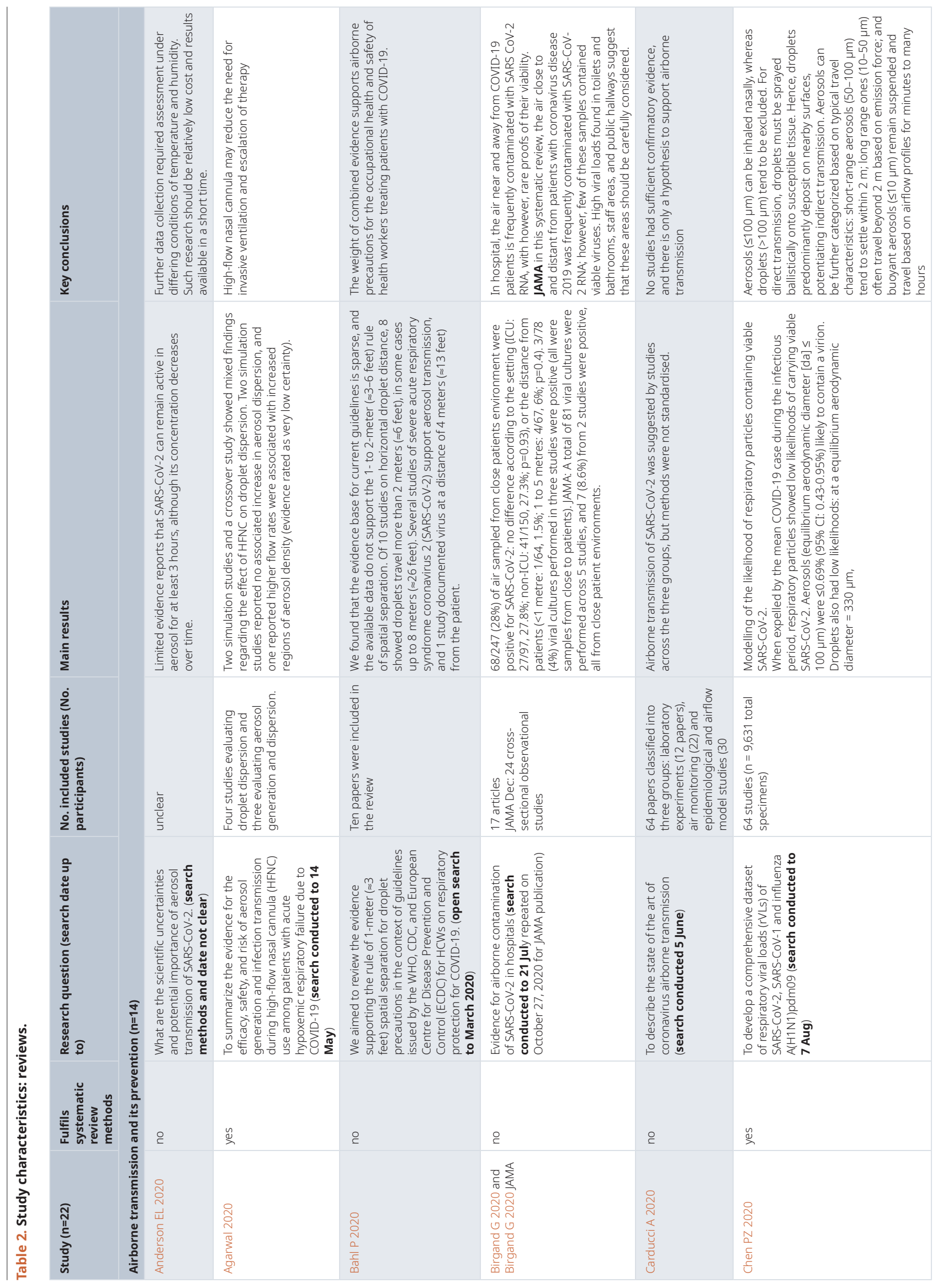




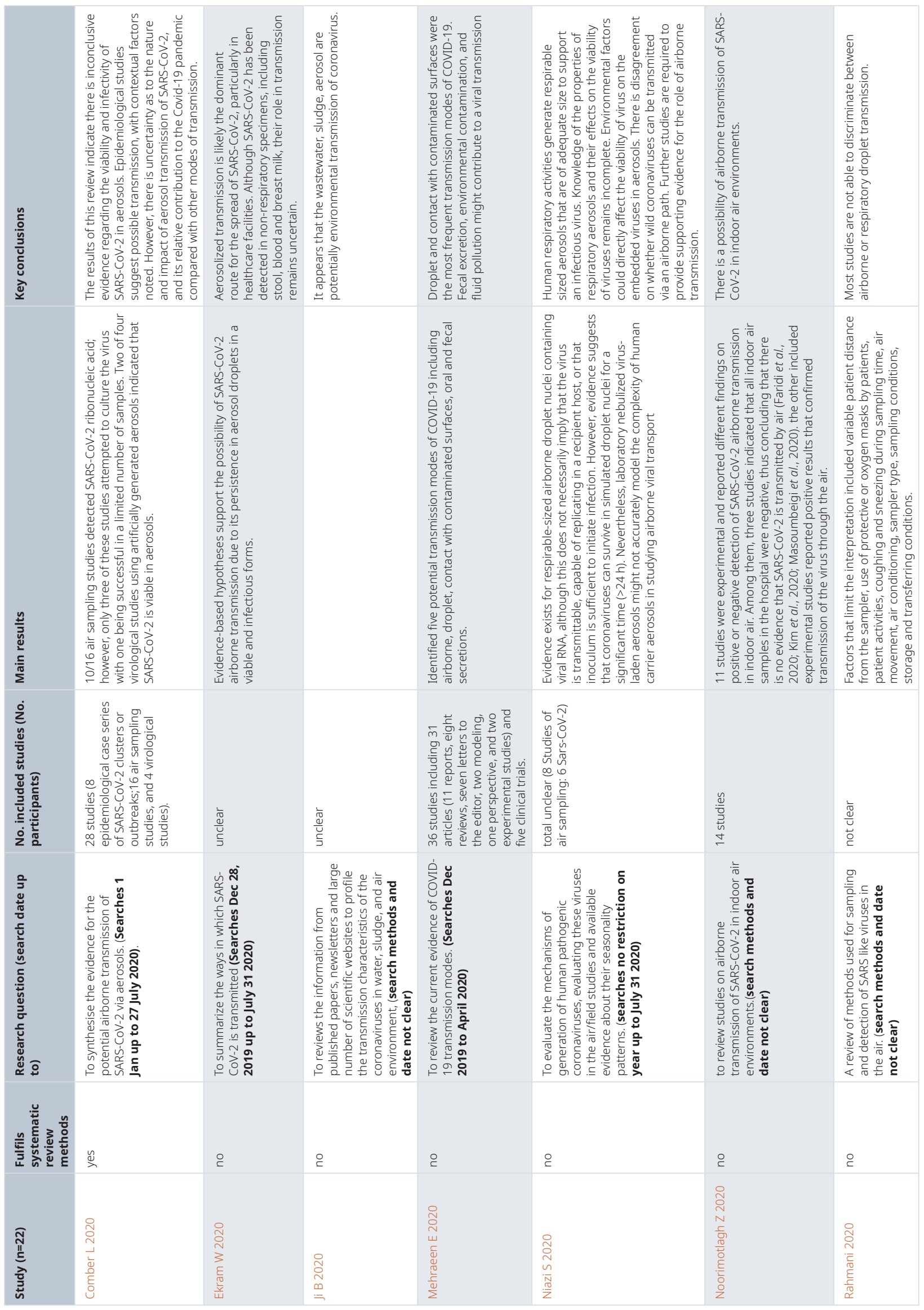




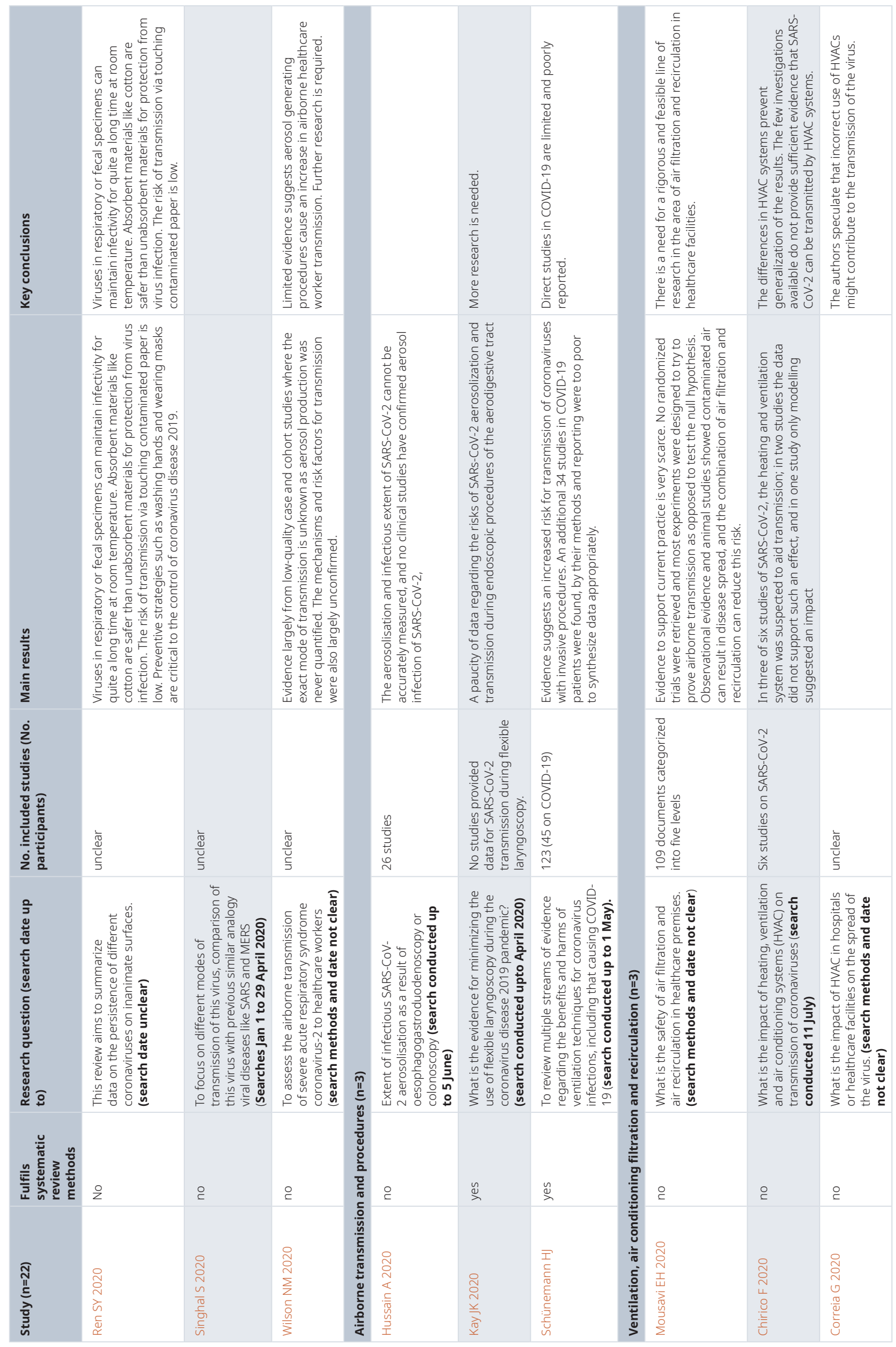


Table 3. Quality of included studies.

\begin{tabular}{|c|c|c|c|c|c|}
\hline Study & $\begin{array}{l}\text { Is the source } \\
\text { popn adequately } \\
\text { described }\end{array}$ & $\begin{array}{l}\text { Description of } \\
\text { methods and } \\
\text { sufficient detail } \\
\text { to replicate }\end{array}$ & $\begin{array}{l}\text { Samples sources } \\
\text { clear and } \\
\text { quantified }\end{array}$ & $\begin{array}{l}\text { Analysis \& } \\
\text { reporting } \\
\text { outcomes } \\
\text { appropriate }\end{array}$ & $\begin{array}{l}\text { Was follow up } \\
\text { sufficient }\end{array}$ \\
\hline Ahn JY 2020 & Yes & Yes & No & Unclear & Not Applicable \\
\hline Bays D 2020 & Yes & Yes & Not Applicable & Yes & Yes \\
\hline Binder 2020 & Yes & Yes & Yes & Yes & Yes \\
\hline Charlotte N 2020 & Yes & Unclear & Not Applicable & Unclear & Yes \\
\hline Cheng VCC 2020a & Yes & Yes & Yes & Yes & Not Applicable \\
\hline Cheng VCC 2020b & Unclear & Yes & Yes & Unclear & Not Applicable \\
\hline Chia PY 2020 & Yes & Yes & Yes & Yes & Not Applicable \\
\hline Chirizzi D 2020 & Not Applicable & Yes & Yes & Yes & Not Applicable \\
\hline Declementi M 2020 & Yes & Yes & Yes & Yes & Not Applicable \\
\hline De Man P 2020 & Unclear & Yes & Not Applicable & Unclear & Not Applicable \\
\hline Di Carlo P 2020 & Not Applicable & Yes & Yes & Yes & Not Applicable \\
\hline Ding Z 2020 & Yes & Yes & Yes & Unclear & Not Applicable \\
\hline Döhla M 2020 & Unclear & Yes & Yes & Unclear & Not Applicable \\
\hline $\begin{array}{l}\text { Dumont-Leblond } \\
2020\end{array}$ & Yes & Yes & Yes & Yes & Not Applicable \\
\hline Faridi S 2020 & Yes & Yes & Yes & Yes & Not Applicable \\
\hline Feng B 2021 & Yes & Yes & Yes & Yes & Not Applicable \\
\hline Ge XY 2020 & Yes & Unclear & Yes & Unclear & Not Applicable \\
\hline Günther T 2020 & Yes & Yes & Yes & Unclear & Yes \\
\hline Guo ZD 2020 & Yes & Yes & Yes & Yes & Not Applicable \\
\hline $\begin{array}{l}\text { Hamner } 2020 \text { and } \\
\text { Miller SL } 2020\end{array}$ & Yes & Yes & Not Applicable & Unclear & Yes \\
\hline Hernández JL 2020 & Unclear & Yes & Yes & Yes & Not Applicable \\
\hline Horve PF 2020 & Yes & Yes & Yes & Yes & Not Applicable \\
\hline HuJ 2020 & Yes & Yes & Yes & Unclear & Not Applicable \\
\hline Jiang Y 2020 & Yes & Yes & Unclear & Unclear & Not Applicable \\
\hline Jin T 2020 & Yes & Yes & Yes & Yes & Not Applicable \\
\hline Kang M 2020 & Yes & Yes & Unclear & Unclear & Not Applicable \\
\hline Kenarkoohi A 2020 & Yes & Yes & Yes & Unclear & Not Applicable \\
\hline Kim UJ 2020 & Yes & Yes & Yes & Yes & Not Applicable \\
\hline Kwon KS 2020 & Yes & Yes & Not Applicable & Yes & Yes \\
\hline Lednicky JA 2020a & Yes & Yes & Yes & Unclear & Not Applicable \\
\hline Lednicky JA 2020b & Yes & Yes & Yes & Unclear & Not Applicable \\
\hline Lei H 2020 & Yes & Yes & Yes & Yes & Not Applicable \\
\hline Li Y \& Qian H 2020 & Yes & Yes & Not Applicable & Yes & Yes \\
\hline Li YH \& Fan YZ 2020 & Yes & Yes & Yes & Yes & Not Applicable \\
\hline Lin G 2020 & Yes & Yes & Not Applicable & Yes & Not Applicable \\
\hline Liu Y, Ning Z 2020 & Yes & Yes & Yes & Yes & Not Applicable \\
\hline
\end{tabular}




\begin{tabular}{|c|c|c|c|c|c|}
\hline Study & $\begin{array}{l}\text { Is the source } \\
\text { popn adequately } \\
\text { described }\end{array}$ & $\begin{array}{l}\text { Description of } \\
\text { methods and } \\
\text { sufficient detail } \\
\text { to replicate }\end{array}$ & $\begin{array}{l}\text { Samples sources } \\
\text { clear and } \\
\text { quantified }\end{array}$ & $\begin{array}{l}\text { Analysis \& } \\
\text { reporting } \\
\text { outcomes } \\
\text { appropriate }\end{array}$ & $\begin{array}{l}\text { Was follow up } \\
\text { sufficient }\end{array}$ \\
\hline Lu J 2020 & Yes & Unclear & Not Applicable & Unclear & Not Applicable \\
\hline Luo K 2020 & Yes & Yes & Not Applicable & Yes & Yes \\
\hline Ma J 2020 & Yes & Yes & Yes & Yes & Not Applicable \\
\hline Marchetti 2020 & Yes & Yes & Unclear & Unclear & Not Applicable \\
\hline Masoumbeigi 2020 & Yes & Yes & Yes & Yes & Not Applicable \\
\hline McGain F & Yes & Yes & Unclear & Unclear & Not Applicable \\
\hline Moreno 2020 & Not Applicable & Yes & Yes & Yes & Not Applicable \\
\hline Morioka S 2020 & Yes & Yes & Not Applicable & Unclear & Not Applicable \\
\hline $\begin{array}{l}\text { Mponponsuo K } \\
2020\end{array}$ & Yes & Yes & Not Applicable & Yes & Yes \\
\hline Nakamura K 2020 & Yes & Yes & Yes & Yes & Not Applicable \\
\hline Nissen K 2020 & Yes & Unclear & Yes & Unclear & Not Applicable \\
\hline Ogawa Y 2020 & Yes & Yes & Yes & Yes & Yes \\
\hline Ong SwX 2020 & Yes & Yes & Yes & Yes & Not Applicable \\
\hline $\begin{array}{l}\text { Orenes-Piñero E } \\
2020\end{array}$ & Yes & Yes & Not Applicable & Yes & Not Applicable \\
\hline Razzini K 2020 & Yes & Yes & Yes & Yes & Not Applicable \\
\hline Santarpia JL 2020a & Yes & Yes & Yes & Unclear & Not Applicable \\
\hline Santarpia JL 2020b & Yes & Yes & Yes & No & Not Applicable \\
\hline Setti L 2020 & Not Applicable & Yes & Yes & Yes & Not Applicable \\
\hline $\begin{array}{l}\text { Seyyed Mahdi SM } \\
2020\end{array}$ & Yes & Yes & Yes & Unclear & Not Applicable \\
\hline Shen Y 2020 & Unclear & Yes & Not Applicable & No & Unclear \\
\hline Song Z 2020 & Unclear & Yes & Yes & Yes & Not Applicable \\
\hline Tan L 2020 & Yes & Yes & Yes & Unclear & Not Applicable \\
\hline Wei L 2020a & Yes & Yes & Yes & Yes & Not Applicable \\
\hline Wei L 2020b & Yes & Yes & Yes & Yes & Not Applicable \\
\hline Wong JCC 2020 & Yes & Yes & Unclear & Yes & Not Applicable \\
\hline Wong SCY 2020 & Yes & Yes & Not Applicable & Yes & Yes \\
\hline Wu S 2020 & Yes & Unclear & Yes & Unclear & Not Applicable \\
\hline Yuan XN 2020 & Unclear & Unclear & Unclear & Unclear & Not Applicable \\
\hline Zhang D 2020 & Yes & Unclear & Yes & Unclear & Not Applicable \\
\hline Zhou J 2020 & Yes & Yes & Yes & Yes & Not Applicable \\
\hline Zhou L 2020 & Yes & Yes & Yes & Yes & Not Applicable \\
\hline \multirow[t]{3}{*}{ Total } & 56 & 60 & 46 & 39 & 11 \\
\hline & 67 & 67 & 67 & 67 & 67 \\
\hline & $83.6 \%$ & $89.6 \%$ & $68.7 \%$ & $58.2 \%$ & $16.4 \%$ \\
\hline
\end{tabular}




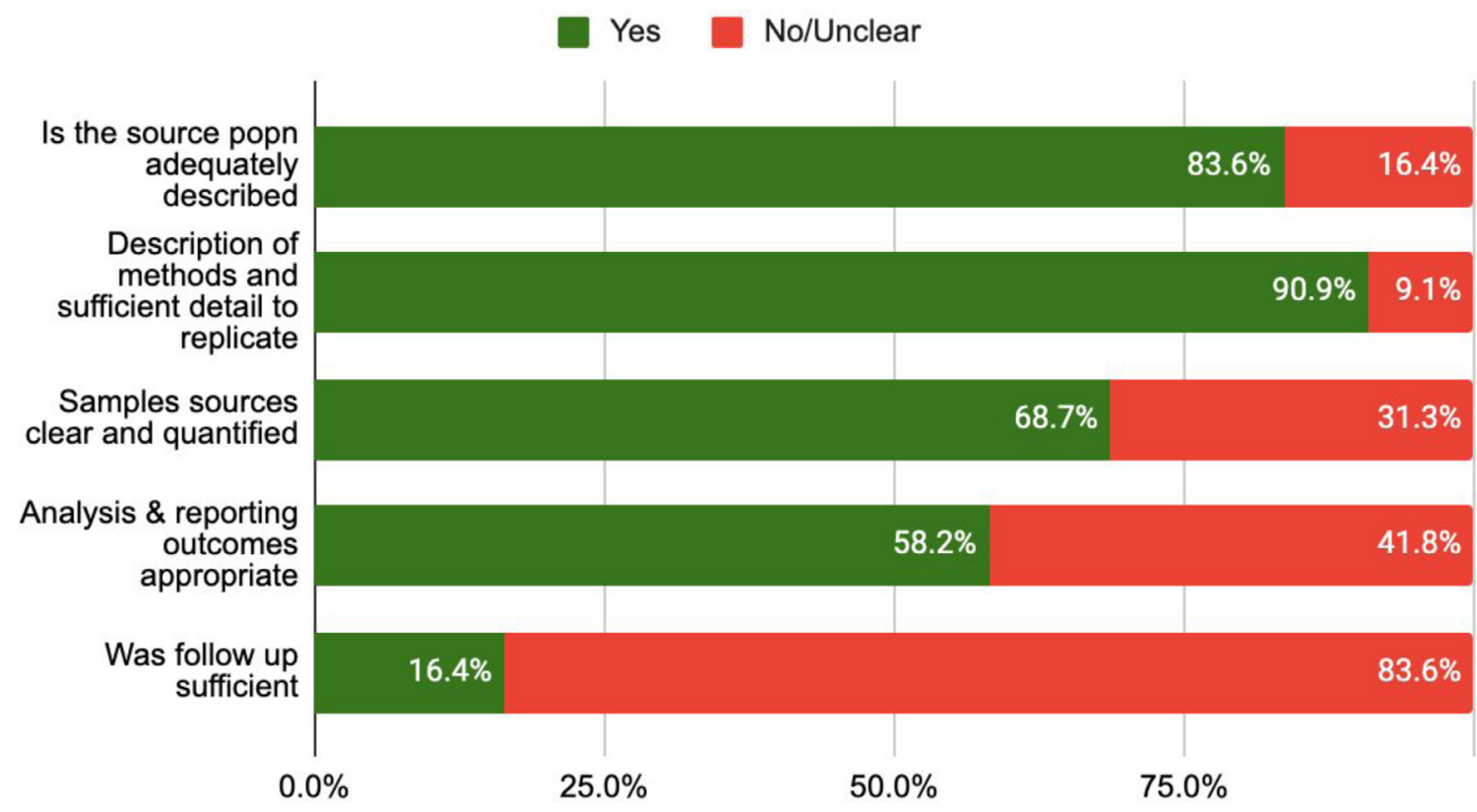

Figure 2. Risk of bias $(n=67)$.

Table 4. Concentrations of PCR samples recovered $(\mathbf{n}=\mathbf{2 5})$.

\begin{tabular}{|c|c|c|}
\hline Study $(n=64)$ & Cycle Threshold (Ct) & Copies per $\mathrm{m}^{3}$ (or L) \\
\hline Binder 2020 & $\begin{array}{l}\text { Sample at } 1.4 \mathrm{~m},<4 \mathrm{uM}: 1 \mathrm{st} 36.6 ; \text { 2nd } 37.1 \\
\text { Sample at } 2.2 \mathrm{~m},<4 \mathrm{uM}: 1 \mathrm{st} 37.4,2 \text { 2nd } 39.9 \\
\text { Sample at } 2.2 \mathrm{~m},>4 \mathrm{uM}: 1 \mathrm{st} 39.1 \text {, 2nd } 39.6\end{array}$ & \\
\hline Chia PY 2020 & & range $1.84 \times 10^{3}$ to $3.38 \times 10^{3}$ RNA copies per $\mathrm{m}^{3}$ \\
\hline Chirizzi D 2020 & & $<0.8$ copies $\mathrm{m}^{3}$ for each size range. \\
\hline Ding Z 2020 & & $\begin{array}{l}\text { RNA copies for weakly positive sample not } \\
\text { calculated. }\end{array}$ \\
\hline Dumont-Leblond N 2020 & $\begin{array}{l}\mathrm{N} \text { gene (range } 36.5 \text { to } 39.8 \text { ) mean } 38.0 \\
\text { ORF1b gene ( } 32.1 \text { to } 35.2 \text { ) mean } 33.7\end{array}$ & $\begin{array}{l}8 \text { positives for both } \mathrm{N} \text { and Orf1b (range } 9.9 \text { to } 514.2 \text { ) } \\
\text { mean } 201.6 \text { genomes } / \mathrm{m}^{3}\end{array}$ \\
\hline Feng B 2020 & & $\begin{array}{l}<1 \mu \mathrm{m}: 1,111 \text { copies } / \mathrm{m}^{3} \\
>4 \mu \mathrm{m}: 744 \text { copies } / \mathrm{m}^{3}\end{array}$ \\
\hline Ge XY 2020 & ICU: Ct $36.5-37.8$ & \\
\hline Guo ZD 2020 & $\begin{array}{l}\text { Indoor air near air outlet: Ct 35.7, } \\
\text { Near patients: Ct } 44.4 \text {. } \\
\text { Near the doctor's office area: Ct } 12.5\end{array}$ & $\begin{array}{l}\text { Indoor air near the air outlet: } 3.8 / \mathrm{L} \\
\text { near the patients: } 1.4 / \mathrm{L} \\
\text { near the doctor's office area: } 0.52\end{array}$ \\
\hline Horve PF 2020 & & $\begin{array}{l}\text { The highest abundance sample ( } 245 \text { gene copies) } \\
\text { found on the pre-filters, }\end{array}$ \\
\hline Hu J 2020 & & $\begin{array}{l}\text { range } 1.11 \times 10^{3} \text { to } 1.12 \times 104 \text { copies } \mathrm{m}^{3} \\
\text { In } 10 \% \text { of outdoor air samples, } 10 \mathrm{~m} \text { from the doors } \\
\text { of inpatient } \& \text { outpatient buildings range } 0.89 \text { to } \\
1.65 \times 10^{3} \text { copies } \mathrm{m}^{3}\end{array}$ \\
\hline Kenarkoohi A 2020 & $\begin{array}{l}\text { Ct around } 38 \text { for ORF1ab } \\
\text { Ct around } 35 \text { for } n \text { gene }\end{array}$ & \\
\hline
\end{tabular}




\begin{tabular}{|c|c|c|}
\hline Study $(n=64)$ & Cycle Threshold (Ct) & Copies per $\mathrm{m}^{3}$ (or $\mathrm{L}$ ) \\
\hline Lednicky JA 2020a & $\begin{array}{l}\text { Ct 36.0, 37.7, 37.4, 38.7, respectively (mean } \\
\text { Cq 37.5) }\end{array}$ & $\begin{array}{l}\text { Four positives contain: } 2.82 \mathrm{E}+03,9.12 \mathrm{E}+02 \\
1.15 \mathrm{E}+03,4.68 \mathrm{E}+02 \text { genome equivalents } 25 \mu \mathrm{L}\end{array}$ \\
\hline Lednicky JA 2020b & Ct 39.1 & 0.87 virus genome equivalents $L^{-1}$ \\
\hline Lei H 2020 & Near the head of the patient Ct 41.25 . & \\
\hline Liu Y \& Ning Z 2020 & & $\begin{array}{l}\text { ICU: rang- } 0-113 \text { copies } \mathrm{m}^{3} \\
\text { Patient areas } 0-19 \text { copies } \mathrm{m}^{3} \\
\text { Medical Staff Areas } 0-42 \mathrm{~m}^{3} \\
\text { Public areas: } 0-11 \text { copies } \mathrm{m}^{3}\end{array}$ \\
\hline Ma J 2020 & $\begin{array}{l}\text { Exhaled Breath Samples, } 14 \text { positives: } \mathrm{Ct} \\
35.5 \pm 3.2\end{array}$ & $\begin{array}{l}\text { Breath emission rate estimate: } 1.03 \times 10^{5} \text { to } \\
2.25 \times 10^{7} \text { viruses per hour. Air sample estimate } \\
6.1 \times 103 \text { viruses } / \mathrm{m}^{3}\end{array}$ \\
\hline Moreno T 2020 & & $\begin{array}{l}\text { genome count range } 14 \text { to } 446 / \mathrm{m} 2 \text { for IP2, } 9 \text { to } \\
490 / \mathrm{m}^{2} \text { for IP4 and } 5 \text { to } 378 / \mathrm{m} 2 \text { for } \mathrm{E} \text {. } \\
\text { Subway: } 1 \text { st sample estimate } 23.4 \mathrm{GC} / \mathrm{m}^{3}, 2 \text { nd } \\
\text { amplified target gene IP2 }\left(18.8 \mathrm{GC} / \mathrm{m}^{3}\right) \text { \& protein } \mathrm{E} \\
\left(5.6 \mathrm{GC} / \mathrm{m}^{3}\right) \text {. }\end{array}$ \\
\hline Nissen K 2020 & $\begin{array}{l}\text { Ct } N \text { gene: } 35.3 \\
\text { Ct E gene } 33.2 \\
\text { Ward } 1 \text { specimen Ct } 33.0 \text { for E gene only. }\end{array}$ & \\
\hline Orenes-Piñero E 2020 & $\begin{array}{l}\text { Ct from surfaces }>10 \text { cycles of those } \\
\text { obtained from the patient, indicating viral } \\
\text { load was lower in the room environment. }\end{array}$ & \\
\hline Razzini K 2020 & $\begin{array}{l}\text { ICU: Mean Ct } 22.6 \\
\text { Corridor: Mean Ct } 31.1\end{array}$ & \\
\hline Santarpia JL 2020a & & concentrations up to around 7.5 TCID $50 / \mathrm{m} 3$ of air. \\
\hline Santarpia JL 2020b & & $\begin{array}{l}\text { gene copies generally low and highly variable from } \\
\text { sample to sample ranging from } 0 \text { to } 1.75 \text { copies } / \mu \mathrm{L}\end{array}$ \\
\hline Seyyed Mahdi SM 2020 & & $\begin{array}{l}\text { Highest RNA concentrations observed between } \\
\text { beds } 6 \text { and } 7 \text { ( } 3,913 \text { copies per } \mathrm{ml} \text { ) }\end{array}$ \\
\hline Zhang D 2020 & & $\begin{array}{l}\text { Range } 285 \text { to } 1,130 \text { copies/m3. } \\
\text { Inside adjusting tank } 285 \text { copies/m3 and } 603 \\
\text { copies/m³. } \\
5 \mathrm{~m} \text { from Hospital outpatient building } 1,130 \text { copies/ } \\
\mathrm{m}^{3} \text {, } \\
5 \mathrm{~m} \text { from the inpatient building undetected }\end{array}$ \\
\hline Zhou J 2020 & & $\begin{array}{l}101 \text { to } 103 \text { copies of SARS-CoV-2 RNA in all air } \\
\text { samples; no significant difference between sample } \\
\text { areas. }\end{array}$ \\
\hline
\end{tabular}

Two studies conducted in hospitals also sampled other spaces. Liu Y \& Ning Z et al. reported 4/13 public areas were RT-PCR positive; Ma J et al. reported 1 positive sample from an unventilated quarantine hotel toilet room out of 26 samples taken. Zhang D et al. sampled the outdoor environment of three hospitals and reported 3/16 samples were RT-PCR positive. Lednicky JA 2020 b sampled in a respiratory infection evaluation area of a student health care center and reported one positive sample with a CT of 39 (virus genome equivalent of 0.87 virus genomes $\mathrm{L}^{-1}$ air).

Two studies reported on Exhaled Breath Condensate (EBC). Ma $\mathrm{J}$ et al. reported 14/52 EBC samples as RT-PCR positive and
Feng B et al. reported 2/8 positive EBC samples. Five studies conducted in hospitals did not attempt RT-PCR air sampling [Bays D 2020; McGain F 2020; Mponponsuo K 2020 Ogawa Y 2020 and Wong SCY 2020] In Lei H et al., it was not possible to separate air from surface sample results.

Outdoors and community. Seventeen studies reported on the outdoors and in the community (see Figure 1). These settings were buses (four studies: two in china [Luo K 2020 and Shen Y 2020]; one in Italy [Di Carlo P 2020] and one from Spain that included subway trains [Moreno T 2020]); two studies each for the outdoors; restaurant; choir practice \& block of flats, and one study each for a meat processing plant; home 
Table 5. The size of air particles in the sample $(n=8)$.

\begin{tabular}{|c|c|c|}
\hline Study $(n=64)$ & Samples Source & Size of air particles \\
\hline Binder 2020 & $\begin{array}{l}8 \text { National Institute for Occupational Safety and } \\
\text { Health (NIOSH) BC } 251 \text { Aerosol Samplers (Figure S3) } \\
\text { were placed } 1.5 \mathrm{~m} \text { from the ground, at } \sim 1 \text { meter, } \sim 1.4 \\
\text { meters, } \sim 2.2 \text { meters, and } \sim 3.2 \text { meters from the } \\
\text { SARS-CoV-2 patient's head and subsequently run for } \\
\sim 4 \text { hours. } 195 \text { air samples were collected }\end{array}$ & detected in aerosols particle size $<4 \mu \mathrm{m}$ \\
\hline Chia PY 2020 & $\begin{array}{l}\text { Air sampling was performed in three of the } 27 \\
\text { airborne infection isolation rooms (AIIRs). Bioaerosol } \\
\text { samplers used to collect air samples, set at a flow-rate } \\
\text { of } 3.5 \mathrm{~L} / \mathrm{min} \text { and run for four hours, collecting a total } \\
\text { of } 5,040 \mathrm{~L} \text { of air from each patient's room. }\end{array}$ & $\begin{array}{l}\text { positive particles of sizes }>4 \mu \mathrm{m} \text { and } 1-4 \mu \mathrm{m} \text { detected } \\
\text { in two rooms }\end{array}$ \\
\hline Chirizzi D 2020 & $\begin{array}{l}\text { The genetic material of SARS-CoV-2 (RNA) was } \\
\text { determined, using both real-time RT-PCR and ddPCR, } \\
\text { in air samples collected using PM10 samplers and } \\
\text { cascade impactors able to separate } 12 \text { size ranges } \\
\text { from nanoparticles (diameter D }<0.056 \mu \mathrm{m} \text { ) up to } \\
\text { coarse particles ( }>18 \mu \mathrm{m}) \text {. }\end{array}$ & $(\mathrm{D}<0.056 \mu \mathrm{m})$ up to coarse particles $(\mathrm{D}>18 \mu \mathrm{m})$ \\
\hline Feng B 2020 & $\begin{array}{l}\text { For a sampling of isolation room air, a NIOSH sampler } \\
\text { was placed on a tripod } 1.2 \mathrm{~m} \text { in height and } 0.2 \mathrm{~m} \text { away } \\
\text { from the bed at the side of the patient's head. The } \\
\text { sampling duration was } 30 \text { min, and a total of } 105-\mathrm{L} \\
\text { room air was sampled. ( } 9 \text { Exhaled Breath (EB) samples, } \\
8 \text { Exhaled Breath Condensate (EBC) samples, } 12 \\
\text { bedside air samples) }\end{array}$ & $\begin{array}{l}\text { RNA detected in the air sample in }<1 \mu \mathrm{m} \text { and }>4 \mu \mathrm{m} \\
\text { fractions, }\end{array}$ \\
\hline Hernández JL 2020 & $\begin{array}{l}\text { Air sampled in three areas: Emergency area (Clinic } \\
\text { A), Internal medicine (Clinic A), COVID } 19 \text { patient area } \\
\text { (Clinic A), and COVID-19 patients care room (Clinic } \\
\text { B). Sampling in all areas was accomplished in } 3 \text { h. } \\
\text { Filters of } 25 \text { mm diameter with } 0.22 \mu \text { m pores were } \\
\text { utilized (Millipore, AAWP02500), placed in a sterilized } \\
\text { filter holder (Millipore, SWINNX) coupled to a vacuum } \\
\text { system through a previously disinfected plastic hose, } \\
\text { filtering the air with a flow of } 9.6 \mathrm{~L} / \mathrm{min} \text { in each filter } \\
\text { holder. }\end{array}$ & filtration through $0.22 \mu \mathrm{m}$ pores. \\
\hline Liu Y \& Ning Z 2020 & $\begin{array}{l}\text { Over a } 2 \text { week period: } 30 \text { aerosol samples of total } \\
\text { suspended particles collected on } 25 \text {-mm-diameter } \\
\text { filters loaded into styrene filter cassettes (SKC) by } \\
\text { sampling air at a fixed flow rate of } 5.0 \text { I min-1 using a } \\
\text { portable pump (APEX2, Casella). Three size-segregated } \\
\text { aerosol samples collected using a miniature cascade } \\
\text { impactor (Sioutas Impactor, SKC) that separated } \\
\text { aerosols into five ranges ( }>2.5 \mu \mathrm{m}, 1.0 \text { to } 2.5 \mu \mathrm{m} \text {, } \\
0.50 \text { to } 1.0 \mu \mathrm{m} \text { and } 0.25 \text { to } 0.50 \mu \mathrm{m} \text { on } 25 \text {-mm filter } \\
\text { substrates, and } 0 \text { to } 0.25 \mu \mathrm{m} \text { on } 37 \text {-mm filters) at } \\
\text { a flow rate of } 9.0 \text { I min-1. Two aerosol deposition } \\
\text { samples collected using } 80 \text {-mm-diameter filters } \\
\text { packed into a holder with an effective deposition area } \\
\text { of } 43.0 \mathrm{~cm} 2 \text {; filters were placed intact on the floor in } \\
\text { two corners of an ICU for } 7 \text { days. }\end{array}$ & $\begin{array}{l}\text { SARS-CoV- } 2 \text { aerosols one in the submicrometre } \\
\text { region (dp between } 0.25 \text { and } 1.0 \mu \mathrm{m}) \text { and the other } \\
\text { in supermicrometre region }(\mathrm{dp}>2.5 \mu \mathrm{m}) \text {. Aerosols } \\
\text { in the submicrometre region were found with peak } \\
\text { concentrations of } 40 \text { and } 9 \text { copies } \mathrm{m} 3 \text { in the } 0.25-0.5 \\
\mu \mathrm{m} \text { and } 0.5-1.0 \mu \mathrm{m} \text { range, respectively. }\end{array}$ \\
\hline McGain F 2020 & $\begin{array}{l}\text { Two spectrometers to measure aerosol particles: } \\
\text { the portable Mini Wide Range Aerosol Sizer } 1371 \\
\text { (MiniWRAS) and the Aerodynamic Particle Sizer (APS). } \\
\text { During the procedure, the aerosol detector inlet was } \\
\text { positioned } 30 \mathrm{~cm} \text { directly above the patient's neck, } \\
\text { representing the surgeon's breathing air space }\end{array}$ & $\begin{array}{l}\text { APS detected larger aerosols }(>0.37 \mathrm{~mm}) \text { and } \\
\text { MiniWRAS smaller particles }(0.01-0.35 \mathrm{~mm}) \text {. }\end{array}$ \\
\hline
\end{tabular}




\begin{tabular}{|c|c|c|}
\hline Study (n=64) & Samples Source & Size of air particles \\
\hline Santarpia JL 2020a & $\begin{array}{l}\text { Air samplers were placed in various places in the } \\
\text { vicinity of the patient, including over } 2 \mathrm{~m} \text { distant. } \\
\text { Personal air sampling devices were worn by } \\
\text { study personnel on two days during sampling. } \\
\text { Measurements were made to characterize the size } \\
\text { distribution of aerosol particles, and size-fractionated, } \\
\text { aerosol samples were collected to assess the } \\
\text { presence of infectious virus in particles sizes of }>4.1 \\
\mu m, 1-4 \mu \mathrm{m} \text {, and }<1 \mu \mathrm{m} \text { in the patient environment. } \\
\text { An Aerodynamic Particle Sizer Spectrometer was } \\
\text { used to measure aerosol concentrations and size } \\
\text { distributions from } 0.542 \mu \mathrm{m} \text { up to } 20 \mu \mathrm{m} \text {. A NIOSH } \\
\text { BC251 sampler } 18 \text { was used to provide size segregated } \\
\text { aerosol samples for both } \mathrm{rRT} \text {-PCR and culture analysis. }\end{array}$ & $\begin{array}{l}\text { Two of the 1-4 } \mu \mathrm{m} \text { samples demonstrated viral } \\
\text { growth, between } 90 \% \text { and } 95 \% \text { confidence }\end{array}$ \\
\hline
\end{tabular}

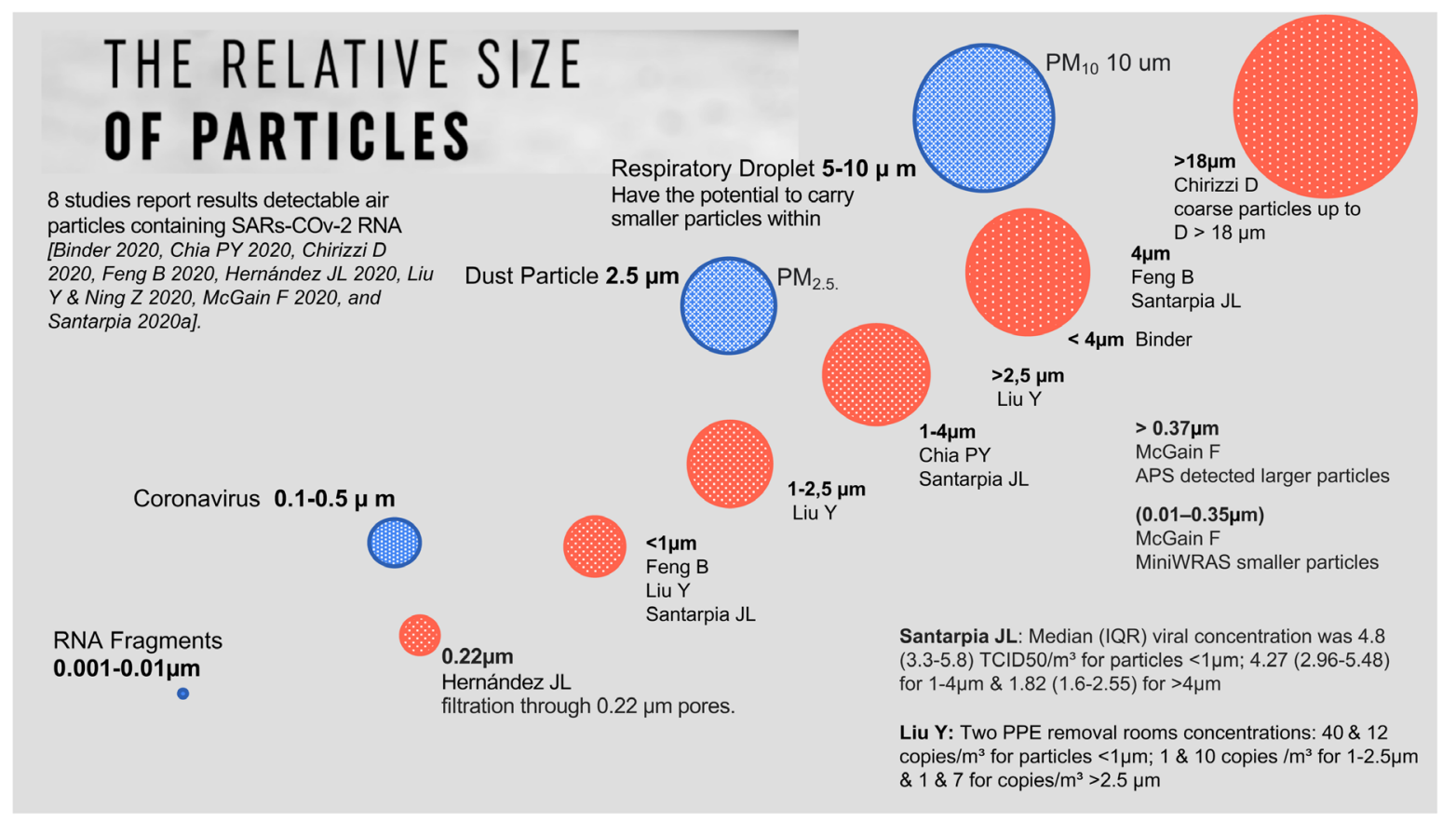

Figure 3. The relative size of particles.

residence; quarantine hotel; quarantined household and a care home.

Seven of these studies undertook RT-PCR sampling [Di Carlo P 2020: inside a bus; Dohla M 2020: quarantined households; Kang M 2020: a block of flats; Kwon KS 2020: the community; Moreno T 2020; buses and subway trains; Setti L 2020: outdoor sampling; and Wong JCC 2020: in the home residence], and one Chirizzi D 2020 sampled atmospheric concentrations.

Of the eight studies, two reported positive RT-PCR samples ( 5 of 125 samples positive for 2 or more genes, average $4.0 \%$ ), and one Chirizzi 2020 et al. found outdoor atmospheric concentrations of SARS-CoV-2 RNA at low levels <0.8 copies $\mathrm{m}^{3}$. Moreno 2020 et al. sampled on buses and subway trains in Barcelona, and reported samples were mainly positivity for only 1 of the 3 RNA targets, and Setti et al., in a study of outdoor sampling, reported 20/34 (59\%) Particulate Matter (PM) samples were RNA positive for one gene, and 4/34 (11.8\%) were positive for two genes (see Table 1). Five studies found no positive samples [Di Carlo P 2020: Dohla M 2020; Kang M 2020, Kwon KS 2020 and Wong JCC 2020].

Three studies reported on two choir practices and potential air transmission. Charlotte $\mathrm{N}$ et al. followed-up a choir practice in France with 27 participants who attended a choir practice on 
Red bars indicate studies sampling ICUs

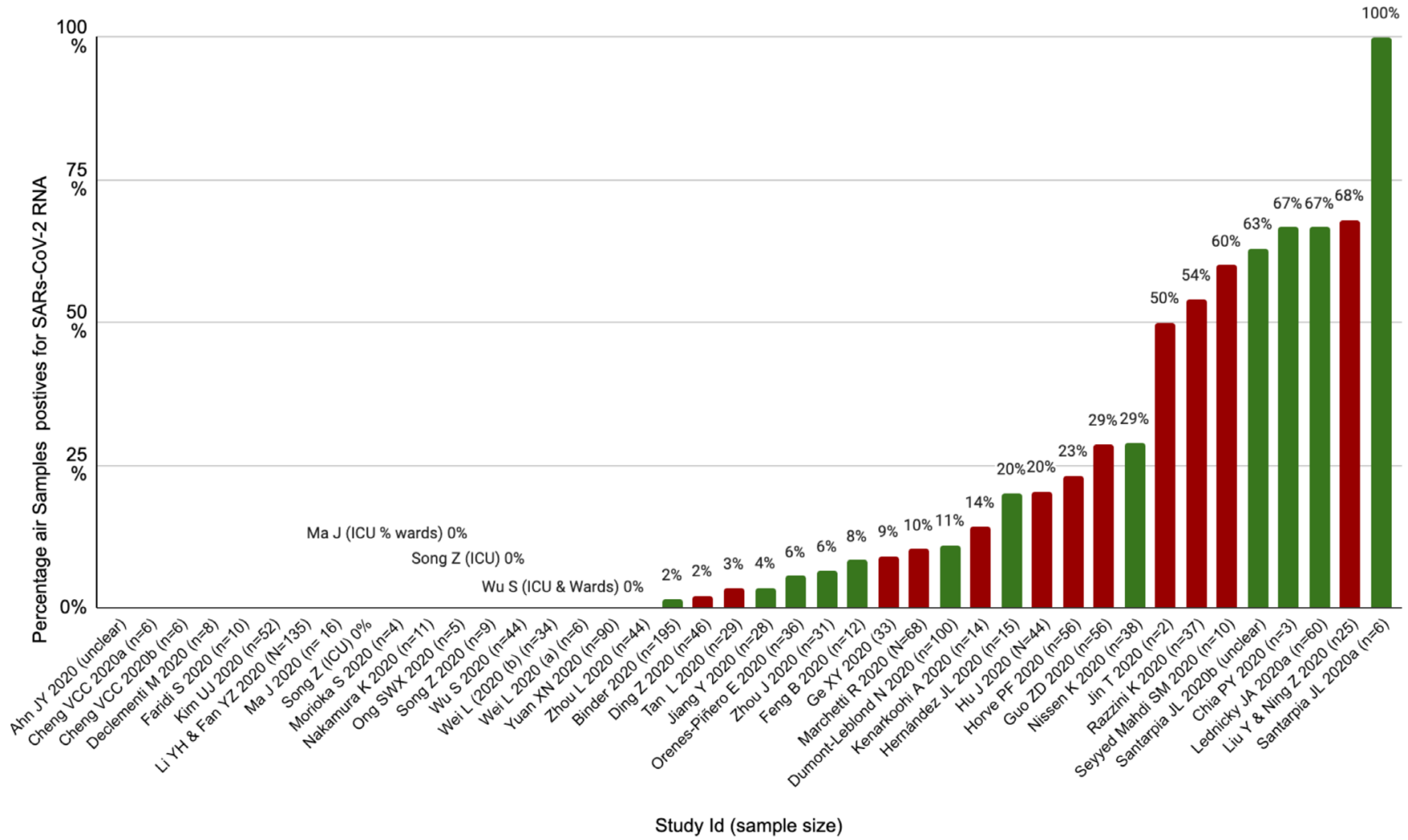

Figure 4. Percentage hospital air samples positive for SARs-CoV-2 RNA ( $\mathbf{n = 4 2}$ ). Red bars indicate studies sampling ICUs.

12 March 2020. Two separate publications [Hamner L 2020 and Miller SL 2020] published on the same Choir Practice Skagit County, Washington, USA. In total, 78 members attended two practices: $87 \%$ of choir members subsequently became ill (32 confirmed cases and 20 probable secondary cases).

Viral culture. Ten studies attempted viral culture [Binder 2020, Dohla M 2020, Dumont-Leblond N 2020, Hu J 2020, Lednicky JA 2020a, Lednicky JA 2020b, Nissen K 2020, Santarpia JL 2020a, Santarpia JL 2020b, Zhou J 2020]. In seven of the ten studies, the infectious virus could not be isolated and cytopathic effects could not be observed [Binder 2020, Dohla M 2020, Dumont-Leblond N 2020, Hu J 2020, Nissen K 2020, Santarpia JL 2020b and Zhou J 2020] (see Table 6).

Of the remaining three studies, Lednicky JA 2020b reported that general virus-induced cytopathic effects were observed within two days post-inoculation. The amount of virus present in $390 \mathrm{~L}$ of sampled air was low (approximately 340 virus genome equivalents). RT-PCR for SARS-CoV-2 RNA from the cell culture were negative, and three other respiratory viruses were identified: Influenza A H1N1, Influenza A H3N2, and human coronavirus $\mathrm{OC} 43$.

Lednicky JA 2020a observed presumed virus-induced CPE for 4/4 RNA-positive hospital air samples. The authors report that plaque assays could not be performed due to a nationwide non-availability of some critical media components in the USA. They also report that it took 6 to 11 days post-inoculation before rounding of the cells was observed with material collected by the air sampler and there is no report of a serial subculture of the positive air samples to demonstrate propagation of a complete replicating virus.

Santarpia JL 2020a reported 3/39 aerosol samples (particle size $<1 \mu \mathrm{m}$ ) that cell culture resulted in increased viral RNA at very low levels. An intact virus was observed via transmission electron microscopy in the submicron sample from one room. This study was published as a preprint (checked 5 March 2021) and is subject to methodological criticisms. Serial RT-PCR of cell culture supernatant was unclear and incongruent with the statement that some increase in viral RNA may have occurred. 


\section{Table 6. Viral culture methodological issues.}

\begin{tabular}{|l|l|}
\hline Study & Methodological \\
\hline Binder 2020 & $\begin{array}{l}\text { This study separated particles by three sizes: }>4 \mu \mathrm{m}, 1-4 \mu \mathrm{m}, \text { and }<1 \mu \mathrm{m} \text { and used multiple sampling sites } \\
\text { which is a robust sampling methodology. The median day's post symptom was reported as } 10 \text { with a range } \\
\text { of } 1 \text { to } 34 \text { days, and only one patient had a cycle threshold for the } \mathrm{N} \text { gene }<20 \text {. This limits the finding of any } \\
\text { cultivatable virus and the conclusions. }\end{array}$ \\
\hline All positive masks were subject to cell culture and inoculated with Vero-E6 cells after blind passage for three \\
generations which is a robust approach. One mask from a critically ill patient was positive for the virus but \\
no details on which passage and at what quantitative burden. The masks could have been contaminated by \\
saliva or nasal secretions and the conclusion stated that masks blocked the release of viable virus in the air \\
exhaled from the patient cannot be confirmed.
\end{tabular}

Santarpia JL 2020a and b

Zhou 2020
For Santapria 2020 (a) we could only find a preprint publication. A large number of samples were collected. Serial PCR of cell culture supernatant was unclear and incongruent with the statement that some increase in viral RNA may have occurred. Increased viral RNA presence is a surrogate and subject to many interpretations and should not be considered equal to the cultivation of replication and infection competent virus on cell culture which was not identified. Western blot assay was not done in cell supernatant samples with non-statistically significant evidence of replication, which would have acted as a control to ensure the findings were not spurious. Western blots are very weak, with no positive control or size markers and the signal doesn't necessarily come from a replicating virus, there's no "before culture" analysis.

The presence of virus-like particles on TEM is not proof that these are replicating viruses or necessarily even SAR-CoV-2. No comparisons to control TEM photomicrographs of the live virus from fresh Vero cells are presented to discuss.

No size-fractionation techniques were used to determine the size range of SARS-CoV-2 droplets and particles, raising major issues with the statement the data suggests that viral aerosol particles are produced by individuals that have the COVID-19.

No information is provided about activity by either patients or the doffing by health workers which may have contributed to hallway air samples being PCR positive. The contamination identified may have accumulated over the extended periods of occupancy and may represent the high frequency of reported PCR positive sites, Floor samples were most heavily reported which supports this finding. The numbers don't match up, Ct values were converted to pseudo TCID50 values based on an equation that obscures what Cts were actually recorded. Reporting $100 \%$ or $200 \%$ increases in RNA levels is actually only $2-3$ fold, and not the way viruses replicate (i.e. exponentially).

No plaques were reported to have been detected and no serial passage on subculture was reported. Statistical inferences are very difficult to interpret in Figure 1 based on the error bars. The broad sweeping conclusions that SARS-CoV-2 RNA exists in respired aerosols less than $5 \mu \mathrm{m}$ in diameter; that aerosols containing SARS-CoV-2 RNA exist in particle modes that are produced during respiration is difficult to justify based on the findings presented.

In Santarpia 2020 (b)There are "six patients in five rooms in two wards on three separate days in April of 2020" reported in the text. Table S1 reports are 6 rooms (2 are 7A and 7B and 4 are 5A-D). The abstract reports SARS-CoV-2 RNA was detected in all six rooms - It is therefore not clear whether there are 6 rooms or 5 - One room had 2 patients so the total could be 7 not 6 patients

There is no information in the patients and sampling is done $2-24$ days post 1 st covid test and looks like 4 were sampled less than 3 days post first covid test but there is no information of symptom onset. No ct values were provided on the testing of the pts when first done. A Ct of 45 for E gene is not considered a usual standard and much higher than what most labs use and accept and a lot of background "noise" as a result

It is likely an equation as used to calculate the concentration of the virus, however, it is more robust to measure the virus directly than use an equation. EM also does not confirm live virus and does not indicate active viral replication as the authors suggest - where are the comparisons control EM photomicrographs.

No indication any particle size-fractionation techniques were used to determine the size range of droplets and particle differentiation in air sampling. No information on patients is provided and it is possible they were in the later stages of illness when no virus could be reliably cultivated. All surface and air samples from the hospital environment had a Ct value $>30$, in a range where it is extremely difficult to cultivate the virus. No attempt was made to ensure the sampler was placed at a specific distance from the individuals.
(Wang W, Xu Y 2020 and (Xiao F, Sun J 2020)
Electron microscopy alone does not proof of an infectious virus. Inactivated particles would look the same, and images weren't provided in these studies. 
No size-fractionation techniques were used to determine the size range of SARS-CoV-2 droplets and particles. (Table 7 sets out several methodological issues relating to viral culture).

\section{Discussion}

We identified 67 primary studies, all were observational and low quality. The results show that RT-PCR RNA can be detected sporadically in airborne samples in a variety of settings. About half the studies did not detect RNA positivity. Some of the reasons for this may be methodological weaknesses in the study design, the lack of validated methods and the location and variable distance of the sampling. There was no clear relationship between the type of setting and positivity of sampling or detectable viral RNA concentrations. The reporting of viral RNA concentrations was heterogeneous as were the sampling methods.

Past attempts to detect infectious particles have proved difficult: aerosols are dilute and culturing fine particles is problematic. In a NEJM editorial, Roy et al., report 'the only clear proof that any communicable disease is transmitted by aerosol came from the famous experiment by Wells, Riley, and Mills in the 1950s, which required years of continual exposure of a large colony of guinea pigs to a clinical ward filled with patients who had active tuberculosis ${ }^{11}$.' A 2019 review reported that viral RNA or DNA, depending on the virus, could be found in the air near patients with influenza, respiratory syncytial virus, adenovirus, rhinovirus, and other coronaviruses but rarely reported viable viruses ${ }^{12}$. For coronaviruses, previous evidence supporting the airborne route of transmission is weak ${ }^{13}$.

Several studies included in our systematic review and reported in the tables, do not support the airborne transmission hypothesis. An included US study performed active case finding from two index patients and 421 exposed HCWs [Bays D 2020]. Eight secondary infections in HCWs were reported, but despite multiple aerosol-generating procedures, there was no evidence of airborne transmission. No transmission events were found in multiple high-risk exposures from five symptomatic COVID-19 health care workers [Mponponsuo K 2020]; Wong SCY et al. reported none of 120 contacts of a patient with initially undetected Covid-19 subsequently became infectious, and Kim UJ et al. reported that all 52 air samples were negative for SARS-CoV-2 RNA.

\section{Strengths and limitations}

There is a current lack of well-conducted studies addressing airborne transmission: only nine studies identified during the search period reported air sampling outdoors and, in the environment, outside of hospitals. The findings of our review are limited by the low-quality included studies that lack standardised methods, reporting and outcomes. The small sample sizes, the absence of study protocols and the lack of replication further undermine the findings. Sporadic isolation of viral RNA may be due to problems with sampling techniques. Lack of quality is noted across several of the airborne reviews. Furthermore, while our search was comprehensive, it is likely there are studies that we have missed. Our continual updating and scoping of the literature mean we intend to update this review as more studies and evidence become available.

Evidence from the referenced systematic reviews noted the need to improve the quality of evidence. Anderson et al. reported the need for further data collection under differing conditions of temperature and humidity ${ }^{14}$. Carducci et al. considered no studies had sufficient confirmatory evidence, and only a hypothesis supports airborne transmission ${ }^{15}$, Schünemann et al. noted direct studies in COVID-19 are limited and poorly reported ${ }^{16}$, and Mousavi et al. noted the need for rigorous and feasible lines of research in the area of air filtration and recirculation in healthcare facilities ${ }^{17}$.

Future studies are warranted to verify findings (particularly including viral culture) before conclusions can be reached about a mode of transmission and important knowledge such as infectious dose. Because of the heterogeneity of the settings, the case-mix limitations, the sampling techniques used clear descriptions and variable study protocols, it is difficult to make meaningful comparisons of air sampling positivity or viral concentrations between settings. Many factors including relative humidity, temperature, aerosolization medium, exposure period, the chemical composition of the air, seasonality, sampling methods, and ultraviolet light exposure can affect the potential infectivity of airborne viruses. While sampling techniques have improved greatly over time, the lack of standardization requires addressing as it limits the development of general recommendations for the sampling of airborne viruses ${ }^{18}$.

One essential question is whether observed epidemiologic associations are causal ${ }^{19,20}$. Establishing transmission modes requires integrated epidemiological and mechanistic approaches to narrow uncertainty ${ }^{21}$. Transmission evidence should be contextspecific to particular settings (i.e., indoor or outdoor), environment-specific (i.e., the presence of UV light. ventilation etc.) and ensure that exposure an infectious agent has taken place. Identifying those circumstances that promote transmission using all types of relevant evidence that are more likely to promote viral transmission, and therefore, more amenable to intervention.

Methodological issues of the culture methods used, as well as knowledge of the infectiousness of the patient hinder interpretation and suggest that the results should be interpreted with caution. The detection of SARS-CoV-2 RNA in the air cannot presume transmission, since only viable virions can cause disease. No airborne study to date definitively demonstrates SARS-CoV-2 is of an infectious nature, which offers the most robust evidence of transmissibility ${ }^{22}$. CPE alone cannot be relied upon to establish SARS-CoV-2 replication and additional methods are required, including demonstration of viral growth on permissive cell lines, immunofluorescence staining, and confirmed the exclusion of other pathogens or contaminants with sequence confirmation. General virus-induced cytopathic effects were observed in one study, however, RT-PCR tests for SARS-CoV-2 were negative while three other respiratory viruses were identified ${ }^{23}$. 
Table 7. Live culture results $(\mathbf{n = 1 0})$.

\begin{tabular}{|c|c|c|c|c|c|}
\hline $\begin{array}{l}\text { Study } \\
(n=64)\end{array}$ & Setting & Method & $\begin{array}{l}\text { Air Samples } \\
\text { positive } n / d \text { for } \\
\text { SARs-CoV-2 RNA }\end{array}$ & Live culture & Notes \\
\hline Binder 2020 & Hospital & $\begin{array}{l}\text { An observational case } \\
\text { series of } 20 \text { patients } \\
\text { hospitalized with } \\
\text { coronavirus disease }\end{array}$ & $\begin{array}{l}3 / 195 \text { samples } \\
\text { from } 3 \text { patients }\end{array}$ & $0 / 3$ viable virus & \\
\hline $\begin{array}{l}\text { Dohla M } \\
2020\end{array}$ & $\begin{array}{l}\text { Quarantined } \\
\text { households }\end{array}$ & $\begin{array}{l}\text { An observational } \\
\text { study of } 43 \text { adults } \\
\text { and } 15 \text { children living } \\
\text { in } 21 \text { households; } \\
\text { air (also surface and } \\
\text { wastewater) samples } \\
\text { taken. }\end{array}$ & $0 / 15$ & $\begin{array}{l}\text { The infectious virus } \\
\text { could not be isolated } \\
\text { in Vero E6 cells from } \\
\text { any environmental } \\
\text { sample. }\end{array}$ & $\begin{array}{l}26 \text { of all } 43 \text { tested adults } \\
\text { were positive by RT-PCR. } \\
10 \text { of } 66 \text { wastewater } \\
\text { samples and } 4 / 119 \text { surface } \\
\text { swab samples were } \\
\text { positive for SARS-CoV-2 }\end{array}$ \\
\hline $\begin{array}{l}\text { Dumont- } \\
\text { Leblond N } \\
2020\end{array}$ & Hospital & $\begin{array}{l}\text { An observational } \\
\text { study in acute care } \\
\text { hospital rooms over } \\
\text { the course of nearly } \\
\text { two months }\end{array}$ & $\begin{array}{l}11 / 100 \text { from } 6 \\
\text { patient rooms }\end{array}$ & $\begin{array}{l}\text { Viral cultures were } \\
\text { negative }\end{array}$ & \\
\hline Hu J 2020 & Hospital & $\begin{array}{l}\text { An observational } \\
\text { study: indoor and } \\
\text { outdoor air samples } \\
\text { in ICUs and CT rooms }\end{array}$ & $\begin{array}{l}\text { aerosol samples } \\
8 / 38 \text { from ICUs } \\
1 / 6 \text { from CT } \\
\text { rooms } \\
\text { samples from } \\
\text { medical staff } \\
\text { rest areas and } \\
\text { corridors were } \\
\text { all negative } \\
\text { (denominator not } \\
\text { clear) }\end{array}$ & $\begin{array}{l}\text { All positive aerosol } \\
\text { samples were } \\
\text { negative after three } \\
\text { passages of Vero-E6 } \\
\text { cells inoculated in a } \\
\text { blind test. }\end{array}$ & $\begin{array}{l}\text { All positive masks were } \\
\text { subjected to cell culture } \\
\text { and inoculated with Vero- } \\
\text { E6 cells after blind passage } \\
\text { for three generations. One } \\
\text { mask from a critically ill } \\
\text { patient detected positive. }\end{array}$ \\
\hline $\begin{array}{l}\text { Lednicky JA } \\
\text { 2020a }\end{array}$ & Hospital & $\begin{array}{l}\text { Observational: air } \\
\text { samples collected, } \\
\text { and virus culture } \\
\text { attempted }\end{array}$ & $\begin{array}{l}4 / 4 \text { air samples } \\
\text { without a HEPA } \\
\text { filter } \\
\text { 0/2 samples using } \\
\text { a HEPA filter }\end{array}$ & $\begin{array}{l}\text { Virus-induced } \\
\text { CPEwas observed for } \\
4 / 4 \text { RNA-positive air } \\
\text { samples. }\end{array}$ & $\begin{array}{l}\text { No other respiratory } \\
\text { virus was identified in the } \\
\text { samples using a BioFire } \\
\text { FilmArray Respiratory } \\
2 \text { Panel. The amount of } \\
\text { airborne virus detected } \\
\text { per litre of air was small. } \\
\text { Plaque assays could not } \\
\text { be performed due to a } \\
\text { nationwide nonavailability } \\
\text { of some critical media } \\
\text { components (due to } \\
\text { covID-19 pandemic- } \\
\text { related temporary } \\
\text { lockdown of production } \\
\text { facilities), so TCID50 } \\
\text { assays were performed in } \\
\text { Vero E6 cells to estimate } \\
\text { the percentage of the } \\
\text { collected virus particles } \\
\text { that were viable. Estimates } \\
\text { ranged from } 2 \text { to } 74 \\
\text { TCID50 units/L of air }\end{array}$ \\
\hline $\begin{array}{l}\text { Lednicky JA } \\
\text { 2020b }\end{array}$ & $\begin{array}{l}\text { Student } \\
\text { Healthcare } \\
\text { centre }\end{array}$ & $\begin{array}{l}\text { Observational, air } \\
\text { samples collected, } \\
\text { and virus culture } \\
\text { attempted }\end{array}$ & $1 / 2$ air samples & $\begin{array}{l}\text { General virus- } \\
\text { induced cytopathic } \\
\text { effects were } \\
\text { observed within two } \\
\text { days post-inoculation }\end{array}$ & $\begin{array}{l}\text { Estimated concentration } \\
\text { of } 0.87 \text { virus genomes } \\
\text { L-1 air. The amount of } \\
\text { virus present in } 390 \mathrm{~L} \\
\text { of sampled air was low } \\
\text { (approximately } 340 \text { virus } \\
\text { genome equivalents). } \\
\text { PCR tests for SARS-CoV-2 } \\
\text { VRNA from cell culture } \\
\text { were negative. Three } \\
\text { respiratory viruses were } \\
\text { identified using the Biofire } \\
\text { RVP: Influenza A H1N1, } \\
\text { Influenza A H3N2, and } \\
\text { Human coronavirus OC43 }\end{array}$ \\
\hline
\end{tabular}




\begin{tabular}{|c|c|c|c|c|c|}
\hline $\begin{array}{l}\text { Study } \\
(n=64)\end{array}$ & Setting & Method & $\begin{array}{l}\text { Air Samples } \\
\text { positive n/d for } \\
\text { SARs-CoV-2 RNA }\end{array}$ & Live culture & Notes \\
\hline $\begin{array}{l}\text { Nissen K } \\
2020\end{array}$ & Hospital & $\begin{array}{l}\text { Observational: surface } \\
\text { swabs and fluid } \\
\text { samples collected, } \\
\text { and experimental: } \\
\text { virus culture was } \\
\text { attempted. }\end{array}$ & $\begin{array}{l}\text { 7/19 filter were } \\
\text { positive } \\
11 \text { days later, } 4 / 19 \\
\text { were positive for } \\
\text { both genes. }\end{array}$ & $\begin{array}{l}\text { No significant CPE } \\
\text { was seen after three } \\
\text { passages on Vero E6 } \\
\text { cells from samples } \\
\text { retrieved from ward } \\
\text { vent openings or } \\
\text { central ventilation } \\
\text { ducts or filters }\end{array}$ & $\begin{array}{l}\text { Cycle threshold (Ct) values } \\
\text { varied between } 35.3 \\
\text { and } 39.8 \text { for the } N \text { and } \mathrm{E} \\
\text { gene. Virus culture was } \\
\text { attempted: RNA detected } \\
\text { in sequential passages but } \\
\text { CPE not observed. }\end{array}$ \\
\hline $\begin{array}{l}\text { Santarpia } \\
\text { JL 2020a }\end{array}$ & Hospital & $\begin{array}{l}\text { Observational: size- } \\
\text { fractionated aerosol } \\
\text { samples collected; } \\
\text { experimental: } \\
\text { virus culture was } \\
\text { attempted. }\end{array}$ & $\begin{array}{l}6 / 6 \text { patient } \\
\text { rooms. }\end{array}$ & $\begin{array}{l}\text { In } 3 \text { aerosol samples } \\
\text { size }<1 \mu \text { m, cell } \\
\text { culture resulted in } \\
\text { increased viral RNA. } \\
\text { Viral replication } \\
\text { of aerosol was } \\
\text { observed in the } 1 \\
\text { to } 4 \mu \text { m size but did } \\
\text { not reach statistical } \\
\text { significance. }\end{array}$ & $\begin{array}{l}\text { The presence of SARS- } \\
\text { CoV- } 2 \text { was observed via } \\
\text { western blot for all but one } \\
\text { of the samples }(<1 \text { um, } \\
\text { with statistically significant } \\
\text { evidence of replication, by } \\
\text { rRT-PCR. The intact virus } \\
\text { was observed via TEM in } \\
\text { the submicron sample } \\
\text { from Room. }\end{array}$ \\
\hline $\begin{array}{l}\text { Santarpia } \\
\text { JL 2020b }\end{array}$ & $\begin{array}{l}\text { Healthcare } \\
\text { centre }\end{array}$ & $\begin{array}{l}\text { Observational: high- } \\
\text { volume (50 Lpm) and } \\
\text { low-volume (4 Lpm) } \\
\text { personal air samples } \\
\text { (\& surface samples) } \\
\text { collected from } 13 \\
\text { Covid-19 patients; } \\
\text { experimental: } \\
\text { virus culture was } \\
\text { attempted. }\end{array}$ & $\begin{array}{l}63 \% \text { of in-room } \\
\text { air samples } \\
\text { positive } \\
\text { (denominator } \\
\text { unclear) }\end{array}$ & $\begin{array}{l}\text { Due to the low } \\
\text { concentrations } \\
\text { recovered in the } \\
\text { samples cultivation } \\
\text { of the virus was not } \\
\text { confirmed in these } \\
\text { experiments. }{ }^{*}\end{array}$ & $\begin{array}{l}\text { Partial evidence of virus } \\
\text { replication from one air } \\
\text { sample. In the NBU, for } \\
\text { the first two sampling } \\
\text { events performed on } \\
\text { Day } 10 \text {, the sampler was } \\
\text { placed on the window } \\
\text { ledge away from the } \\
\text { patients and was positive } \\
\text { for RNA ( } 2.42 \text { copies/L of } \\
\text { air). On Day } 18 \text { in NBU } \\
\text { Room B occupied by } \\
\text { Patient } 3 \text {, one sampler was } \\
\text { placed near the patient } \\
\text { and one was placed near } \\
\text { the door greater than } 2 \\
\text { meters from the patient's } \\
\text { bed while the patient } \\
\text { was receiving oxygen ( } 1 \mathrm{~L} \text { ) } \\
\text { via nasal cannula. Both } \\
\text { samples were positive by } \\
\text { PCR, with the one closest } \\
\text { to the patient indicating } \\
\text { a higher airborne } \\
\text { concentration of RNA } \\
\text { (4.07 as compared to } 2.48 \\
\text { copies/L of air). }\end{array}$ \\
\hline Zhou J 2020 & Hospital & $\begin{array}{l}\text { Observational: (air } \\
\text { \& surface) samples } \\
\text { collected from a } \\
\text { hospital with a high } \\
\text { number of Covid-19 } \\
\text { inpatients. }\end{array}$ & $\begin{array}{l}\text { 2/31 air samples } \\
\text { positive } \\
\text { 12/31 suspected }\end{array}$ & $0 / 14$ & $\begin{array}{l}\text { We defined samples, } \\
\text { where both of the PCRs } \\
\text { performed from an air or } \\
\text { surface sample, detected } \\
\text { SARS-CoV-2 RNA as } \\
\text { positive, and samples } \\
\text { where one of the two PCRs } \\
\text { performed from an air or } \\
\text { surface sample detected } \\
\text { SARS-CoV-2 RNA as } \\
\text { suspected }\end{array}$ \\
\hline
\end{tabular}




\section{Conclusion}

SARS-COV-2 RNA can be detected intermittently by RT-PCR in the air in a variety of settings. A number of studies that looked for viral RNA in air samples found none, even in settings where surfaces were found to be contaminated with SARS-CoV-2 RNA. The lack of recoverable viral culture samples of SARS-CoV-2 prevents firm conclusions to be drawn about airborne transmission. The current evidence is low quality, and there is an urgent need to standardise methods and improve reporting.

\section{Data availability}

Underlying data

All data underlying the results are available as part of the article and no additional source data are required.

\section{Extended data}

Figshare: SARS-CoV-2 and the Role of Airborne Transmission: Systematic review, https://doi.org/10.6084/m9.figshare.14248055. $\mathrm{v} 2^{7}$.

This project contains the following extended data:

- Appendix 1: Updated protocol
- Appendix 2: Search strategy

- Appendix 3: References of included studies

- Appendix 4: Sampling methods

Reporting guidelines

Figshare: PRISMA checklist for 'SARS-CoV-2 and the role of airborne transmission: a systematic review', https://doi.org/ 10.6084/m9.figshare.14248055.v27.

Data are available under the terms of the Creative Commons Attribution 4.0 International license (CC-BY 4.0).

\section{Acknowledgements}

This work was commissioned and paid for by the World Health Organization (WHO). Copyright on the original work on which this article is based belongs to WHO. The authors have been given permission to publish this article. The author(s) alone is/are responsible for the views expressed in the publication. They do not necessarily represent views, decisions, or policies of the World Health Organization.
1. WHO: Transmission of SARS-CoV-2: implications for infection prevention precautions. Scientific Brief. Reference Source

2. Hinds WC]: Aerosol Technology. John Wiley and Sons. 1982; 424. Reference Source

3. Wells WF: ON AIR-borne infection: study II. Droplets and droplet nuclei. $A m$ J Epidemiol. 1934; 20: 611-618.

Publisher Full Text

4. Kutter JS, Spronken MI, Fraaij PL, et al.: Transmission routes of respiratory viruses among humans. Curr Opin Virol. 2018; 28: 142-151. PubMed Abstract | Publisher Full Text | Free Full Text

5. Tellier R, Li Y, Cowling BJ, et al.: Recognition of aerosol transmission of infectious agents: A commentary. BMC Infect Dis. 2019; 19(1): 101 PubMed Abstract | Publisher Full Text | Free Full Text

6. Transmission of SARS-CoV-2: implications for infection prevention precautions. Reference Source

7. Heneghan C, Spencer E, Plüddemann A, et al:: SARS-CoV-2 and the Role of Airborne Transmission: Systematic review. figshare. Dataset. 2021. http://www.doi.org/10.6084/m9.figshare.14248055.v2

8. Whiting PF, Rutjes AW, Westwood ME, et al.: QUADAS-2 Group. QUADAS-2: a revised tool for the quality assessment of diagnostic accuracy studies. Ann Intern Med. 2011; 155(8): 529-36. PubMed Abstract | Publisher Full Text

9. Savvides C, Siegel R: Asymptomatic and presymptomatic transmission of SARS-CoV-2: A systematic review. medRxiv. 2020; 2020.06.11.20129072. PubMed Abstract | Publisher Full Text | Free Full Text

10. Mahtani KR, Jefferson T, Heneghan C, et al.: What is a 'complex systematic review'? Criteria, definition, and examples. BMJ Evid Based Med. 2018; 23(4): 127-130.

PubMed Abstract | Publisher Full Text

11. Roy CJ, Milton DK: Airborne transmission of communicable infection-the elusive pathway. N EnglJ Med. 2004; 350(17): 1710-1712. PubMed Abstract | Publisher Full Text

12. Shiu EYC, Leung NHL, Cowling B]: Controversy around airborne versus droplet transmission of respiratory viruses: implication for infection prevention. Curr Opin Infect Dis. 2019; 32(4): 372-379. PubMed Abstract | Publisher Full Text

13. Herfst $\mathrm{S}$, Böhringer $\mathrm{M}$, Karo $\mathrm{B}$, et al.: Drivers of airborne human-to-human pathogen transmission. Curr Opin Virol. 2017; 22: 22-29. PubMed Abstract | Publisher Full Text | Free Full Text

14. Anderson EL, Turnham P, Griffin IR, et al.: Consideration of the Aeroso Transmission for COVID-19 and Public Health. Risk Anal. 2020; 40(5): 902-07.

PubMed Abstract | Publisher Full Text | Free Full Text

15. Carducci A, Federigi I, Verani M: Covid-19 Airborne Transmission and Its Prevention: Waiting for Evidence or Applying the Precautionary Principle? Atmosphere. 2020; 11(7): 710. Publisher Full Text

16. Schünemann $\mathrm{HJ}$, Khabsa J, Solo K, et al.: Ventilation techniques and risk for transmission of coronavirus disease, including COVID-19: a living systematic review of multiple streams of evidence. Ann Intern Med. 2020; 173(3): 204-216.

PubMed Abstract | Publisher Full Text | Free Full Text

17. Mousavi EH, Kananizadeh N, Martinello RA, et al.: CovID-19 Outbreak and Hospital Air Quality: A Systematic Review of Evidence on Air Filtration and Recirculation. Environ Sci Technol. 2020; acs.est.0c03247. PubMed Abstract | Publisher Full Text | Free Full Text

18. Verreault $D$, Moineau $S$, Caroline $D$ : Methods for sampling of airborne viruses. Microbiol Mol Biol Rev. 2008; 72(3): 413-44. PubMed Abstract | Publisher Full Text | Free Full Text

19. Howick J, Glasziou P, Fau - Aronson JK, et al.: The evolution of evidence hierarchies: what can Bradford Hill's 'guidelines for causation' contribute? $R$ Soc Med. 2009; 102(5): 186-94.

PubMed Abstract | Publisher Full Text | Free Full Text

20. Hill AB: The Environment and Disease: Association or Causation? Proc $R$ Soc Med. 1965; 58(5): 295-300.

PubMed Abstract | Publisher Full Text | Free Full Text

21. Tellier R, Li Y, Cowling BJ, et al.: Recognition of aerosol transmission of infectious agents: a commentary. BMC Infect Dis. 2019; 19(1): 101. PubMed Abstract | Publisher Full Text | Free Full Text

22. Jefferson T, Spencer EA, Brassey J, et al: Viral cultures for COVID-19 infectious potential assessment - a systematic review. Clin Infect Dis. 2020; ciaa1764. PubMed Abstract | Publisher Full Text | Free Full Text

23. Lednicky JA, Shankar SN, Elbadry MA, et al.: Collection of SARS-CoV-2 Virus from the Air of a Clinic within a University Student Health Care Center and Analyses of the Viral Genomic Sequence. Aerosol Air Qual Res. 2020; 20(6): 1167-1171.

PubMed Abstract | Publisher Full Text | Free Full Text 


\section{Open Peer Review}

\section{Current Peer Review Status: $\mathrm{X}$ ? $\mathrm{X}$}

\section{Version 1}

Reviewer Report 05 May 2021

https://doi.org/10.5256/f1000research.55319.r82052

(C) 2021 Yao M. This is an open access peer review report distributed under the terms of the Creative Commons Attribution License, which permits unrestricted use, distribution, and reproduction in any medium, provided the original work is properly cited.

\section{Maosheng Yao \\ College of Environmental Sciences and Engineering, Peking University, Beijing, China \\ Review for Heneghan et al. (2021), SARS-CoV-2 and the role of airborne transmission: a systematic review, F1000Research 2021, 10:232.}

First, I have to declare that this review is provided solely based on scientific evidence and reasoning without any discipline preferences or conflicting interests. Despite not being exhaustive, I have to greatly applaud the efforts of all the authors for developing this review, especially the compiling of relevant COVID-19 aerosol related articles. However, to me this review serves as a perfect piece for evidence compiled for probable airborne transmission of COVID-19 if the biased discussion and preferences of content inclusion are eliminated/avoided. Thus, I feel this review, if to be indexed, needs to completely change the tone, and better suited for an article with a title like: Evidences for probable aerosol transmission of COVID-19: a systematic review. For its current form, there are many problematic issues with this review, and the discussion is also biased.

\section{Major comments are listed below:}

1. This review is commissioned and supported by the WHO (World Health Organization) which has clearly stated in March 2020 that COVID-19 is not airborne. An effort supported by the WHO is hardly believed to use to overturn its own statements or harm its authority. Thus, the authors should provide documents that can demonstrate such potential conflicting interests can be sufficiently cleared. Otherwise, I can only say that this review just serves as a proxy of the WHO for its statements with a biased science provided.

2. The aerosol definition was not effectively or properly communicated. For example, in the Introduction, they state that "aerosol particle ranges from $0.001 \mu \mathrm{m}$ to over $100 \mathrm{~mm}$ ". Are they sure that there are $10 \mathrm{~cm}(100 \mathrm{~mm})$ aerosol particles in the air? In case they mistyped the unit, e.g., $100 \mu \mathrm{m}$ should be used. Experimental data in many studies (they did not cite) show that major fraction of exhaled particles during breathing or speaking in controlled and real world scenarios are smaller than $5 \mu \mathrm{m}$, and sometimes they peak at $1 \mu \mathrm{m}$. Most recently, US CDC states 
that surface contact transmission of COVID-19 is minimal (the authors should certainly update the review). Therefore, how do the authors explain the COVID-19 transmission between people? They might attribute the droplet transmission. But, airborne droplet is an aerosol by definition. The review did not provide any data for droplet transmission. Instead, they have provided a lot of studies that have detected SARS-CoV-2 in aerosol particles.

3. This review lacks a significant amount of discussion of aerosol physics (very important) in terms with aerosol transmission of COVID-19. For example, a lot of studies they provided used a filter to sample air, and it is known that filtration itself can cause desiccation which affects the integrity of biological cells/particles over a prolonged time period. Accordingly, it partially attributed to low recovery of viable SARS-CoV-2 virus. For impaction or liquid based studies, the sampling velocity could also damage the integrity of the viruses, e.g., the BioSampler has an impact velocity of up to $300 \mathrm{~m} / \mathrm{s}$ by calculation, which would somehow damage the virus. Besides, when the viruses are released into the air, they would be rapidly diluted and transported away given any ventilation of either natural or mechanical nature is present. Thus, the airborne viral concentration level is time, ventilation, and space dependent. The aging of the virus in the air also affect its viability. In addition, the in vitro viability tests with cells can not be directly translated back to the infection of human cells inside the body where the overall physiological environment is different, and more favorable for viral replication. So far, no studies have demonstrated that those in vitro tested noninfectious viruses cannot infect humans. Human inhalation takes place at a rate of about $12 \mathrm{~L} / \mathrm{min}$, which is relatively gentle in terms of sampling stress on the virus. Therefore, their argument that lack of recovery of viable virus prevents a firm conclusion of airborne transmission of COVID-19 is not supported by their reasoning and existing data. Instead, many outbreaks or infections are difficult to explain without referring to airborne/aerosol transmission.

4. In their review, I do not know how they could define a low quality study. They stated that all 67 primary studies are of low quality. However, these studies are published by peer-reviewed journals including those premier ones. If they are of low quality, how they could pass the rigorous screening of these journals? On the other hand, this review did not state which are high quality studies and they did not provide them either. I think they should at least provide high quality data to support their conclusion. It seems they used "low quality data" to produce "high quality" conclusions.

5. For bioaerosol studies, there are no unified or standardized methods or procedures. Different studies have different purposes, different circumstances, different set of sampling tools (the efficiencies could vary greatly; in terms of sampling biological agents higher physical efficiency usually results in higher damage). So, different sampling tools have very different efficiencies. Because viral level is greatly diluted in the air, higher volume or longer sampling time is required to enrich enough viral particles for detection. Most of the studies they complied used RT-PCR for quantification. Depending on the detection kit used, the efficiencies could also vary greatly. Generally, the detection limits of RT-PCR are higher, and accordingly those samples with low viral level would be tested negative. If a more sensitive method such as digital PCR (1 copy per uL) was used, higher percentage of positive samples would be reported.

6. Clearly the review did not discuss how any ventilation would affect the airborne viral levels. Air is constantly moving in not enclosed environments. Thus, air sampling is very time sensitive. Besides, emission of viral particles by the patients might not be continuous. Airborne detection of SARS-CoV-2 is highly time dependent in ventilated environments. 
7. For airborne transmission, increasing physical distance significantly reduces the viral levels depending on the indoor building ceiling height and ventilation status. Human inhalation of the airborne virus is a comparably gentle sampling (causing less damage), and the respiratory tract provides a better incubation environment for SARS-CoV-2. Thus, mechanical air sampling together with in vitro viability tests cannot confirm the true non-infectiveness of airborne SARS-CoV-2 given the results are negative. In addition to shared space, shared time in an indoor space might be also important for airborne transmission to occur. Shared time would allow the virus not to age for too long in the air before inhaled. All of this should be discussed in the review.

8. The tables take up most of the review, however high quality discussion is lacking. It is often observed that the statements in the review lack references.

\section{Minor comments}

1. Technical presentation of the data are not good. To me, all the tables prepared are like a laundry list of items without in-depth discussion or elaboration. Often, some important information present in certain studies they cited are not included in the table or in the discussion. For example, Ma et al. (2020) $)^{1}$ found COVID-19 patients emit millions of SARS-CoV-2 during just breathing, implying great potential of aerosol transmission of the diseases. Breathing produces fine aerosol particles. However, they did not elaborate on this. Nonetheless, viable SARS-CoV-2 was indeed recovered from hospital air. But, the review did not provide direct data against the airborne transmission.

2. There are many grammar mistakes throughout the manuscript as pointed out by other reviewers.

3. The debate or discrepancy might primarily arise from different understanding and definition of aerosol, droplet or airborne transmission from different communities. Aerosol concentration is higher in close ranges, while it is substantially diluted with increasing physical distance, like injecting a drop of ink into a sea. The dose and viability of the virus also play important roles in terms of causing an infection. This should be discussed in a more neutral tone in the review.

I strongly encourage the authors to include aerosol scientists to provide a comprehensive and correct guidance/review that the WHO can use to save millions of lives. Time and resources for certain regions are running out $\&$ actions need to be taken immediately.

\section{I have provided some references for the authors to further read the details of relevant topics I have discussed in the report:}

Greenhalgh, Trisha, Jose L. Jimenez, Kimberly A. Prather, Zeynep Tufekci, David Fisman, and Robert Schooley. Ten scientific reasons in support of airborne transmission of SARS-CoV-2. The Lancet 397, no. 10285 (2021): 1603-1605.

Morawska, Lidia, Julian W. Tang, William Bahnfleth, Philomena M. Bluyssen, Atze Boerstra, Giorgio Buonanno, Junji Cao et al. How can airborne transmission of COVID-19 indoors be minimised?. Environment international 142 (2020): 105832. 
Yao, Maosheng, Lu Zhang, Jianxin Ma, and Lian Zhou. On airborne transmission and control of SARS-Cov-2. Science of The Total Environment 731 (2020): 139178.

Wilson, Nick, Stephen Corbett, and Euan Tovey. Airborne transmission of covid-19. BMJ 370 (2020).

Morawska, Lidia, and Donald K. Milton. It is time to address airborne transmission of coronavirus disease 2019 (COVID-19). Clinical Infectious Diseases 71, no. 9 (2020): 2311-2313.

Prather, Kimberly A., Linsey C. Marr, Robert T. Schooley, Melissa A. McDiarmid, Mary E. Wilson, and Donald K. Milton. Airborne transmission of SARS-CoV-2. Science 370, no. 6514 (2020): 303-304.

\section{References}

1. Ma J, Qi X, Chen H, Li X, et al.: COVID-19 patients in earlier stages exhaled millions of SARS-CoV-2 per hour.Clin Infect Dis. 2020. PubMed Abstract | Publisher Full Text

Are the rationale for, and objectives of, the Systematic Review clearly stated? No

Are sufficient details of the methods and analysis provided to allow replication by others? No

Is the statistical analysis and its interpretation appropriate?

Partly

Are the conclusions drawn adequately supported by the results presented in the review? No

Competing Interests: No competing interests were disclosed.

Reviewer Expertise: I obtained a PhD in conducting bioaerosol related studies from Rutgers University; and did postdoc training at Yale in the same field. I am currently a Professor from Peking University, and has been working in bioaerosol field for about 20 years. My expertise ranges from bioaerosol sampling and detection to air pollution health effects and particulate matter toxicity.

I confirm that I have read this submission and believe that I have an appropriate level of expertise to state that I do not consider it to be of an acceptable scientific standard, for reasons outlined above.

Author Response 25 Aug 2021

Carl Carl, University of Oxford, Oxford, UK

Peer Reviewer \#3

First, I have to declare that this review is provided solely based on scientific evidence and reasoning without any discipline preferences or conflicting interests. Despite not being 
exhaustive, I have to greatly applaud the efforts of all the authors for developing this review, especially the compiling of relevant COVID-19 aerosol related articles. However, to me this review serves as a perfect piece for evidence compiled for probable airborne transmission of COVID-19 if the biased discussion and preferences of content inclusion are eliminated/avoided. Thus, I feel this review, if to be indexed, needs to completely change the tone, and better suited for an article with a title like: Evidences for probable aerosol transmission of COVID-19: a systematic review. For its current form, there are many problematic issues with this review, and the discussion is also biased.

Revised: Thanks. We have made several revisions to the original submission and we believe the quality of the manuscript is much improved. We do not agree with the reviewer that the title must be changed based on our rigorous review of the evidence presented within the papers we assessed.

Major comments are listed below:

1. This review is commissioned and supported by the WHO (World Health Organization) which has clearly stated in March 2020 that COVID-19 is not airborne. An effort supported by the WHO is hardly believed to use to overturn its own statements or harm its authority. Thus, the authors should provide documents that can demonstrate such potential conflicting interests can be sufficiently cleared. Otherwise, I can only say that this review just serves as a proxy of the WHO for its statements with a biased science provided.

Response: The guidance by the WHO on modes of transmission of SARS-COV-2 is constantly evolving and has done so since March 2020. The reviewer has made assumptions which are simply untrue and inaccurate. Such documents do not exist as WHO had no influence in any of our reviews, the process included for the reviews or the interpretation of the results. This standard of proof is not required by editors for submitted manuscripts ( $\mathrm{CH}$ has been an Editor-in-Chief of a BMJ journal, IJO has been a research editor and JMC has also been an Editor-in-Chief of a Journal). A peer reviewer who has submitted previous research would know the requirements for submission according to the ICMJE criteria. The insinuation of overt bias by this reviewer is unfounded and the statement should be retracted.

2. The aerosol definition was not effectively or properly communicated. For example, in the Introduction, they state that "aerosol particle ranges from $0.001 \mu \mathrm{m}$ to over $100 \mathrm{~mm}$ ". Are they sure that there are $10 \mathrm{~cm}(100 \mathrm{~mm})$ aerosol particles in the air? In case they mistyped the unit, e.g., $100 \mu \mathrm{m}$ should be used. Experimental data in many studies (they did not cite) show that major fraction of exhaled particles during breathing or speaking in controlled and real world scenarios are smaller than $5 \mu \mathrm{m}$, and sometimes they peak at $1 \mu \mathrm{m}$. Most recently, US CDC states that surface contact transmission of COVID-19 is minimal (the authors should certainly update the review). Therefore, how do the authors explain the COVID-19 transmission between people? They might attribute the droplet transmission. But, airborne droplet is an aerosol by definition. The review did not provide any data for droplet transmission. Instead, they have provided a lot of studies that have detected SARS-CoV- 2 in aerosol particles.

Response: We have redefined aerosol (see the response to peer reviewer \#1 above). 
3. This review lacks a significant amount of discussion of aerosol physics (very important) in terms with aerosol transmission of COVID-19. For example, a lot of studies they provided used a filter to sample air, and it is known that filtration itself can cause desiccation which affects the integrity of biological cells/particles over a prolonged time period. Accordingly, it partially attributed to low recovery of viable SARS-CoV-2 virus. For impaction or liquid based studies, the sampling velocity could also damage the integrity of the viruses, e.g., the BioSampler has an impact velocity of up to $300 \mathrm{~m} / \mathrm{s}$ by calculation, which would somehow damage the virus. Besides, when the viruses are released into the air, they would be rapidly diluted and transported away given any ventilation of either natural or mechanical nature is present. Thus, the airborne viral concentration level is time, ventilation, and space dependent. The aging of the virus in the air also affect its viability. In addition, the in vitro viability tests with cells can not be directly translated back to the infection of human cells inside the body where the overall physiological environment is different, and more favorable for viral replication. So far, no studies have demonstrated that those in vitro tested non-infectious viruses cannot infect humans. Human inhalation takes place at a rate of about $12 \mathrm{~L} / \mathrm{min}$, which is relatively gentle in terms of sampling stress on the virus. Therefore, their argument that lack of recovery of viable virus prevents a firm conclusion of airborne transmission of COVID-19 is not supported by their reasoning and existing data. Instead, many outbreaks or infections are difficult to explain without referring to airborne/aerosol transmission.

Response:

We have shown the bewildering array of samplers used in the studies. The reviewer raises a good point, but it is a subject matter beyond the scope of our systematic review and our protocol. We might suggest the reviewer and others in the field could contribute to establish an international standard for air capture and hope that all primary studies conform to that standard which we will be quite happy to report in future reviews.

The review by Verreault and colleagues (Methods for sampling of airborne viruses. Microbiol Mol Biol Rev. 2008;72(3):413-444. doi:10.1128/MMBR.00002-08) sets out some of the basic principles in improving the methods in this area and has been included as a reference in the revised manuscript.

'Many types of samplers have been used over the years, including liquid impingers, solid impactors, filters, electrostatic precipitators, and many others. The efficiencies of these samplers depend on a variety of environmental and methodological factors that can affect the integrity of the virus structure. The aerodynamic size distribution of the aerosol also has a direct effect on sampler efficiency. Viral aerosols can be studied under controlled laboratory conditions, using biological or nonbiological tracers and surrogate viruses, which are also discussed in this review. Lastly, general recommendations are made regarding future studies on the sampling of airborne viruses.'

4. In their review, I do not know how they could define a low quality study. They stated that all 67 primary studies are of low quality. However, these studies are published by peer- 
reviewed journals including those premier ones. If they are of low quality, how they could pass the rigorous screening of these journals? On the other hand, this review did not state which are high quality studies and they did not provide them either. I think they should at least provide high quality data to support their conclusion. It seems they used "low quality data" to produce "high quality" conclusions.

\section{Response: We have expanded the methods section describing how we assessed study quality (see the response to peer reviewer \#1 above).}

5. For bioaerosol studies, there are no unified or standardized methods or procedures. Different studies have different purposes, different circumstances, different set of sampling tools (the efficiencies could vary greatly; in terms of sampling biological agents higher physical efficiency usually results in higher damage). So, different sampling tools have very different efficiencies. Because viral level is greatly diluted in the air, higher volume or longer sampling time is required to enrich enough viral particles for detection. Most of the studies they complied used RT-PCR for quantification. Depending on the detection kit used, the efficiencies could also vary greatly. Generally, the detection limits of RT-PCR are higher, and accordingly those samples with low viral level would be tested negative. If a more sensitive method such as digital PCR (1 copy per uL) was used, higher percentage of positive samples would be reported.

See response to comment 3.

Response: We agree that the methods can be improved and made more sensitive. This should be the focus of future work but is not an area that we are able to address.

6. Clearly the review did not discuss how any ventilation would affect the airborne viral levels. Air is constantly moving in not enclosed environments. Thus, air sampling is very time sensitive. Besides, emission of viral particles by the patients might not be continuous. Airborne detection of SARS-CoV-2 is highly time dependent in ventilated environments.

Response: We agree and ventilation issues were considered to be beyond the scope of work outlined for this systematic review. It would be a very interesting topic for a future systematic review.

7. For airborne transmission, increasing physical distance significantly reduces the viral levels depending on the indoor building ceiling height and ventilation status. Human inhalation of the airborne virus is a comparably gentle sampling (causing less damage), and the respiratory tract provides a better incubation environment for SARS-CoV-2. Thus, mechanical air sampling together with in vitro viability tests cannot confirm the true noninfectiveness of airborne SARS-CoV-2 given the results are negative. In addition to shared space, shared time in an indoor space might be also important for airborne transmission to occur. Shared time would allow the virus not to age for too long in the air before inhaled. All of this should be discussed in the review.

Response: Thanks for the comments. We appreciate the points raised but these mechanistic hypotheses are beyond the scope and intent of our systematic review. A separate review of mechanistic modes of transmission would be of value in the future. 
8. The tables take up most of the review, however high quality discussion is lacking. It is often observed that the statements in the review lack references.

\section{Response: The tables report the evidence, we can comment but it's up to the readers to consider our conclusions.}

\section{Minor comments}

1. Technical presentation of the data are not good. To me, all the tables prepared are like a laundry list of items without in-depth discussion or elaboration. Often, some important information present in certain studies they cited are not included in the table or in the discussion. For example, Ma et al. (2020) ${ }^{1}$ found COVID-19 patients emit millions of SARSCoV-2 during just breathing, implying great potential of aerosol transmission of the diseases. Breathing produces fine aerosol particles. However, they did not elaborate on this. Nonetheless, viable SARS-CoV-2 was indeed recovered from hospital air. But, the review did not provide direct data against the airborne transmission.

\section{Response: We have attempted to lay out the information in the tables in line with previous reviews. We have also revisited the information to ensure the information presented is relevant.}

Ma and colleagues suggested COVID-19 patients recruited in Beijing exhaled millions of SARS-CoV-2 RNA copies into the air per hour and that exhaled breath emission may play an important role in the COVID-19 transmission. The Ct values of the breath and air samples, respectively (35.54 \pm 3.14 and 38.40 ) are extremely high and not compatible with infectious virus based on other studies that have correlated infectious virus and Ct values (Jefferson $T$, Spencer EA, Brassey J, Heneghan C. Viral cultures for COVID-19 infectious potential assessment - a systematic review. Clin Infect Dis. 2020 Dec 3:ciaa1764. doi: 10.1093/cid/ciaa1764. Epub ahead of print. PMID: 33270107; PMCID: PMC779932). The mere presence of RNA copies based on PCR sampling does not imply infectiousness and the reviewer comments suggesting millions of SARS-CoV-2 intact viruses are emitted during breathing and capable of causing infection does not have evidence to support the statement from what we have been able to find.

Response: Meaningful inference can only be drawn from solid evidence.

2. There are many grammar mistakes throughout the manuscript as pointed out by other reviewers.

\section{Response: Thanks. We have checked for grammatical errors and typos.}

3. The debate or discrepancy might primarily arise from different understanding and definition of aerosol, droplet or airborne transmission from different communities. Aerosol concentration is higher in close ranges, while it is substantially diluted with increasing physical distance, like injecting a drop of ink into a sea. The dose and viability of the virus also play important roles in terms of causing an infection. This should be discussed in a 
more neutral tone in the review.

Response: We have already commented on the confusing nature of the definitions of aerosol, droplet and airborne transmission.

I strongly encourage the authors to include aerosol scientists to provide a comprehensive and correct guidance/review that the WHO can use to save millions of lives. Time and resources for certain regions are running out \& actions need to be taken immediately.

Response: We have substantial expertise and experience within our team (see the response to peer reviewer \#2 above.

Of note, in undertaking peer review the ICMJE states: 'Reviewers should declare their relationships and activities that might bias their evaluation of a manuscript and recuse themselves from the peer-review process if a conflict exists.' Intellectual conflicts would introduce such bias to peer review assessments. And according to COPE's Ethical Guidelines for Peer Reviewers, COPE also highlights that the professional responsibility underpinning the peer review requires the necessary expertise to assess the manuscript and can provide an unbiased assessment.

We do not engage in emotive statements regarding the reviewers' opinions. We ensure our comments are evidence-based, unbiased and reflect the best available evidence. The reviewer should note that we do not speak for WHO and two co-authors of this review are currently collaborating with aerosol scientists to look for highquality evidence relating to the mechanism(s) of transmission.

Competing Interests: No competing interests were disclosed.

Reviewer Report 22 April 2021

https://doi.org/10.5256/f1000research.55319.r82064

(c) 2021 Leung N. This is an open access peer review report distributed under the terms of the Creative Commons Attribution License, which permits unrestricted use, distribution, and reproduction in any medium, provided the original work is properly cited.

Nancy H. L. Leung

WHO Collaborating Centre for Infectious Disease Epidemiology and Control, School of Public Health, Li Ka Shing Faculty of Medicine, The University of Hong Kong, Hong Kong, Hong Kong

In this systematic review, Heneghan et al. attempted to summarise the literature on the role of airborne transmission for SARS-CoV-2, with a focus of air sampling studies or epidemiologic studies that may evaluate the aerosol mode of transmission. They described that all primary research studies selected were low quality, probably attributing to the lack of standard methods, sampling sizes and reporting items. They concluded that SARS-CoV-2 was intermittently detected 
in the air, but the lack of recoverable viral culture samples prevents conclusions over airborne transmission.

I applaud the authors' attempt in summarising the current literature. I also agree the results of the selected studies are heterogeneous, and that currently there is very minimal number of studies that demonstrated infectious virus recovered in the air. This review would have been very useful as an evidence base for future discussion on the importance of aerosol transmission; however, the lack of objective and systematic evaluation of the methodology used in the selected studies precludes such usefulness. My major concern is that the review set out with the assumption that "the quality of transmission studies is known to be low" (reference \#9 was also irrelevantly cited as described further below), although one of the main purposes of this review would be to evaluate the quality of evidence of each study. The benchmarks used to evaluate whether "Analysis \& reporting outcomes (are) appropriate" (Table 3) were not described, but which were critical to evaluate the quality of each study. The assumption of air sampling studies were of poor quality in general can be felt along the manuscript, especially in Table 6 with a very large paragraph of criticism on Santarpia 2020, but personally I think a lot of evaluation on this particular study was misguided due to insufficient understanding of the methodology used (as described further below). In some instances, studies were being described as poorly done without explanation of why the authors think so. I think including authors who have working knowledge in the field of air sampling studies and/or epidemiologic transmission studies would help to improve this review greatly.

There are also quite a number of missing information in the Tables, truncated sentences and typos, which requires a thorough re-read and check.

Please also find my specific comments below:

\section{Introduction}

Airborne transmission is defined as the spread of an infectious agent caused by the dissemination of droplet nuclei (aerosols) that remain infectious when suspended in air over long distances and time For this definition of airborne (aerosol) transmission, emerging discussion has suggested aerosol transmission occurs in both short- and long-range (see my review ${ }^{1}$ ).

A collection of particles (liquid or solid) ranging in size from $0.001 \mu \mathrm{m}$ to over $100 \mathrm{~mm}$ suspended in a gas defines an aerosol.

This is the classic definition of aerosols from the discipline of occupational hygiene, but other disciplines with a specific focus on bioaerosols with the origin of infectious pathogens

\section{Method} may differ based on different aspects of transmission ${ }^{1}$.

Studies can be observational including case series, ecological, or prospective; or interventional including randomised trials and clinical reports, outbreak reports, case-control studies, experimental studies, nonpredictive modelling. Studies should include sampling for the detection of SARs-CoV-2. Studies on factors influencing transmission are included, such as location settings, meteorological or immunological factors. Studies incorporating models to describe observed data were eligible. Studies reporting solely predictive modelling were excluded.

These classification of study design are ambiguous; for example, what was the intervention being studied in interventional studies? Shouldn't clinical reports, outbreak reports and case-control studies be classified as observational studies? Were retrospective observational studies included, and on the other hand randomised trials would always be prospective? 
Overall, if these study designs are merely summaries of studies identified from systematic search based on well-defined search terms and are not being used for inclusion/ exclusion of studies, I would suggest to move these descriptions to the Results section instead, and only keep those that are relevant to study selection in the Method section (e.g. "Studies should include sampling for the detection of SARs-CoV-2.")

Studies should include sampling for the detection of SARs-CoV-2.

Do you mean "air sampling for the detection of SARS-CoV-2"?

We also extracted data on the type of study, setting, sample source and methods, RT-PCR positive samples for SARS-CoV-2 RNA including cycle threshold (Ct) and copies per m3, viral culture methods and results, size of air particles (when reported) and proportion in the sample.

For "copies per m3", do you mean "copies per m3 air sampled"? For "proportion in the sample", what is the numerator and the denominator - e.g., NIOSH sampler is commonly used in air sampling study, and for each time of collection the same volume of air are segregated into 3 size-fractions, would this be counted as 1 or 3 air samples? Alternatively, some studies will use multiple samplers in the same collection (e.g. being placed at different locations in the patient room), would this be considered as multiple samples or one sample (run)? A clear definition is needed to allow comparison between studies, and should also be clearly described in Table 1.

We assessed quality using a modified QUADAS 2 risk of bias tool, ${ }^{8}$. We simplified the tool as the included studies were not designed as primary diagnostic accuracy studies and the quality of transmission studies is known to be low? .

As listed in Table 3, one of the criteria was "Analysis \& reporting outcomes appropriate". What were the benchmarks that were being used to be evaluated against about whether the analysis or the reporting outcomes are appropriate or not?

The use of reference \#9 here is inappropriate as it refers to transmission during the symptomatic or asymptomatic phase, with no mention of any modes of transmission. Truncated sentence ("after tool,").

\section{Results}

Limitations of the sampling methods and the poor-quality reporting make it difficult to discriminate between airborne or droplet nuclei transmission.

Is "airborne" a typo here?

We included 67 primary studies, of which 53 (79\%) reported binary data on RT-PCR air samples (see Table 1). All were descriptive observational and none were comparative.

Comparative refers to comparison between what?

Overall the reporting was heterogeneous.

Do you mean the methods or the results in the reported studies were heterogeneous?

Hospital. There were 50 studies conducted in healthcare settings: 45 studies included binary RT-PCR air samples (42 hospitals, 2 outdoors and 1 student healthcare centre).

Should "outdoors" be considered as healthcare settings? Similarly in the paragraphs follow about outdoors and community, actually I would think the distinction lies in outdoors vs. indoors, and within indoor higher-risk (e.g. healthcare settings/ households with confirmed cases) vs lower-risk (restaurants/ public transport etc)

(142 positives out of 1,403 samples: average 10.1\%).

Please refer to my above comments on the numerator/ denominator for the proportion of samples - can the proportions from different studies (which may refer to different things) be combined? What does this $10.1 \%$ represent/ how to interpret?

Three studies reported on two choir practices and potential air transmission. Charlotte $N$ et al. followed- 
up a choir practice in France with 27 participants who attended a choir practice on 12 March 2020. Two separate publications [Hamner L 2020 and Miller SL 2020] published on the same Choir Practice Skagit County, Washington, USA. In total, 78 members attended two practices: $87 \%$ of choir members subsequently became ill (32 confirmed cases and 20 probable secondary cases).

I suggest to move this paragraph to a new section, as these evidence refers to whether a transmission event has occurred (i.e. whether someone is infected), which is a different outcome measure from recovering virus in the air.

\section{Discussion}

Some of the reasons for this may be methodological weaknesses in the study design, the lack of validated methods and the location and variable distance of the sampling.

- Please elaborate what (1) the weaknesses and (2) the lack of validated methods are referring to

Past attempts to detect infectious particles have proved difficult: aerosols are dilute and culturing fine particles is problematic.

Why is culturing fine particles (as opposed to coarse particles?) problematic, apart from being diluted?

In a NEJM editorial, Roy et al., report 'the only clear proof that any communicable disease is transmitted by aerosol came from the famous experiment by Wells, Riley, and Mills in the 1950s, which required years of continual exposure of a large colony of guinea pigs to a clinical ward filled with patients who had active tuberculosis11.'

There was clear evidence in terms of observed transmission event via the aerosol route for measles, chickenpox and rhinovirus ${ }^{1}$.

For coronaviruses, previous evidence supporting the airborne route of transmission is weak ${ }^{13}$. Please clarify that this review was published before the COVID-19 pandemic.

There is a current lack of well-conducted studies addressing airborne transmission: only nine studies identified during the search period reported air sampling outdoors and, in the environment, outside of hospitals.

How do air sampling studies conducted outdoors (as opposed to indoors), or the lack thereof, suggest the studies are not well-conducted - should the studies be evaluated based on methodological robustness instead (e.g. sampling duration, attempt to recover infectious virus, etc.)?

Transmission evidence should be context specific to particular settings (i.e., indoor or outdoor), environment- specific (i.e., the presence of UV light. ventilation etc.) and ensure that exposure an infectious agent has taken place.

exposure to an infectious agent?

No airborne study to date definitively demonstrates SARS-CoV-2 is of an infectious nature, which offers the most robust evidence of transmissibility ${ }^{22}$.

Do you mean "SARS-CoV-2_recovered in the air_"? Do you mean "evidence of aerosol transmission" instead of "transmissibility" (please note the difference between "transmissibility" and "modes of transmission" ${ }^{11}$ )? I'm not sure whether identifying infectious virus in the air is the most robust evidence of aerosol route, as whether aerosol transmission can take place also depends on the susceptibility of the infected person to the aerosol route, and I would think a demonstration of transmission event takes place via the aerosol route would be a stronger evidence.

\section{Table 1}

Binder 2020: which decreases tlo approximately 40\% efficiency for aerosols $\sim 80 \mu \mathrm{m}$ in diameter --> typo. 
Charlotte N 2020: please describe the lack of ventilation as described in Charlotte et al.

Horve PF 2020: 14/56 s ---> typo.

Li \& Qian 2020: missing notes.

Lu J 2020: please describe the study scenarios/ findings that were relevant to why the study was selected (e.g. airflow consistent with transmission).

Mponponsuo 2020: why was this study selected? the type of high-risk behaviour/ procedure has not been described in the study?

Bahl P 2020: please be aware of plagiarism and rephrase.

Ji B 2020: Missing main results.

Singhai S 2020: Missing main results and key conclusions.

Hussain A 2020: Missing key conclusions.

Correia G 2020: Missing main results.

\section{Figure 1}

Full-text articles excluded because no transmission outcome studied ---> What does 'transmission outcome' refer to here? From my understanding, 'transmission outcome' refers to whether an infection is initiated in an exposed person; but most of the air sampling studies included in this review did not demonstrate such 'transmission outcome'

\section{Figure 2}

For "Was follow up sufficient", referring to Table 2, shouldn't the $83.6 \%$ mostly be "Not Applicable" instead of "No/Unclear"?

\section{Table 4}

please check to see the use of unit symbol is consistent in the Table (uM vs. um; copies/L vs. $/ L$, copies $/ \mathrm{m}^{3}$ vs. copies $\mathrm{m}^{3}, \mathrm{~m}^{2}$ vs. $\mathrm{m}^{3}, \mathrm{~m}^{3}$ vs. $\mathrm{m} 3$ ).

Chirizz D 2020: please kindly indicate which size ranges were reported.

Horve PF 2020: truncated sentence.

Liu Y \& Ning Z 2020: typo ("rang-").

Zhou J 2020: 101 copies per how much air?

\section{Table 5}

Feng B 2020: truncated sentence.

\section{Figure 4}

Table 6

Similar to my comments about numerator/ denominator above, were the proportions reported between studies directly comparable?

Binder 2020: a Ct of <20 would be considered as high viral load that may be sufficient to be culturable?

$\mathrm{Hu}$ J: missing publication year.

Lednicky 2020a:

it is not clear why plaque assays could not be performed due to a nationwide non-availability of some critical media components in the US. ---> I think Lednicky et al. meant that due to lack of components which make up the culture media (for cultivating the cells to be infected), plaque assay (which involves the use of cells to be infected) cannot be performed.

Santarpia JL 2020a:

For Santapria 2020 (a) we could only find a preprint publication. ---> it is now published in Scientific Reports. 
Increased viral RNA presence is a surrogate and subject to many interpretations and should not be considered equal to the cultivation of replication and infection competent virus on cell culture which was not identified. ---> Please elaborate on this statement - how to explain the increased viral RNA presence if it is not because of viral replication?

Western blot assay was not done in cell supernatant samples with non-statistically significant evidence of replication, which would have acted as a control to ensure the findings were not spurious. Western blots are very weak, with no positive control or size markers and the signal doesn't necessarily come from a replicating virus, there's no "before culture" analysis. ---> In contrast to this statement, referring to Figure 2 in Santarpia JL 2020a, mock (negative control) samples have already been included. Anti-SARS nucleocapsid protein (SARS-CoV N) antibody were used in Western blot which is specific to SARS-CoV-2 virions. A significant test has been done for viral load between day 1 vs. day 5/6, and significant increase in viral load would be suggestive of viral replication between these days.

No size-fractionation techniques were used to determine the size range of SARS-CoV-2 droplets and particles, raising major issues with the statement the data suggests that viral aerosol particles are produced by individuals that have the COVID-19. ---> The NIOSH samplers (commonly used in air sampling studies) were used in this study, which size-fractionated the sampled air.

No plaques were reported to have been detected and no serial passage on subculture was reported. ---> Plaque assay nor serial passage was attempted in the study.

Statistical inferences are very difficult to interpret in Figure 1 based on the error bars. ---> Student's t test was done to compare viral load between day 1 vs. day 5/6.

The broad sweeping conclusions that SARS-COV-2 RNA exists in respired aerosols less than $5 \mu \mathrm{m}$ in diameter; that aerosols containing SARS-CoV-2 RNA exist in particle modes that are produced during respiration is difficult to justify based on the findings presented. ---> Refers to above comment on the use of NIOSH samplers in this study.

It is likely an equation as used to calculate the concentration of the virus, however, it is more robust to measure the virus directly than use an equation. ---> Virus in the sample was being measured directly to obtain Ct values, which was then translated to viral load based on standard curve (i. e. a serial dilution of virus of different concentration) from a known quantity of SARS-CoV-2 virus.

EM also does not confirm live virus and does not indicate active viral replication as the authors suggest - where are the comparisons control EM photomicrographs. ---> The significant Table 7 increase in viral RNA from day 1 to day 5/6 would be suggestive of viral replication.

Santarpia JL 2020b: Partial evidence of virus replication from one air sample. ---> typo.

\section{References}

1. Leung NHL: Transmissibility and transmission of respiratory viruses. Nat Rev Microbiol. 2021. 


\section{PubMed Abstract | Publisher Full Text}

Are the rationale for, and objectives of, the Systematic Review clearly stated? Yes

Are sufficient details of the methods and analysis provided to allow replication by others? Partly

Is the statistical analysis and its interpretation appropriate?

Not applicable

Are the conclusions drawn adequately supported by the results presented in the review? Partly

Competing Interests: No competing interests were disclosed.

Reviewer Expertise: Infectious disease epidemiology; aerosol transmission; modes of transmission; respiratory viruses; air sampling studies; field studies

I confirm that I have read this submission and believe that I have an appropriate level of expertise to confirm that it is of an acceptable scientific standard, however I have significant reservations, as outlined above.

Author Response 25 Aug 2021

Carl Carl, University of Oxford, UK

Peer reviewer 2

1. In this systematic review, Heneghan et al. attempted to summarise the literature on the role of airborne transmission for SARS-CoV-2, with a focus of air sampling studies or epidemiologic studies that may evaluate the aerosol mode of transmission. They described that all primary research studies selected were low quality, probably attributing to the lack of standard methods, sampling sizes and reporting items. They concluded that SARS-CoV-2 was intermittently detected in the air, but the lack of recoverable viral culture samples prevents conclusions over airborne transmission.

Response:

Thank you. Our team includes an expert virologist, a vaccinologist and an infectious disease specialist and epidemiologists. We have expanded our methods section to show how we assessed the quality of included studies (see response above).

2. I applaud the authors' attempt in summarising the current literature. I also agree the results of the selected studies are heterogeneous, and that currently there is very minimal number of studies that demonstrated infectious virus recovered in the air. This review would have been very useful as an evidence base for future discussion on the importance of aerosol transmission; however, the lack of objective and systematic evaluation of the 
methodology used in the selected studies precludes such usefulness. My major concern is that the review set out with the assumption that "the quality of transmission studies is known to be low" (reference \#9 was also irrelevantly cited as described further below), although one of the main purposes of this review would be to evaluate the quality of evidence of each study. The benchmarks used to evaluate whether "Analysis \& reporting outcomes (are) appropriate" (Table 3) were not described, but which were critical to evaluate the quality of each study. The assumption of air sampling studies were of poor quality in general can be felt along the manuscript, especially in Table 6 with a very large paragraph of criticism on Santarpia 2020, but personally I think a lot of evaluation on this particular study was misguided due to insufficient understanding of the methodology used (as described further below). In some instances, studies were being described as poorly done without explanation of why the authors think so. I think including authors who have working knowledge in the field of air sampling studies and/or epidemiologic transmission studies would help to improve this review greatly.

Response:

Thanks for your observations. We have made some revisions.

We have revised the statement regarding reference \#9.

"We simplified the tool because the included studies were not designed as primary diagnostic accuracy studies, and there is a lack of high-quality data in published transmission studies"

We have expanded the process used to assess the reporting quality in the methods section.

Our team includes viral transmission experts, epidemiologists, clinicians and systematic review experts. This review set out to assess whether published studies demonstrated evidence of SARS-CoV-2 transmissibility.

The included studies where the culture of viable virus was attempted were analysed in-depth given their importance and the potential for bias. We have considerable expertise in transmission studies. Across nine reviews we have assessed over $\mathbf{5 0 0}$ studies to date. $\mathrm{CH}$ and $\mathrm{TJ}$ are contact editors in the Cochrane Acute Respiratory Group and as a group, we have over 3 decades of experience in systematic reviews and infections. We, therefore, dispute this reviewer's assertion. We have clarified the methods as per the previous reviewer's response.

3. There are also quite a number of missing information in the Tables, truncated sentences and typos, which requires a thorough re-read and check.

Response:

We have re-read the manuscript to check for any grammatical errors and typos.

4. Introduction

Airborne transmission is defined as the spread of an infectious agent caused by the dissemination of droplet nuclei (aerosols) that remain infectious when suspended in air over long distances and 
time

For this definition of airborne (aerosol) transmission, emerging discussion has suggested aerosol transmission occurs in both short- and long-range (see my review).

\section{Response:}

Our definition was based on current WHO guidance. However, we have added a statement to reflect this view:

"Airborne transmission is defined as the spread of an infectious agent caused by the dissemination of droplet nuclei (aerosols) that remain infectious when suspended in air over long distances and time. ${ }^{1}$ However, some authors have defined aerosol transmission as occurring over both short and long distances ( https://www.ncbi.nlm.nih.gov/pmc/articles/PMC7982882/)."

5. A collection of particles (liquid or solid) ranging in size from $0.001 \mu \mathrm{m}$ to over $100 \mathrm{~mm}$ suspended in a gas defines an aerosol.

Response:

We have revised our definition of aerosol (see response to peer reviewer 1 above).

6. Method

Studies can be observational including case series, ecological, or prospective; or interventional including randomised trials and clinical reports, outbreak reports, case-control studies, experimental studies, non-predictive modelling. Studies should include sampling for the detection of SARs-CoV-2. Studies on factors influencing transmission are included, such as location settings, meteorological or immunological factors. Studies incorporating models to describe observed data were eligible. Studies reporting solely predictive modelling were excluded.

\section{Response:}

We have revised the paragraph.

"We primarily included studies that reported sampling for the detection of SARS-CoV-2. However, we also included observational and randomised studies that investigated airborne transmission of SARS-CoV-2." Non-predictive and experimental studies were also considered for inclusion."

7. Studies should include sampling for the detection of SARs-CoV-2.

Do you mean "air sampling for the detection of SARS-CoV-2"?

Response:

Thank you. Revised.

"air sampling for the detection of SARS-CoV-2"

8. We also extracted data on the type of study, setting, sample source and methods, RT-PCR positive samples for SARS-CoV-2 RNA including cycle threshold (Ct) and copies per m3, viral culture methods and results, size of air particles (when reported) and proportion in the sample. 
Response:

Revised to "copies per $\mathbf{m}^{3}$ of sampled air".

The included studies reported the total number of air samples as well as proportion of positive samples (if any). We presented the results as reported by the authors.

We have added the following footnote to table 1:

"For positive air sample proportions, the denominator refers to the total number of air samples as reported by the study authors irrespective of the method used for sampling."

9. Results

Limitations of the sampling methods and the poor-quality reporting make it difficult to discriminate between airborne or droplet nuclei transmission.

Is "airborne" a typo here?

Response:

Thanks. Revised.

"The variation in sample methods coupled with flaws in the reporting make it difficult to distinguish between aerosol and droplet nuclei transmission."

10. We included 67 primary studies, of which 53 (79\%) reported binary data on RT-PCR air samples (see Table 1). All were descriptive observational and none were comparative.

Response: Revised. Deleted "and none were comparative".

\section{"All the studies were observational."}

11. Overall the reporting was heterogeneous.

Do you mean the methods or the results in the reported studies were heterogeneous?

Response:

Thanks. We have revised the sentence. "Overall, there was heterogeneity in the methods used for air sampling across the studies."

12. Hospital. There were 50 studies conducted in healthcare settings: 45 studies included binary RT-PCR air samples (42 hospitals, 2 outdoors and 1 student healthcare centre).

Response:

The outdoors here refers to hospital outdoor environments. We have revised the statements.

"Hospital. There were 50 studies conducted in healthcare settings: $\mathbf{4 5}$ studies included binary RT-PCR air samples: $\mathbf{4 2}$ hospitals, 1 hospital outdoor environment, 1 hospital indoor and outdoor environment and 1 student healthcare centre)." (revise figure 1). 
"Of the studies conducted in the community, 15 were conducted in indoor settings: choir practice (2), care home (1), inside a bus (3), quarantine households (1), meat processing plant (1), block of flats (2), restaurant (3), buses and subway trains (1), and home residence (1); three studies were conducted in outdoor settings: public places (1), industrial outdoor (1) and outdoor of a working/residential area (1)."

13. (142 positives out of 1,403 samples: average 10.1\%).

Response:

We have described the denominator above (total number of air samples irrespective of sampling method).

14. Three studies reported on two choir practices and potential air transmission. Charlotte $N$ et al. followed-up a choir practice in France with 27 participants who attended a choir practice on 12 March 2020. Two separate publications [Hamner L 2020 and Miller SL 2020] published on the same Choir Practice Skagit County, Washington, USA. In total, 78 members attended two practices: $87 \%$ of choir members subsequently became ill (32 confirmed cases and 20 probable secondary cases).

Response:

Revised. Added a new sub-title.

"Indoors."

15. Discussion

Some of the reasons for this may be methodological weaknesses in the study design, the lack of validated methods and the location and variable distance of the sampling.

Response: We have emphasized the need for a framework to assess studies of transmissibility and included a reference.

16. Past attempts to detect infectious particles have proved difficult: aerosols are dilute and culturing fine particles is problematic.

Why is culturing fine particles (as opposed to coarse particles?) problematic, apart from being diluted?

Response: Thank you for raising this point. We have several references below which address this point. The reference by Verreault is one of the most comprehensive on this subject.

Verreault D, Moineau S, Duchaine C. Methods for sampling of airborne viruses.

Microbiol Mol Biol Rev. 2008;72(3):413-444. doi:10.1128/MMBR.00002-08

Aaron J. Prussin, II, Linsey C. Marr, Kyle J. Bibby, Challenges of studying viral aerosol metagenomics and communities in comparison with bacterial and fungal aerosols, FEMS Microbiology Letters, Volume 357, Issue 1, August 2014, Pages 1-9,

see also Lednicky

Viable SARS-CoV-2 in the air of a hospital room with COVID-19 patients 
https://www.ijidonline.com/article/S1201-9712(20)30739-6/fulltext\#.

'The amount of airborne virus detected per liter of air was small, and future studies should address (a) whether this is typical for COVID-19, (b) if this represented virus production relative to the phase of infection in the patient, (c) if this was a consequence of active air flow related to air exchanges within the room, (d) or if the low number of virus was due to technical difficulties in removing small airborne particles from the air.'

See also Collection, particle sizing and detection of airborne viruses

Pan A, Lednicky JA, Wu C.-Y. International Journal of Infectious Diseases. 100 (2020) 476-482

We have referenced Verreault $D$ and Pan $M$ as new references.

17. In a NEJM editorial, Roy et al., report 'the only clear proof that any communicable disease is transmitted by aerosol came from the famous experiment by Wells, Riley, and Mills in the 1950s, which required years of continual exposure of a large colony of guinea pigs to a clinical ward filled with patients who had active tuberculosis.'

Response: We quote what Roy et al. reported in the New England Journal of Medicine who also states there is a "need for a better understanding of aerosol-acquired disease.'

18 For coronaviruses, previous evidence supporting the airborne route of transmission is weak ${ }^{13}$. Please clarify that this review was published before the COVID-19 pandemic.

Response: Clarified: "For coronaviruses, previous review evidence supporting the airborne route of transmission is weak ${ }^{13}$; however, it should be noted that this review was published before the COVID-19 pandemic."

19. There is a current lack of well-conducted studies addressing airborne transmission: only nine studies identified during the search period reported air sampling outdoors and, in the environment, outside of hospitals.

Response: We have deleted this statement within the manuscript.

20. Transmission evidence should be context specific to particular settings (i.e., indoor or outdoor), environment- specific (i.e., the presence of UV light. ventilation etc.) and ensure that exposure an infectious agent has taken place.

Response: Revised: "... ensure that there is evidence of exposure to a transmissible agent"

21. No airborne study to date definitively demonstrates SARS-COV-2 is of an infectious nature, which offers the most robust evidence of transmissibility ${ }^{22}$.

Response: We have revised the statement. "None of the included studies definitively demonstrated that SARS-CoV-2 can be recovered in the air." 
22.

Table 1

Response: Thank you for pointing out the typographical errors and missing notes. We have made revisions to Table 1

$\geq 80 \mu \mathrm{m}$ in diameter

The choir rehearsal room was not ventilated.

14 out of 56 samples

Analysed outbreak using computer models and experiments based on airflow dynamics

Air-conditioned, 5-floor building without windows

It satisfied our inclusion criteria - observational studies of RCT that investigated airborne transmission

Revised; used quotation marks where necessary

Results added

Added

Added

Added

\section{Figure 1}

Response: For instance, several modelling studies did not 'study' a transmission outcome and were therefore excluded. This is different to whether studies 'demonstrate' an effect or not as both would be included irrespective of the result. Otherwise, we would introduce publication bias.

\section{Figure 2}

Response:

We have revised what we mean by follow-up. See methods section.

\section{Table 4}

Response:

Thanks. Revised. We have presented the units as reported by the study authors $(D<0.056 \mu \mathrm{m}$ ) up to coarse particles ( $>18 \mu \mathrm{m}$ ); as reported by the study authors No truncation. Sentence extends into next page

Corrected

Corrected

27. Table 5

Response:

No truncation; statement extends into the next page. 
28. Figure 4

Response:

We have addressed this comment earlier.

29. Table 6

Response:

"A Ct of $<20$ would be considered positive..."

Corrected: Hu J 2020

30 Lednicky 2020a:

Response:

Revised: "The authors reported that plaque assays could not be performed due nonavailability of the components which make up the culture media in the USA."

31. Santarpia JL 2020a:

Response: As far as we are aware, Santarpia 2020(a) is still only available as a preprint. The Scientific Reports citation is the journal publication for Santarpia 2020(b)

See the following reference. The reported changes in RNA were very small and may not be truly reflective of active replicating virus.

Jefferson T, Spencer EA, Brassey J, Heneghan C. Viral cultures for COVID-19 infectious potential assessment - a systematic review [published online ahead of print, 2020 Dec 3]. Clin Infect Dis. 2020;ciaa1764. doi:10.1093/cid/ciaa1764

'Complete live viruses are necessary for transmission, not the fragments identified by PCR. Prospective routine testing of reference and culture specimens and their relationship to symptoms, signs and patient co-factors should be used to define the reliability of PCR for assessing infectious potential. Those with a high cycle threshold are unlikely to have infectious potential.'

Thanks. We have deleted the statement changed text to:

"Neither plaque assay nor serial passage was attempted in the study."

Competing Interests: No competing interests were disclosed. 
(c) 2021 Tomlinson D. This is an open access peer review report distributed under the terms of the Creative Commons Attribution License, which permits unrestricted use, distribution, and reproduction in any medium, provided the original work is properly cited.

\section{David R. Tomlinson}

University Hospitals Plymouth NHS Trust, Plymouth, UK

Dear Professor Heneghan and team,

I would firstly like to congratulate you for publishing this systematic review on an open access site and for inviting comments. I am grateful for being given the opportunity to respond and to provide peer review. I hope you will consider the points I raise to be in the spirit of the best principles of scientific discourse - i.e., having a focus on methodology and without bias. I also hope that you and your team are open to performing major revisions to your manuscript, after consideration of all comments I provide below, and the other forms of feedback received through open access disclosure of this manuscript. Thank you.

1. Page 4: 'A collection of particles (liquid or solid) ranging in size from $0.001 \mu \mathrm{m}$ to over $100 \mathrm{~mm}$ suspended in a gas defines an aerosol.'

You have made a typographical error here (easily done!), since aerosols - 'suspensions in air (or a gas) of solid or liquid particles small enough that they will remain airborne for a prolonged period of time because of their low settling velocity' (Tellier R, 2009¹) - are typically stated as being $<100 \mu \mathrm{m}$ diameter, not $\mathrm{mm}$. In addition, the definition of an aerosol typically includes reference to the time over which such particles may remain suspended in the air: would you consider adding this to the definition used in this present manuscript, please? For example, your methods document uses this wording, which is rather more complete in this respect: 'Respiratory droplets $<5$ $\mu m$ in diameter are referred to as droplet nuclei or aerosols. Airborne transmission is the spread of an infectious agent caused by the dissemination of aerosols that remain infectious when suspended in air over long distances and time.' Thank you.

2. Paragraph 2 of your introduction contains two sentences with $55 \%$ match to the abstract of Kutter et al. (2018) - your reference 4.

This is evidence of presumably accidental plagiarism. The wording should be modified to remedy this please. Thank you.

3. Appendix 7 outlines chosen methodology for excluding studies. Phrases including words such as 'adequately', 'sufficient' and 'clearly defined' are used yet without objective definition provided, introducing the possibility of selection bias.

I would be grateful if you could provide such methodological points in objectively definable terms, please, thereby permitting a more appropriate description as to why each of these studies was ineligible for inclusion. Thank you.

4. Thank you for providing a link to the 'Protocol for a living evidence review (Version 3: 1 December 2020)'. Under 'Study inclusion and exclusion' is stated: 'Eligible studies should include 
sampling for the detection of SARs-CoV-2 in the population or the environment on any potential mode of transmission, including droplet, airborne, fomite, orofecal, bloodborne, vertical or other. Studies can be observational including case series, ecological, or prospective; or interventional including randomised trials and clinical reports, outbreak reports, case-control studies, experimental studies, non-predictive modelling. Studies should include sampling for the detection of SARs-CoV-2.'

Given this description of your intended methods, I am surprised that the methods for the present manuscript state: 'We included field studies that included airborne sampling for SARs-CoV-2 in the population or the environment. Tronically, table 3 of Kutter et al. (your ref 4 ) is highly relevant to this important methodological point, since these authors describe the pros and cons of various methods to determine respiratory virus transmission. The cons of air sampling are noted: technical difficulty and possibly only circumstantial level evidence. However, these authors provide a list of further methods usefully employed including virus stability, outbreak (household or hospital) reports, aircraft outbreaks, non-pharmaceutical intervention, experimental infection, air tracer studies and computational modelling / simulation. Each method has its pros and cons, but it is my contention that restricting your present analyses to studies which included airborne sampling' excludes a large body of data which has been the foundation of investigations towards establishing routes of transmission of respiratory viruses amongst humans. Indeed, if your present methods were applied to measles, one would have to conclude that measles is not transmitted via the airborne route since live virus has never been successfully cultured from air samples. Therefore, and in line with this accepted and referenced practice within the field of infectious diseases, it is my contention that your present manuscript should include data from all suitably rigorous* experimental resources and outbreak reports listed here and as described by Kutter et al. Thank you.

[*Please forgive my use of a subjective term here: wording would be usefully informed by your response to point (3) I raise, above.]

In case this suggestion seems rather 'obtuse', I would like to draw upon two examples of excluding studies purely on the basis of their laboratory setting and the impact this may have on the validity of any such transmission review.

Firstly, the experiments of van Doremalen et al. (2020) ${ }^{2}$, in my opinion, represent a particularly valuable contribution towards understanding the possibility of airborne transmission of SARS-CoV2.

\section{Van Doremalen outline methods:}

'Virus stability in aerosols was determined as described previously at $65 \%$ relative humidity (RH) and 21 $23^{\circ} \mathrm{C}$ (Fischer et al., 2016). In short, aerosols $(<5 \mu \mathrm{m})$ containing HCoV-19 $(105.25 \mathrm{TCID} 50 / \mathrm{mL})$ or SARSCoV-1 (106.75-7 TCID50/mL) were generated using a 3-jet Collison nebulizer and fed into a Goldberg drum to create an aerosolized environment. Aerosols were maintained in the Goldberg drum and samples were collected at 0,30,60, 120 and 180 minutes post-aerosolization on a $47 \mathrm{~mm}$ gelatin filter (Sartorius). Filters were dissolved in $10 \mathrm{~mL}$ of DMEM containing $10 \% \mathrm{FBS}$. Three replicate experiments were performed.'

'Viable virus in all surface and aerosol samples was quantified by end-point titration on Vero E6 cells as described previously (van Doremalen et al., 2013).'

\section{Results (extract):}


'SARS-CoV-2 remained viable in aerosols throughout the duration of our experiment (3 hours), with a reduction in infectious titer from $10^{3.5}$ to $10^{2.7}$ TCID $_{50}$ per liter of air. This reduction was similar to that observed with SARS-CoV-1, from $10^{4.3}$ to $10^{3.5}$ TCID $_{50}$ per milliliter.'

\section{Conclusions (extract):}

'Our results indicate that aerosol and fomite transmission of SARS-COV-2 is plausible, since the virus can remain viable and infectious in aerosols for hours and on surfaces up to days (depending on the inoculum shed). These findings echo those with SARS-CoV-1, in which these forms of transmission were associated with nosocomial spread and super-spreading events, and they provide information for pandemic mitigation efforts.'

That this study was excluded from your review on the basis of its laboratory setting can only imply that you believe different physical laws might be in operation in a Goldberg drum compared to 'normal air'. However, it is clearly inconceivable that the air within a Goldberg drum using the methods described has unique virus lifespan-enhancing properties. Furthermore, it is biologically implausible that SARS-CoV-2 only ever achieves aerosol viability when these same aerosols are created using a Collison nebuliser. Indeed, if the converse was true, you must have reason to believe that physiological aerosol creation during breathing, speech, singing, coughing and/or sneezing uniquely results in immediate (presumably mechanical?) viricidal action. No evidence is presented for this hypothesis, and on the basis of universally applicable physical laws, it is impossible.

Extending this thought process, since WHO IPC Scientific Brief (July 2020) authors (including, I note, co-author TJ on this present manuscript) consider SARS-CoV-2 to be transmitted via closerange respiratory droplets, following the logic presented above, for aerosols released from COVID19 patients to be non-infectious, the only mechanism by which SARS-CoV-2 released on respiratory droplets ( $>5-10 \mu \mathrm{m}$ diameter as per WHO criteria) to be infectious, is for SARS-CoV-2 visions to be possessed with the ability to simultaneously measure and move between liberated respiratory particles to ensure that only those $>\mathbf{5 - 1 0} \mu \mathrm{m}$ diameter contain live SARS-CoV-2. Clearly, this is fantasy, since it also [logically] implies that SARS-CoV-2 is sentient and is aware of the current WHO convention for dichotomising respiratory particle size.

Secondly, excluding animal models of transmission not only goes against methods used by Wells and Riley towards the original proof that TB transmission occurs via the airborne route, but suggests that methods employing animal models of infection within strictly controlled environmental conditions are of no use towards understanding human-to-human transmission. It is my contention that - for example - the experiments of Kutter et al. (2021) using ferrets represent a very important contribution to our understanding, providing 'experimental evidence of robust transmission of SARS-COV-2 via the air $^{3}$.

I hope you are able to appreciate the important possible harms in excluding such lines of research towards 'understanding the objective nature of reality', and that you are able to provide major revisions to this present manuscript to include all relevant data, as described. Thank you.

5. From this same review article (your ref 4), table 2 states the known transmission routes of SARSCoV (Coronaviridae) as contact, droplet \& aerosol.

As I am sure you are aware, the WHO Ebola 2014 IPC guideline states 'scientists are unaware of any 
virus that has dramatically changed its mode of transmission'. So, in light of what is already known about human-to-human Coronaviridae transmission and the potential harms in failing to adequately mitigate every transmission route of SARS-CoV-2, I am curious as to why any infectious disease specialist or team of scientists investigating viral transmission would seek to 'secondguess' the inevitability of its [SARS-CoV-2] airborne transmission? This requires explanation please. Thank you.

6. Following the logic of point (3), your table 3 cannot be interpreted since objectively defined descriptions of 'Quality of included studies' is not provided.

I would be grateful if this analysis of study 'quality' could be updated in line with my suggestion of adopting objective 'quality definitions' above, please. Thank you.

Finally, I do not think it would be appropriate - and I don't want to risk wasting your time in reading yet further comments - for me to undertake any further point-by-point discussion/review of the conclusions which you have drawn from your chosen methods, since it is my contention that your chosen methods are so importantly flawed that the present manuscript should be completely re-written using methods with greater scientific validity, and including the whole range of available data towards SARS-CoV-2 transmission, as described. I hope this seems reasonable.

Many thanks again for providing me with the opportunity to provide peer review. This is a hugely important topic and I sincerely hope you can use comments raised during this process to improve the quality of this manuscript.

\section{References}

1. Tellier R: Aerosol transmission of influenza A virus: a review of new studies.J $R$ Soc Interface. 2009; 6 Suppl 6: S783-90 PubMed Abstract | Publisher Full Text

2. van Doremalen N, Bushmaker T, Morris D, Holbrook M, et al.: Aerosol and Surface Stability of SARS-CoV-2 as Compared with SARS-CoV-1. New England Journal of Medicine. 2020; 382 (16): 15641567 Publisher Full Text

3. Kutter J, de Meulder D, Bestebroer T, Lexmond P, et al.: SARS-CoV and SARS-CoV-2 are transmitted through the air between ferrets over more than one meter distance. Nature Communications. 2021; 12 (1). Publisher Full Text

\section{Are the rationale for, and objectives of, the Systematic Review clearly stated?}

Yes

Are sufficient details of the methods and analysis provided to allow replication by others? No

\section{Is the statistical analysis and its interpretation appropriate?}

Not applicable

Are the conclusions drawn adequately supported by the results presented in the review? No

Competing Interests: No competing interests were disclosed. 
Reviewer Expertise: My regular daytime job since 2009 has been as Consultant Cardiologist and Electrophysiologist - perhaps an unlikely job title for anyone reviewing this manuscript. However, as MedRxiv Affiliate since June 2019, I have been exposed to and performing 'release review' of a constant stream of early published works on SARS-CoV-2 - something which has catalysed my interest in this field. I am also experienced in assessing the validity of experimental methods chosen (please see my recent peer reviewed publications and/or preprints) and believe my background allows me to approach this topic without risk of anchoring bias towards one or other mode of respiratory viral transmission. My interest in this area can be further affirmed by evidence of my 'peer review' of the WHO SARS-CoV-2 IPC Scientific Briefing July 2020, assessing the validity of the chosen references *against* airborne transmission of SARS-CoV-2 (my pinned tweet @DRTomlinsonEP). I mention this to illustrate the breadth and depth of my reading and background on this subject, which may otherwise be assumed to be insufficient for someone in my professional role. I hope this is acceptable and that you are able to consider my comments constructively - since this is my intention. Thank you.

\section{I confirm that I have read this submission and believe that I have an appropriate level of expertise to state that I do not consider it to be of an acceptable scientific standard, for reasons outlined above.}

Author Response 25 Aug 2021

Carl Carl, University of Oxford, UK

Peer reviewers' comments

Authors' responses

\section{Peer Reviewer \#1}

Dear Professor Heneghan and team,

I would firstly like to congratulate you for publishing this systematic review on an open access site and for inviting comments. I am grateful for being given the opportunity to respond and to provide peer review. I hope you will consider the points I raise to be in the spirit of the best principles of scientific discourse - i.e., having a focus on methodology and without bias. I also hope that you and your team are open to performing major revisions to your manuscript, after consideration of all comments I provide below, and the other forms of feedback received through open access disclosure of this manuscript. Thank you.

\section{Response: Thank you.}

1. Page 4: 'A collection of particles (liquid or solid) ranging in size from $0.001 \mu \mathrm{m}$ to over $100 \mathrm{~mm}$ suspended in a gas defines an aerosol.'

You have made a typographical error here (easily done!), since aerosols - 'suspensions in air (or a gas) of solid or liquid particles small enough that they will remain airborne for a prolonged period of time because of their low settling velocity' (Tellier R, 2009 ${ }^{1}$ ) - are 
typically stated as being $<100 \mu \mathrm{m}$ diameter, not $\mathrm{mm}$. In addition, the definition of an aerosol typically includes reference to the time over which such particles may remain suspended in the air: would you consider adding this to the definition used in this present manuscript, please? For example, your methods document uses this wording, which is rather more complete in this respect: 'Respiratory droplets $<5 \mu \mathrm{m}$ in diameter are referred to as droplet nuclei or aerosols. Airborne transmission is the spread of an infectious agent caused by the dissemination of aerosols that remain infectious when suspended in air over long distances and time.' Thank you.

\section{Response: We have revised the definition.}

"There are varied definitions of aerosols in the published literature. An aerosol is defined as a collection of particles (liquid or solid) with varying aerodynamic diameters, suspended in the air (gas) for a prolonged period of time. The size of the particles and the distance they may travel is highly variable and depends on many factors, (

https://www.ncbi.nlm.nih.gov/pmc/articles/PMC2843947/;

https://apps.who.int/iris/bitstream/handle/10665/112656/9789241507134_eng.pdf;jsessionid=41AA684FB64

)"Consider to add this reference Xie X, Li Y, Chwang AT, Ho PL, Seto WH. How far droplets can move in indoor environments--revisiting the Wells evaporation-falling curve. Indoor Air. 2007 Jun;17(3):211-25. doi: 10.1111/j.1600-0668.2007.00469.x. PMID: 17542834

2. Paragraph 2 of your introduction contains two sentences with $55 \%$ match to the abstract of Kutter et al. (2018) - your reference 4.

This is evidence of presumably accidental plagiarism. The wording should be modified to remedy this please. Thank you.

\section{Response: We have revised the wording.}

"Transmission via droplets and aerosols in specific settings or situations may potentiate the spread of some viruses in humans, resulting in disease outbreaks that are difficult to manage. The results of several studies investigating human-to-human virus transmission have been largely inconclusive, and the evidence to inform such transmission in experimental studies is often not available."

3. Appendix 7 outlines chosen methodology for excluding studies. Phrases including words such as 'adequately', 'sufficient' and 'clearly defined' are used yet without objective definition provided, introducing the possibility of selection bias.

I would be grateful if you could provide such methodological points in objectively definable terms, please, thereby permitting a more appropriate description as to why each of these studies was ineligible for inclusion. Thank you.

Response: There is no Appendix 7 in the submission. However, see the response to comment 6 below where we expand on the methods used to assess reporting quality.

4. Thank you for providing a link to the 'Protocol for a living evidence review (Version 3: 1 
December 2020)'. Under 'Study inclusion and exclusion' is stated: 'Eligible studies should include sampling for the detection of SARs-CoV-2 in the population or the environment on any potential mode of transmission, including droplet, airborne, fomite, orofecal, bloodborne, vertical or other. Studies can be observational including case series, ecological, or prospective; or interventional including randomised trials and clinical reports, outbreak reports, case-control studies, experimental studies, non-predictive modelling. Studies should include sampling for the detection of SARs-CoV-2.'

Given this description of your intended methods, I am surprised that the methods for the present manuscript state: 'We included field studies that included airborne sampling for SARsCoV-2 in the population or the environment. Tronically, table 3 of Kutter et al. (your ref 4 ) is highly relevant to this important methodological point, since these authors describe the pros and cons of various methods to determine respiratory virus transmission. The cons of air sampling are noted: technical difficulty and possibly only circumstantial level evidence. However, these authors provide a list of further methods usefully employed including virus stability, outbreak (household or hospital) reports, aircraft outbreaks, non-pharmaceutical intervention, experimental infection, air tracer studies and computational modelling / simulation. Each method has its pros and cons, but it is my contention that restricting your present analyses to studies which 'included airborne sampling' excludes a large body of data which has been the foundation of investigations towards establishing routes of transmission of respiratory viruses amongst humans. Indeed, if your present methods were applied to measles, one would have to conclude that measles is not transmitted via the airborne route since live virus has never been successfully cultured from air samples. Therefore, and in line with this accepted and referenced practice within the field of infectious diseases, it is my contention that your present manuscript should include data from all suitably rigorous* experimental resources and outbreak reports listed here and as described by Kutter et al. Thank you.

[*Please forgive my use of a subjective term here: wording would be usefully informed by your response to point (3) I raise, above.]

In case this suggestion seems rather 'obtuse', I would like to draw upon two examples of excluding studies purely on the basis of their laboratory setting and the impact this may have on the validity of any such transmission review.

Firstly, the experiments of van Doremalen et al. (2020) ${ }^{2}$, in my opinion, represent a particularly valuable contribution towards understanding the possibility of airborne transmission of SARS-CoV-2.

\section{Van Doremalen outline methods:}

'Virus stability in aerosols was determined as described previously at $65 \%$ relative humidity $(R H)$ and $21-23^{\circ} \mathrm{C}$ (Fischer et al., 2016). In short, aerosols $(<5 \mu \mathrm{m})$ containing HCoV-19

(105.25 TCID50/mL) or SARS-CoV-1 (106.75-7 TCID50/mL) were generated using a 3-jet Collison nebulizer and fed into a Goldberg drum to create an aerosolized environment. Aerosols were maintained in the Goldberg drum and samples were collected at 0, 30, 60, 120 and 180 minutes post-aerosolization on a $47 \mathrm{~mm}$ gelatin filter (Sartorius). Filters were dissolved in $10 \mathrm{~mL}$ of DMEM containing 10\% FBS. Three replicate experiments were performed.' 
"Viable virus in all surface and aerosol samples was quantified by end-point titration on Vero E6 cells as described previously (van Doremalen et al., 2013).'

\section{Results (extract):}

'SARS-CoV-2 remained viable in aerosols throughout the duration of our experiment (3 hours), with a reduction in infectious titer from $10^{3.5}$ to $10^{2.7} \mathrm{TCID}_{50}$ per liter of air. This reduction was similar to that observed with SARS-CoV-1, from $10^{4.3}$ to $10^{3.5}$ TCID $_{50}$ per milliliter.'

\section{Conclusions (extract):}

'Our results indicate that aerosol and fomite transmission of SARS-COV-2 is plausible, since the virus can remain viable and infectious in aerosols for hours and on surfaces up to days (depending on the inoculum shed). These findings echo those with SARS-CoV-1, in which these forms of transmission were associated with nosocomial spread and super-spreading events, and they provide information for pandemic mitigation efforts.'

That this study was excluded from your review on the basis of its laboratory setting can only imply that you believe different physical laws might be in operation in a Goldberg drum compared to 'normal air'. However, it is clearly inconceivable that the air within a Goldberg drum using the methods described has unique virus lifespan-enhancing properties. Furthermore, it is biologically implausible that SARS-CoV-2 only ever achieves aerosol viability when these same aerosols are created using a Collison nebuliser. Indeed, if the converse was true, you must have reason to believe that physiological aerosol creation during breathing, speech, singing, coughing and/or sneezing uniquely results in immediate (presumably mechanical?) viricidal action. No evidence is presented for this hypothesis, and on the basis of universally applicable physical laws, it is impossible.

Extending this thought process, since WHO IPC Scientific Brief (July 2020) authors (including, I note, co-author TJ on this present manuscript) consider SARS-CoV-2 to be transmitted via close-range respiratory droplets, following the logic presented above, for aerosols released from COVID-19 patients to be non-infectious, the only mechanism by which SARS-CoV-2 released on respiratory droplets ( $>5-10 \mu \mathrm{m}$ diameter as per WHO criteria) to be infectious, is for SARS-CoV-2 visions to be possessed with the ability to simultaneously measure and move between liberated respiratory particles to ensure that only those $>\mathbf{5 - 1 0} \mu \mathrm{m}$ diameter contain live SARS-CoV-2. Clearly, this is fantasy, since it also [logically] implies that SARS$\mathrm{COV}-2$ is sentient and is aware of the current WHO convention for dichotomising respiratory particle size.

Secondly, excluding animal models of transmission not only goes against methods used by Wells and Riley towards the original proof that TB transmission occurs via the airborne route, but suggests that methods employing animal models of infection within strictly controlled environmental conditions are of no use towards understanding human-tohuman transmission. It is my contention that - for example - the experiments of Kutter et al. (2021) using ferrets represent a very important contribution to our understanding, providing 'experimental evidence of robust transmission of SARS-CoV-2 via the air' ${ }^{3}$.

I hope you are able to appreciate the important possible harms in excluding such lines of research towards 'understanding the objective nature of reality', and that you are able to 
provide major revisions to this present manuscript to include all relevant data, as described. Thank you.

Response:

We understand the reviewer's point involving the use of other methods to determine respiratory virus transmission. However, in our pre-specified "a priori" protocol, we planned to include sampling in the population or the environment. We do not discount the suggestion that SARS-CoV-2 can be sampled via other methods as the reviewer suggests. We have included this as a limitation of the study.

"We excluded study designs/settings that attempted to detect SARS-CoV-2 via other methods apart from air sampling, e.g., virus stability, outbreak reports, aircraft outbreaks, non-pharmaceutical intervention, experimental infection, air tracer studies and computational modelling/simulation"

Laboratory studies such as the one quoted provide insights into the stability of the virus in airborne suspensions but provide no insights into whether there exist ordinary biological mechanisms capable of generating such high-titer aerosols in the first place. The fact that one can put humans into orbit, doesn't mean it is an easily achieved or common task. It simply says humans can survive in orbit.

The inclusion of laboratory studies was not a part of our protocol but could be included as a part of a separate review but is outside the scope of our study.

The suggestion to include animal models or laboratory-based studies, in general, would not be appropriate. An animal review would be a separate review with a specific methodology. The Collaborative Approach to Meta-Analysis and Review of Animal Experimental Studies (CAMARADES) research group aims to address the gap in systematic review and meta-analysis in this area. See: CAMARADES | The University of Edinburgh.

We would like to point the classic 1964 Nature paper Survival of Measles Virus in Air | Nature (DE JONG, J., WINKLER, K. Survival of Measles Virus in Air. Nature 201, 1054-1055 (1964). https://doi.org/10.1038/2011054a0).

5. From this same review article (your ref 4), table 2 states the known transmission routes of SARS-CoV (Coronaviridae) as contact, droplet \& aerosol.

As I am sure you are aware, the WHO Ebola 2014 IPC guideline states 'scientists are unaware of any virus that has dramatically changed its mode of transmission'. So, in light of what is already known about human-to-human Coronaviridae transmission and the potential harms in failing to adequately mitigate every transmission route of SARS-CoV-2, I am curious as to why any infectious disease specialist or team of scientists investigating viral transmission would seek to 'second-guess' the inevitability of its [SARS-CoV-2] airborne transmission? This requires explanation please. Thank you.

Response:

We do consider a peer review seriously and do not seek to second-guess any 
conclusion but prefer to examine the evidence base in a rigorous manner. We have published over a hundred (100) systematic reviews and synthesize the evidence objectively in both this and a previous pandemic (see as an example: Neuraminidase inhibitors for preventing and treating influenza in adults and children Version published: 10 April 2014 Version history https://doi.org/10.1002/14651858.CD008965.pub4).

We analysed as in our previous work the published evidence to the date specified. We set out to determine whether SARS-CoV-2 could be detected in air samples. We have stated in our conclusion that the lack of positive samples does not rule-out airborne transmission and have tried to be as objective and open as possible but maintaining a rigorous evidence based approach.

The citation "WHO Ebola 2014 IPC guideline" may have been quoted out of context. Coronaviruses exhibit a variety of infection modes (respiratory, enteric, systemic), but if one looks beyond humans the disease is most commonly enteric in nature [see Saif (2004) Rev. sci. tech. Off. int. Epiz., 23 (2), 643-660]. The human respiratory strain OC-43 may have originated as a bovine enteric coronavirus. This is the reason why there has been so much interest in trying to detect and retrieve the SARS-CoV-2 from fecal specimens.

6. Following the logic of point (3), your table 3 cannot be interpreted since objectively defined descriptions of 'Quality of included studies' is not provided.

I would be grateful if this analysis of study 'quality' could be updated in line with my suggestion of adopting objective 'quality definitions' above, please. Thank you.

Response: Thank you. We have expanded the section on the methods used to assess the quality of reporting.

"We assessed quality using a modified QUADAS 2 risk of bias tool, ${ }^{\circ}$. We simplified the tool as the included studies were not designed as primary diagnostic accuracy studies and the quality of transmission studies is known to be low ${ }^{9}$. We gave particular importance to the description of methods for air sampling and the reporting of sufficient detail to enable replication of the study. We examined the following domains: (i) Source population - did the study authors adequately describe the source population? E.g. setting, severity of SARSCoV-2, baseline demographics including concurrent respiratory infections or other comorbidities, distance between study subjects; (ii) Methods - did the study authors sufficiently describe the methods used to enable replication of the study? E.g. methods used for diagnosing SARS-CoV-2 in patients, procedure used for air sampling, time-point for sampling, number of samples per site, cycle thresholds, culture methods, airflow/ventilation settings, humidity; (iii) Sample sources - did the authors clearly describe the sources for the air samples? What was the volume of air in each sample? Was the period of sampling similar across various sites? (iv) Outcome reporting - was the reporting of the results consistent with the study outcomes? Was the analysis of the results appropriate - e.g., interval and time-point for testing study participants for potential transmission; (v) Follow-up - was the pattern and number of air samples sufficient to 
demonstrate airborne transmission - e.g. repeat sampling, serial sampling?" The risk of bias for each domain was rated "low", "moderate" or "high" depending on the adequacy of reporting. One reviewer (CJH) assessed the risk of bias while a second author (EAS) independently verified the risk of bias. Any disagreements were resolved through discussion. Where a consensus could not be reached, a third reviewer (IJO) arbitrated."

Finally, I do not think it would be appropriate - and I don't want to risk wasting your time in reading yet further comments - for me to undertake any further point-by-point discussion/review of the conclusions which you have drawn from your chosen methods, since it is my contention that your chosen methods are so importantly flawed that the present manuscript should be completely re-written using methods with greater scientific validity, and including the whole range of available data towards SARS-CoV-2 transmission, as described. I hope this seems reasonable.

Response: We already have a published protocol that has been used to conduct our series of systematic reviews of studies investigating transmission dynamics of COVID19. However, our research is ongoing, the quality of the evidence and methods have changed over time and we make necessary adjustments to improve the robustness of the evidence as more studies (and evidence) become available (and examined). We are in contact with several original authors to clarify and update the methods.

Many thanks again for providing me with the opportunity to provide peer review. This is a hugely important topic and I sincerely hope you can use comments raised during this process to improve the quality of this manuscript.

Response:

Thanks. We have made several revisions to improve the quality of the manuscript.

Competing Interests: No competing interests were disclosed.

\section{Comments on this article}

\section{Version 1}

Reader Comment 18 May 2021

Raymond Tellier, McGill University, Montreal, Canada

Regarding the review in Heneghan et al. of Lednicky 2020a [1], which reported successful isolation in cell culture of SARS-CoV-2 from aerosol samples: Heneghan et al. take issues with the following:

1) No plaque assays was performed to estimate the concentration of viable viruses in the air due to shortage of some reagents, and a $\mathrm{TCID}_{50}$ based assay was performed instead. 
2) The cytopathic effect (CPE) was observed 6 to 11 days post inoculation.

3) No serial subcultures were done.

4) Infection of susceptible animals with cultured isolates was not performed.

5) There was no attempt to demonstrate a gradient effect by collecting aerosol samples at different distances from the source patient.

These criticisms appear very unconvincing.

1) Infectious titration by plaque assay typically requires a soft agar overlay; I would speculate that soft agar was the reagent unavailable as there is a shortage of several agarose products. At any rate there is nothing wrong with an infectious titration done by the TCID method, which is a standard and well established method in virology and indeed essentially equivalent to the plaque assay for viruses that produce plaques (one TCID $_{50}$ is approximately 0.69 plaque forming unit [PFU ]). We note that many other authors have used TCID-based titration for SASR-CoV-2 (e.g., [2]).

2) "With the exception of a few slower-growing viruses such as CMV, or when viruses are present at very low titers, the time to detection by traditional tube culture method is generally between 1 and 7 days of inoculation " [3].

As such, observing CPE 6 to 11 days following inoculation of a low viral load sample is therefore not unexpected. Other authors have used an observation period of 14 days for CPE when attempting to culture SARS-CoV-2 from samples with a very low viral load [4]. We would also note that although the complete CPE with rounding and detachment of cells took 6 to 11 days, early CPE foci with vacuolisation were already noted by 4 to 6 days [1].

3) The implied requirement for serial passage looks very much like an attempt to move the goalpost for acceptance of the existence of infectious SARS-CoV-2 viruses in aerosols. If the isolate would have been passage $N$ times, would there have been a request to passage it $(N+1)$ times?

Primary isolates from clinical samples are not laboratory adapted strains; they typically require specific mutations to adapt to the cell lines and when dealing with a low viral load sample the adaptation and the serial passage may or may not be successful; this does not negate the reality of infectious viruses being present in the sample. It has been reported that SARS-CoV-2 undergo adaptation in Vero E6 cells for at least 5-6 passages, with an increasing viral titer, acquisition of a large plaque phenotype and deletions in the furin cleavage site $[5,6]$.

4) Likewise, the implied requirement for successful animal infection with isolates recovered from air samples looks like another attempt to move the goalpost, and is especially surprising given that, as noted by the Reviewer \#1, Heneghan et al. did not include in their review animal transmission studies.

5) Why would the demonstration of a spatial gradient be considered essential? To be sure a greater concentration of aerosols near the source is to be expected but the steepness of the gradient 
would be modulated by the specific ventilation characteristics of the room. There would be also stochastic effects since an essential property of aerosol is that they will disperse randomly, not uniformly [7]. But in the end the important result is the demonstration of infectious viruses in aerosol particles.

We find all of the above disquieting in a review that aspires to be seen as authoritative, as it strongly suggests a lack of familiarity with the methods of Clinical Virology and the problems involved in culturing viruses present in very low viral load in clinical samples.

One may ask, of what benefit can it be to have a review of a very large number of published studies if one cannot trust that the studies have been summarized accurately and knowledgeably evaluated?

Raymond Tellier McGill University Julian W. Tang University of Leicester

\section{References:}

[1] Lednicky JA et al., Viable SARS-CoV-2 in the air of a hospital room with COVID-19 patients. Int J Infect Dis. 2020 Nov; 100:476-482.

[2] Harcourt J, et al., Severe Acute Respiratory Syndrome Coronavirus 2 from Patient with Coronavirus Disease, United States. Emerg Infect Dis. 2020;26(6):1266-1273.

[3] Capraro GA, Ginocchio CC; Reagents, Stains, Media and Cell Cultures: Virology. Chapter 82 in Manual of Clinical Microbiology $12^{\text {th }}$ ed. Carroll KC, Pfaller ME eds., ASM Press 2019 Washington DC.

[4] Singanayagam A et al., Duration of infectiousness and correlation with RT-PCR cycle threshold values in cases of COVID-19, England, January to May 2020. Euro Surveill. 2020;25(32):pii=2001483.

[5] Ogando NS et al. SARS-Coronavirus-2 replication in Vero E6 cells: replication kinetics, rapid adaptation and cytopathology. J Gen Virol 2020; 101: 925-940

[6] Klimstra WB et al. SARS-CoV-2 growth, furin-cleavage-site adaptation and neutralization using serum from acutely infected hospitalized Covid-19 patients. J Gen Virol 2020; 101: 1156-1169

[7] Riley RL, O'Grady F. Airborne Infection, Transmission and Control. MacMillan New York 1961

Competing Interests: No competing interests were disclosed.

Reader Comment 14 May 2021

Jose-Luis Jimenez, University of Colorado-Boulder, USA

Heneghan et al's paper is not, as it claims, a systematic review on the role of airborne transmission 
for SARS-CoV-2 (Heneghan et al. 2021). The mismatch between the paper's title, scope, methodology and conclusions could potentially misinform global policy and cost many lives.

The authors, who do not appear to have extensive (or perhaps any?) empirical experience in sampling viruses from the air, judge all the studies they reviewed to be of "low quality." Aerosol scientists would not reach the same conclusions. Indeed, a study of viable influenza virus released in aerosol particles during coughing and breathing (Lindsley et al. 2016) illustrates a number of quality criteria which a reviewer with expertise in aerosol science would expect of an empirical study in the field, namely the use of a well-characterized sampling system, detailed description of the sampling medium, careful accounting of collection efficiency as a function of particle size, sample replication, and purging to prevent cross-contamination. Heneghan et al's technocratic application of a 'risk of bias tool', QUADAS2, that was developed in a completely different discipline (clinical epidemiology) for assessing studies of an entirely different kind (diagnostic accuracy studies) has led these authors to misclassify many excellent studies. This is a troubling example of what has been termed "epistemological trespassing," and could have been avoided had the review team included an expert from the relevant academic field. Indeed, we are surprised that the World Health Organisation did not require some minimum level of topic expertise when commissioning the review.

A comprehensive review on the question of airborne transmission would need to include a much wider range of types of evidence. Importantly, airborne transmission of other diseases was accepted mainly on the basis of types of evidence not included in the Heneghan review, such as:

- Tuberculosis: animal studies (Riley et al. 1962)

- Measles: efficacy of UV disinfection (Wells 1943) and superspreading events with longdistance transmission (e.g. Bloch et al. 1985)

- Chickenpox: superspreading events (Leclair et al. 1980)

The type of evidence reviewed by Heneghan et al., namely demonstrating the infectivity of pathogens captured from the air, has never been achieved, to our knowledge, for tuberculosis, measles, or chickenpox (Morawska and Milton 2020; Fennelly 2020). Therefore if a review of only this narrow type of evidence allows one to reach the conclusion that "The lack of recoverable viral culture samples of SARS-CoV-2 prevents firm conclusions over airborne transmission," as done in this paper, we must reach the same conclusion for tuberculosis, measles, and chickenpox. This would clearly be nonsensical. Heneghan et al. have thus applied a much higher standard of proof to SARS-CoV-2 than to other pathogens that are widely agreed to be airborne. There is no discussion in the Heneghan paper about why such a higher standard of evidence is needed only for SARS-CoV-2, and of why the other types of evidence that led to the acceptance of other diseases as airborne have not even been considered.

Indeed, the types of evidence that led to the acceptance of tuberculosis, smallpox, and measles as airborne are available for SARS-CoV-2:

- Animal studies showing airborne transmission (e.g. Kutter et al. 2021)

- Superspreading events that occur exclusively in poorly-ventilated indoor environments, and 
can be generally explained by airborne transmission but not large droplet or fomite transmission, (e.g. Lewis 2021 and references therein; Miller et al. 2021)

- Long distance transmission (e.g. Katelaris et al. 2021)

In addition, as recently summarized in a peer-reviewed commentary in The Lancet (Greenhalgh et al. 2021), there are multiple additional streams of evidence that are also not considered at all by Heneghan et al., and that also support airborne transmission of SARS-CoV-2. These include:

- Transmission is twenty times more frequent indoors than outdoors (Bulfone et al. 2021). This cannot be explained by large droplet transmission, but is readily explained by airborne transmission, due to much higher dispersion outdoors than indoors.

- Superspreading events appear to occur dominantly in poorly-ventilated indoor spaces. This has led e.g. WHO to recommend ventilation as a way to reduce transmission, including detailed guidelines (World Health Organization 2021). This again is easily explained by airborne transmission, but not by large droplets or fomites which are not substantially impacted by ventilation.

- Presymptomatic and oligosymptomatic transmission is known to occur Johansson et al. 2021), and may be an important reason why we are in such a difficult-to-control pandemic. Measurements show that people without cough produce few droplets but abundant aerosols, (Chen et al. 2020), favoring the airborne route of transmission for people without a cough.

- Nosocomial infections have been reported in several studies, including some showing genomic match, despite wearing of surgical masks and eye protection (Klompas, Baker, Griesbach, et al. 2021; Klompas, Baker, Rhee, et al. 2021; Goldberg et al. 2021).

- SARS-CoV-2 virus material has been measured (by PCR) after sampling ducts and filters in a hospital building (Nissen et al. 2020). It could only have reached these locations as an aerosol.

Therefore, it is clear that there are many more lines of evidence to consider in order to ascertain the importance of airborne transmission of SARS-CoV-2. It is well-known that viruses are fragile and they are easily damaged when sampling them from the air (Pan et al. 2017), leading to difficulties in detecting viable virus. Amounts of pathogens in air that scientists have so far failed to cultivate can still drive disease transmission, as exemplified by measles and tuberculosis. Studying only the narrow topic of cultivation of viruses from air samples is therefore likely to give a highly misleading picture of the relevant evidence base.

The authors also appear to expect that live virus should be detectable in all locations where COVID19 patients are present. However, it is clear that viral load is extremely variable both in time (He et al. 2020) and between people (Yang et al. 2021). Aerosol generation is also highly variable among different people (Asadi et al. 2019; Edwards et al. 2021). Measurements of viral load by PCR in exhaled breath showed 73\% of COVID-19 patients did not produce detectable virus in their breath, but $27 \%$ exhaled, on average, millions of virus copies an hour (Ma et al. 2020). The very high 
variability in the amount of exhaled virus may apply to other diseases, and perhaps explain cases of lack of infection with shared air, that were used to deny the airborne character of measles for 7 decades (Bloch et al. 1985). This variability in virus emission may be a key reason why some people transmit SARS-CoV-2 to lots of others, while others do not transmit to anyone (Sun et al. 2021; Endo et al. 2020). In addition, ventilation of indoor spaces varies substantially across different environments and will lead to very variable amounts of dilution of any exhaled virus across the studies. Given all of these considerations, a high variability in the amount of virus captured from the air is not just not surprising but expected, and it is not an argument against airborne transmission of SARS-CoV-2.

In summary, no conclusions can be made about the importance of airborne transmission from only this review, while excluding all the other lines of evidence. We caution against using the findings of this review to inform policy.

Prof. Jose L. Jimenez, Univ. of Colorado-Boulder

Prof. Trisha Greenhalgh, Univ. of Oxford

Prof. David Fisman, Univ. of Toronto

Prof. Linsey C. Marr, Virginia Tech

\section{References:}

Asadi, Sima, Anthony S. Wexler, Christopher D. Cappa, Santiago Barreda, Nicole M. Bouvier, and William D. Ristenpart. 2019. "Aerosol Emission and Superemission during Human Speech Increase with Voice Loudness." Scientific Reports 9 (1): 2348.

Bloch, A. B., W. A. Orenstein, W. M. Ewing, W. H. Spain, G. F. Mallison, K. L. Herrmann, and A. R. Hinman. 1985. "Measles Outbreak in a Pediatric Practice: Airborne Transmission in an Office Setting ." Pediatrics 75 (4): 676-83.

Bulfone, Tommaso Celeste, Mohsen Malekinejad, George W. Rutherford, and Nooshin Razani. 2021. "Outdoor Transmission of SARS-CoV-2 and Other Respiratory Viruses: A Systematic Review." The Journal of Infectious Diseases 223 (4): 550-61.

Chen, Wenzhao, Nan Zhang, Jianjian Wei, Hui-Ling Yen, and Yuguo Li. 2020. “Short-Range Airborne Route Dominates Exposure of Respiratory Infection during Close Contact." Building and Environment 176 (June): 106859.

Edwards, David A., Dennis Ausiello, Jonathan Salzman, Tom Devlin, Robert Langer, Brandon J. Beddingfield, Alyssa C. Fears, et al. 2021. "Exhaled Aerosol Increases with COVID-19 Infection, Age, and Obesity." Proceedings of the National Academy of Sciences of the United States of America 118 (8).

Endo A, Centre for the Mathematical Modelling of Infectious Diseases COVID-19 Working Group, Abbott $\mathrm{S}$ et al. Estimating the overdispersion in COVID-19 transmission using outbreak sizes outside China [version 3; peer review: 2 approved]. Wellcome Open Res 2020, 5:67 
Fennelly, Kevin P. 2020. "Particle Sizes of Infectious Aerosols: Implications for Infection Control.” The Lancet. Respiratory Medicine 8 (9): 914-24.

Goldberg, Lotem, Yoel Levinsky, Nufar Marcus, Vered Hoffer, Michal Gafner, Shai Hadas, Sraya Kraus, Meirav Mor, and Oded Scheuerman. 2021. "SARS-CoV-2 Infection among Healthcare Workers despite the Use of Surgical Masks and Physical Distancing - the Role of Airborne Transmission." Open Forum Infectious Diseases, January.

Greenhalgh, Trisha, Jose L. Jimenez, Kimberly A. Prather, Zeynep Tufekci, David Fisman, and Robert Schooley. 2021. "Ten Scientific Reasons in Support of Airborne Transmission of SARS-CoV-2." The Lancet, April.

Heneghan CJ, Spencer EA, Brassey J et al. SARS-CoV-2 and the role of airborne transmission: a systematic review [version 1; peer review: 1 approved with reservations, 2 not approved].

F1000Research 2021, 10:232

He, Xi, Eric H. Y. Lau, Peng Wu, Xilong Deng, Jian Wang, Xinxin Hao, Yiu Chung Lau, et al. 2020. “ Temporal Dynamics in Viral Shedding and Transmissibility of COVID-19." Nature Medicine 26 (5): 672-75.

Johansson, Michael A., Talia M. Quandelacy, Sarah Kada, Pragati Venkata Prasad, Molly Steele, John T. Brooks, Rachel B. Slayton, Matthew Biggerstaff, and Jay C. Butler. 2021. "SARS-CoV-2

Transmission From People Without COVID-19 Symptoms." JAMA Network Open 4 (1): e2035057.

Katelaris, Anthea L., Jessica Wells, Penelope Clark, Sophie Norton, Rebecca Rockett, Alicia Arnott, Vitali Sintchenko, Stephen Corbett, and Shopna K. Bag. 2021. “Epidemiologic Evidence for Airborne Transmission of SARS-CoV-2 during Church Singing, Australia, 2020." Emerging Infectious Diseases 27 (6).

Klompas, Michael, Meghan A. Baker, Diane Griesbach, Robert Tucker, Glen R. Gallagher, Andrew S. Lang, Timelia Fink, et al. 2021. "Transmission of SARS-CoV-2 from Asymptomatic and Presymptomatic Individuals in Healthcare Settings despite Medical Masks and Eye Protection." Clinical Infectious Diseases, March.

Klompas, Michael, Meghan A. Baker, Chanu Rhee, Robert Tucker, Karen Fiumara, Diane Griesbach, Carin Bennett-Rizzo, et al. 2021. "A SARS-CoV-2 Cluster in an Acute Care Hospital." Annals of Internal Medicine, February.

Kutter, Jasmin S., Dennis de Meulder, Theo M. Bestebroer, Pascal Lexmond, Ard Mulders, Mathilde Richard, Ron A. M. Fouchier, and Sander Herfst. 2021. "SARS-CoV and SARS-CoV-2 Are Transmitted through the Air between Ferrets over More than One Meter Distance." Nature Communications 12 (1): 1653.

Leclair, J. M., J. A. Zaia, M. J. Levin, R. G. Congdon, and D. A. Goldmann. 1980. “Airborne Transmission of Chickenpox in a Hospital." The New England Journal of Medicine 302 (8): 450-53. 
Lewis, Dyani. 2021. "Superspreading Drives the COVID Pandemic - and Could Help to Tame It." Nature 590 (7847): 544-46.

Lindsley, William G., Francoise M. Blachere, Donald H. Beezhold, Robert E. Thewlis, Bahar Noorbakhsh, Sreekumar Othumpangat, William T. Goldsmith, et al. 2016. "Viable Influenza A Virus in Airborne Particles Expelled during Coughs versus Exhalations." Influenza and Other Respiratory Viruses 10 (5): 404-13.

Ma, Jianxin, Xiao Qi, Haoxuan Chen, Xinyue Li, Zheng Zhang, Haibin Wang, Lingli Sun, et al. 2020. “ COVID-19 Patients in Earlier Stages Exhaled Millions of SARS-CoV-2 per Hour." Clinical Infectious Diseases: An Official Publication of the Infectious Diseases Society of America, August.

Miller, Shelly L., William W. Nazaroff, Jose L. Jimenez, Atze Boerstra, Giorgio Buonanno, Stephanie J. Dancer, Jarek Kurnitski, Linsey C. Marr, Lidia Morawska, and Catherine Noakes. 2021. "Transmission of SARS-CoV-2 by Inhalation of Respiratory Aerosol in the Skagit Valley Chorale Superspreading Event." Indoor Air 31 (2): 314-23.

Morawska, Lidia, and Donald K. Milton. 2020. "Reply to Chagla et al., and Thomas." Clinical Infectious Diseases: An Official Publication of the Infectious Diseases Society of America, August.

Nissen, Karolina, Janina Krambrich, Dario Akaberi, Tove Hoffman, Jiaxin Ling, Åke Lundkvist, Lennart Svensson, and Erik Salaneck. 2020. “Long-Distance Airborne Dispersal of SARS-CoV-2 in COVID-19 Wards." Scientific Reports 10 (1): 19589.

Pan, Maohua, Tania S. Bonny, Julia Loeb, Xiao Jiang, John A. Lednicky, Arantzazu Eiguren-Fernandez, Susanne Hering, Z. Hugh Fan, and Chang-Yu Wu. 2017. “Collection of Viable Aerosolized Influenza Virus and Other Respiratory Viruses in a Student Health Care Center through Water-Based Condensation Growth." mSphere 2 (5).

Riley, R. L., C. C. Mills, F. O'grady, L. U. Sultan, F. Wittstadt, and D. N. Shivpuri. 1962. “Infectiousness of Air from a Tuberculosis Ward. Ultraviolet Irradiation of Infected Air: Comparative Infectiousness of Different Patients." The American Review of Respiratory Disease 85 (April): 511-25.

Sun, Kaiyuan, Wei Wang, Lidong Gao, Yan Wang, Kaiwei Luo, Lingshuang Ren, Zhifei Zhan, et al. 2021. “Transmission Heterogeneities, Kinetics, and Controllability of SARS-CoV-2." Science 371 (6526).

Wells, W. F. 1943. "Air Disinfection in Day Schools." American Journal of Public Health and the Nation's Health 33 (12): 1436-43.

World Health Organization (WHO). 2021. “Roadmap to Improve and Ensure Good Indoor Ventilation in the Context of COVID-19." World Health Organization. March 1, 2021.

Yang, Qing, Tassa K. Saldi, Patrick K. Gonzales, Erika Lasda, Carolyn J. Decker, Kimngan L. Tat, Morgan R. Fink, et al. 2021. "Just 2\% of SARS-CoV-2-Positive Individuals Carry 90\% of the Virus Circulating in Communities." Proceedings of the National Academy of Sciences of the United States 
of America 118 (21).

Competing Interests: No competing interests

The benefits of publishing with F1000Research:

- Your article is published within days, with no editorial bias

- You can publish traditional articles, null/negative results, case reports, data notes and more

- The peer review process is transparent and collaborative

- Your article is indexed in PubMed after passing peer review

- Dedicated customer support at every stage

For pre-submission enquiries, contact research@f1000.com 